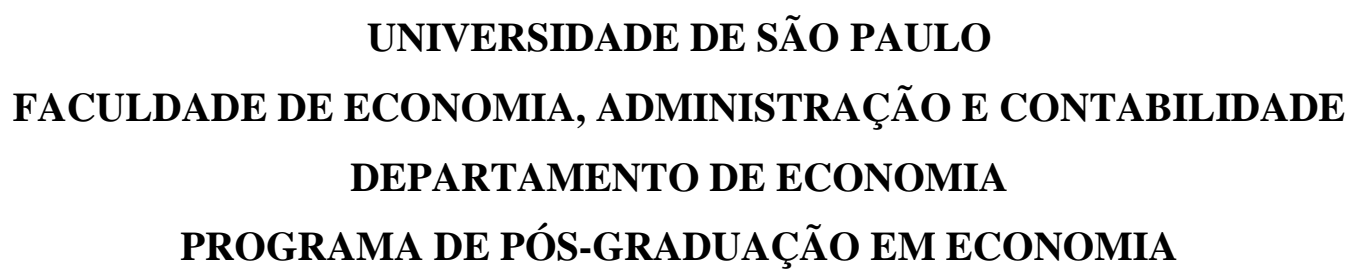

PROGRAMA DE PÓS-GRADUAÇÃO EM ECONOMIA

CONDIÇOES ATUARIAIS PARA A CONSTRUÇÃO DO FUNDO PREVIDENCIÁRIO FEDERAL - FUNPRESP

Gilmar Gonçalves Ferreira

Orientador: Prof. Dr. Hélio Nogueira da Cruz

SÃO PAULO

2008 
Profa. Dra. Suely Vilela

Reitora da Universidade de São Paulo

Prof. Dr. Carlos Roberto Azzoni

Diretor da Faculdade de Economia, Administração e Contabilidade

Prof. Dr. Joaquim José Martins Guilhoto

Chefe do Departamento de Economia

Prof. Dr. Dante Mendes Aldrighi

Coordenador do Programa de Pós-Graduação em Economia 
GILMAR GONÇALVES FERREIRA

\title{
CONDIÇOES ATUARIAIS PARA A CONSTRUÇÃO DO FUNDO PREVIDENCIÁRIO FEDERAL - FUNPRESP
}

\author{
Dissertação apresentada ao Departamento de \\ Economia da Faculdade de Economia, \\ Administração e Contabilidade da Universidade \\ de São Paulo como requisito parcial para a \\ obtenção do título de Mestre em Economia.
}

Orientador: Prof. Dr. Hélio Nogueira da Cruz

\section{SÃo PAULO}


FICHA CATALOGRÁFICA

Elaborada pela Seção de Processamento Técnico do SBD/FEA/USP

Ferreira, Gilmar Gonçalves

Condições atuariais para a construção do fundo

previdenciário federal - FUNPRESP / Gilmar

Gonçalves Ferreira . -- São Paulo, 2008.

$84 \mathrm{p}$.

Dissertação (Mestrado) - Universidade de São Paulo, 2008 Bibliografia

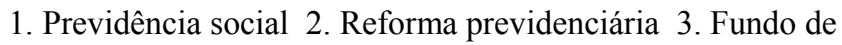
pensão I. Universidade de São Paulo. Faculdade de Economia, Administração e Contabilidade. II. Título.

CDD - 368.4 
À minha Família, minha mãe e meus irmãos, os grandes responsáveis pela concretização desse trabalho.

À meu pai, in memorian, de quem herdei, desde muito cedo, o gosto pelos livros. 


\section{AGRADECIMENTOS}

Em primeiro lugar a minha família, minha mãe e meus irmãos, pelo apoio e paciência comigo durante todo esse período de dedicação integral aos estudos.

Ao meu orientador, Hélio Nogueira, por sua disponibilidade, interesse acadêmico, confiança e atenção durante toda essa longa jornada.

Aos professores e funcionários tão prestativos e atenciosos durante todo esse tempo de FEA em especial as secretárias, Márcia e Dirce, e a Valéria da CPG.

Aos bons amigos que fiz dentre os pós-graduandos em economia da FEA/USP, da minha turma ou não, cujos nomes não mencionarei para não correr o risco de fazer injustiça a alguém, mas sem os quais seria muito mais difícil e penoso o percurso até o final desse trabalho.

Aos meus amigos de Guarulhos - em particular ao pessoal do objetivo, Maria, Roberto e Arthur, pela paciência que tiveram comigo durante os anos de cursinho.

Aos bhoemios - Tarcisio, Sandro, Juarez, Neto, Rodrigo, Zacha, Adolfo, Renato, Bruneto e Jura — amigos de todos os momentos e de longas datas, pela amizade e paciência que sempre tiveram comigo, grupo do qual me orgulho em fazer parte.

Aos amigos de graduação em particular ao Cristian Lima, Fernando Cavaça, João Paulo Faleiros, Elton Jony, Daniel Silva, Juliana, e Alan que sempre me acompanharam durante toda a graduação.

Aos amigos de "Concursos" Cop, Leandro, Ceccato e André que sempre tiveram muita paciência comigo durante esse período.

A todos que diretamente ou indiretamente, me ajudaram de alguma forma durante o mestrado. 
“O sistema de Seguridade Social brasileiro, criado na Constituição de 1988, tinha ambições escandinavas e recursos moçambicanos" Roberto Campos (1988) 


\section{RESUMO}

Este trabalho analisa as condições atuariais para criação do Fundo previdenciário federal (FUNPRESP) e como será o novo sistema previdenciário após o funcionamento desse Fundo que finalmente concluirá, em âmbito federal, as reformas iniciadas em 1998. A partir desse estudo concluímos que o novo sistema previdenciário, sistema misto, pagará benefícios menores para os servidores que ingressarem depois da criação do fundo quando comparados com os atuais servidores. Em razão disso os atuais servidores, analisando apenas os ganhos financeiros, não migrarão para o Fundo federal conforme é esperado pelo Governo. As mulheres receberão nesse novo sistema previdenciário benefícios menores em função do menor tempo de contribuição, expectativa de vida maior e menor taxa de crescimento salarial. Mas os grandes avanços com a criação do fundo serão o equilíbrio atuarial do sistema federal de previdência e o fim das grandes desigualdades entre esse sistema e o regime geral de previdência. A criação do Fundo fará com que os benefícios fiquem atrelados diretamente à contribuição de cada servidor, diferentemente do que ocorria antes quando os benefícios eram proporcionais à remuneração do servidor - até 2003 era equivalente a última remuneração e depois de 2003 é equivalente à média das $80 \%$ maiores remunerações. 


\begin{abstract}
The present work analyzes the actuarial conditions for the creation of the Brazilian Federal Social Security Fund (FUNPRESP) and how the new Social Security System will work after the effective functioning of the Fund. We could say that in the federal sphere it will finally finish off the reforms initiated in 1998. We conclude that the new Social Security System (called "mixed system") will provide lower payments to the beneficiaries who start to contribute after the creation of the Fund. In consequence, the current beneficiaries will not migrate to the new Federal Fund, as the government expects, because some simple analysis will make they conclude that they would incur into financial losses. Along with that, female beneficiaries will receive fewer benefits than men from that new Social Security System, basically for three reasons: a) their shorter time of contribution; b), their higher life expectancy; and c), the lower rate at which their payments actually grow.

We also conclude that the real advantages brought by the creation of the Fund are: a) the actuarial equilibrium of the Federal Social Security System, and b) the end of the huge inequalities between that system and the "general" Brazilian Social Security System (INSS). The creation of the Fund will link the benefits directly to the contribution of each servant, as opposed to when benefits were proportional to the servant's pay (equal to it until 2003, or equivalent to the average of the $80 \%$ highest salaries).
\end{abstract}




\section{Sumário}

Sumário ............................................................................................................................... 1

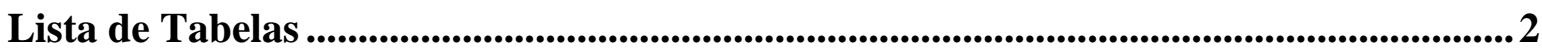

Lista de Gráficos.........................................................................................................................

1. Introdução ........................................................................................................................... 4

2. O Sistema Previdenciário.................................................................................................

2.1 Como Funcionam os Sistemas Previdenciários..................................................... 8

2.2. O sistema previdenciário Brasileiro …………….......................................... 9

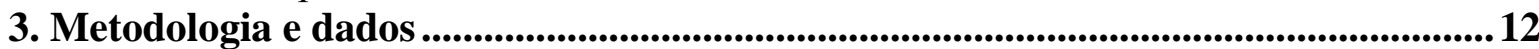

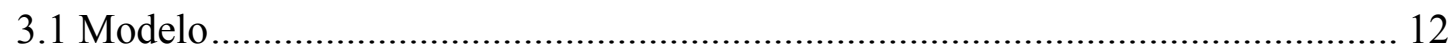

3.1.2 Fundo de Investimento ........................................................................... 14

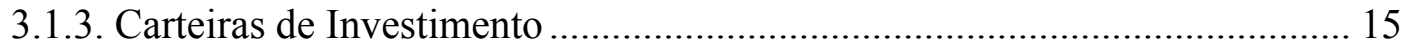

3.1.4. Implementação das Contas Pessoais de Aposentadoria ................................ 16

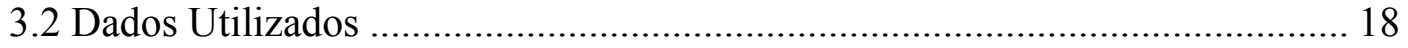

4. Obrigaçø̃es Previdenciárias ................................................................................................20

4.1. Principais Desdobramentos Previdenciários ...................................................... 20

4.2. Alternativas para o servidor que tem remuneração acima do piso previdenciário

4.3. Formulação Matemática dos benefícios pagos pelo RPPS.................................... 23

4.4. Aposentadoria Programada …………………………...................................... 24

4.5. Aposentadoria por Invalidez............................................................................. 26

4.6.1. Pensão do Servidor Ativo ……………………………........................... 29

4.6.2. Pensão do Servidor Ativo que Alcance a Aposentadoria Programada.......... 31

4.6.3. Pensão do Servidor Ativo que se Aposente por Invalidez ............................. 33

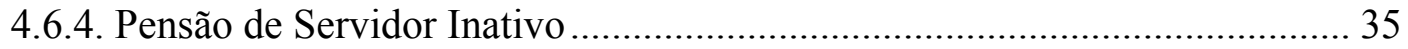

5. Estimação dos Fluxos Financeiros no Fundo ....................................................................39

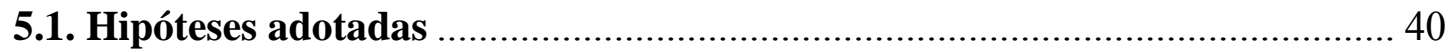

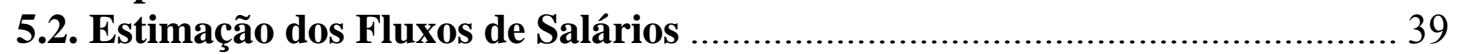

5.3. Tempo de Contribuição e Recebimento de Benefícios ..................................... 43

5.4. Contribuições para o Fundo Federal e Benefícios pagos pelo Fundo Federal

45

6. Principais resultados do sistema previdenciário federal após a criação do Fundo

Federal.

6.1. Benefícios e contribuições dos sistemas previdenciários.

6.2. Valores dos benefícios para os servidores de acordo com cenários adotados

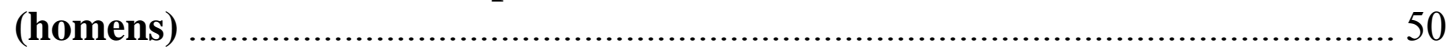

6.3. Valores dos benéficos para servidoras de acordo com os cenários adotados (mulheres).

7. Concluso os ............................................................................................................................ 63

Referências Bibliográficas: ........................................................................................................... 65

Anexos.............................................................................................................................69 


\section{Lista de Tabelas}

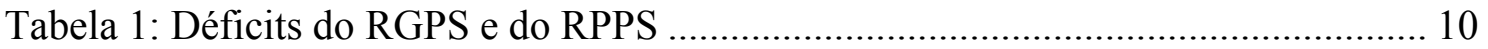

Tabela 2: Regime Próprio de Previdência dos servidores Públicos da União................ 21

Tabela 3: Fluxo de Aposentadoria Programada a Conceder ........................................ 25

Tabela 4: Fluxo de Aposentadoria Por Invalidez ........................................................ 27

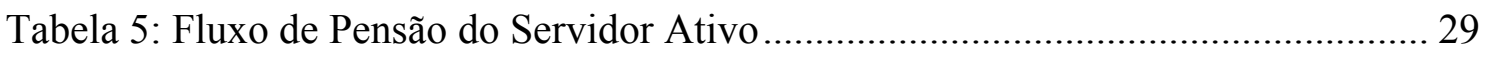

Tabela 6: Fluxo de Pensão do Servidor Ativo que Alcance Aposentadoria Programada

Tabela 7: Fluxo de Pensão do Servidor Ativo que se Aposente por Invalidez ............... 34

Tabela 8: Fluxo de Pensão do Inativo ................................................................................... 36

Tabela 9 :Regressão do logaritmo da renda no trabalho principal ................................ 42

Tabela 10: Idade de Ingresso, Aposentadoria, Expectativa de vida e Tempo de contribuição e Sobrevida para homens e mulheres respectivamente 


\section{Lista de Gráficos}

Gráfico 1 - Evolução do saldo da Conta Pessoal de Aposentadoria ............................... 18

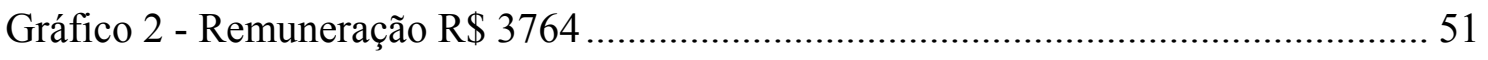

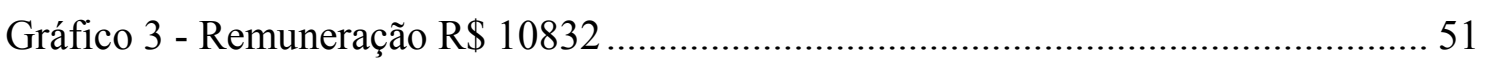

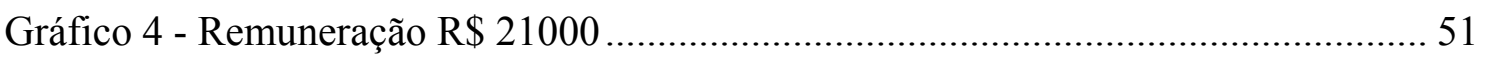

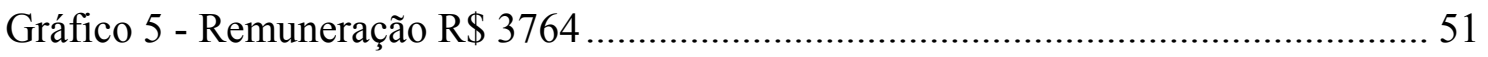

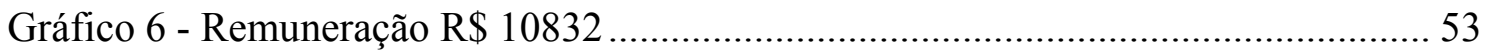

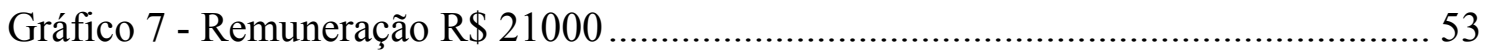

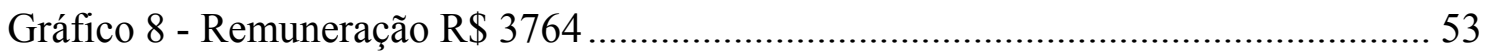

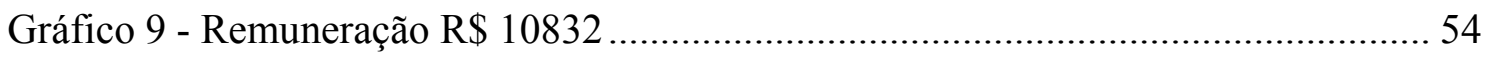

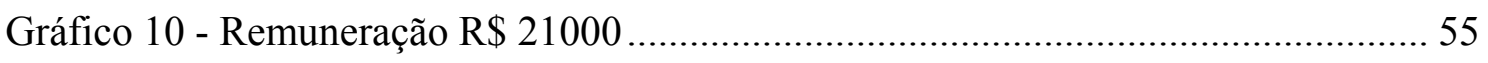

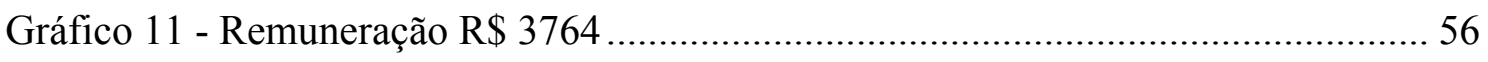

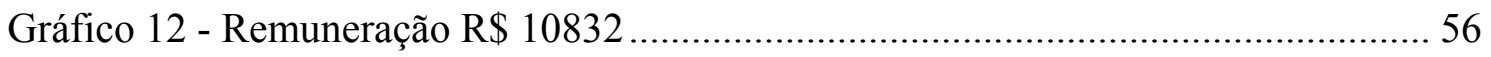

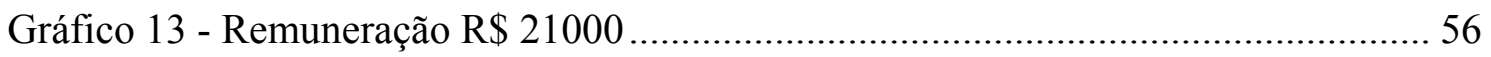

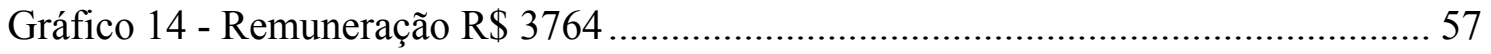

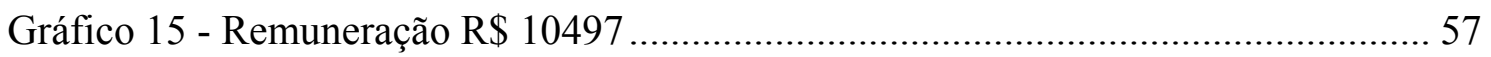

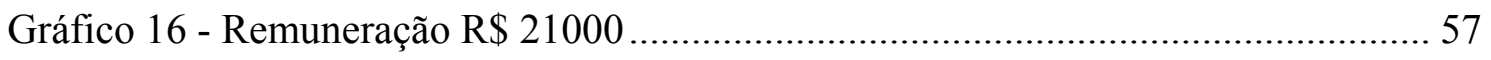

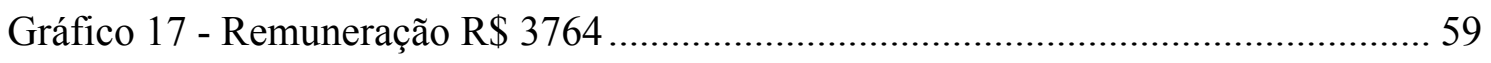

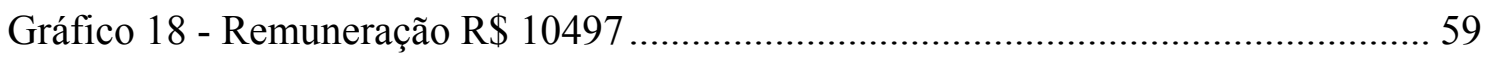

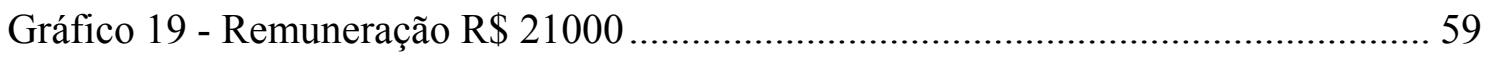

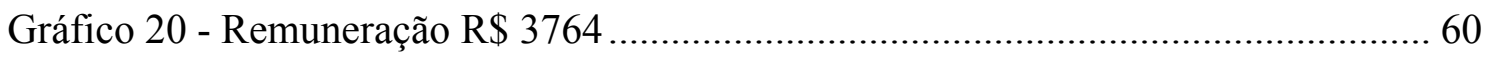

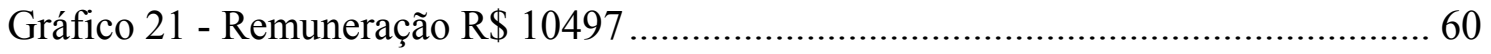

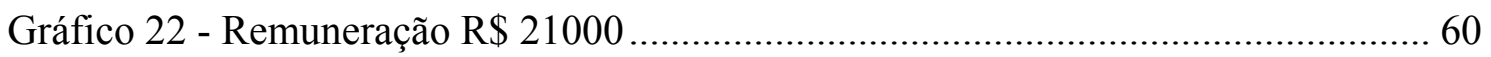

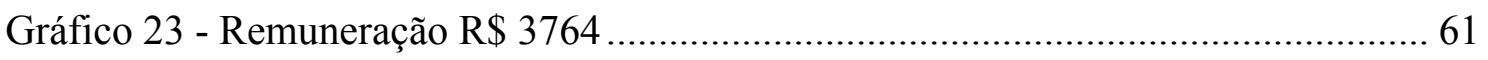

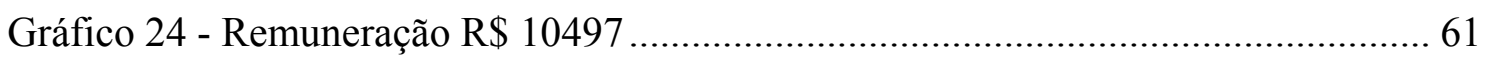

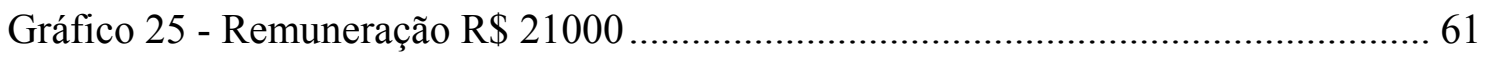




\section{Introdução}

O problema previdenciário no Brasil vem se agravando sensivelmente desde o início da década de noventa e assumiu proporções preocupantes nos últimos anos, tornando-se um dos problemas mais graves das finanças públicas do Brasil. A escalada dos déficits previdenciários, tanto do Regime Geral de Previdência Social (RGPS) quanto dos regimes próprios de previdência dos servidores (RPPSs), associados a um histórico quadro de desigualdades e diferenças de direitos e regras, notadamente nos RPPSs, fez esse tema ocupar uma posição de destaque na agenda político-econômica do país, impulsionando o ímpeto por reformas. As reformas materializaram-se em uma série de medidas adotadas pelo governo que ficaram conhecidas como "A Reforma da Previdência nos anos de 1998 e 2003" e que tiveram avanços significativos na direção de equilibrar o déficit. A Reforma de 1998, através da Emenda Constitucional No20 (EC No20), teve um impacto maior no RGPS, enquanto a reforma de 2003, através da EC $\mathrm{N}^{\mathrm{o}} 40$, atingiu basicamente os RPPSs.

Em relação ao regime dos servidores públicos um dos principais avanços foi o fim da integralidade e da paridade dos benefícios, um dos grandes agravantes do déficit da previdência. A integralidade garantia ao servidor aposentado a sua ultima remuneração, em alguns casos a remuneração do cargo imediatamente superior, como aposentadoria e a paridade garantia o mesmo valor da remuneração do servidor ativo para o aposentado, inclusive as gratificações. Essa regra foi eliminada, em âmbito federal, para os servidores que ingressaram após o ano de 2003. Em seu lugar o Governo criou outra forma de cálculo para essas aposentadorias. Nessa nova fórmula as aposentadorias serão equivalentes ao valor da média aritmética das $80 \%$ maiores remunerações e irá valer para os servidores que ingressaram após 2003 até a criação do Fundo Previdenciário.

O Fundo Previdenciário Federal (FUNPRESP), cujo projeto já foi enviado ao Congresso Nacional, consistirá de um fundo previdenciário para os servidores públicos federais das três esferas de poder: Executivo, Judiciário e Legislativo. Participarão desse Fundo, obrigatoriamente, os servidores que receberem remuneração acima do piso previdenciário, hoje o valor do piso é de $\mathrm{R} \$ 2.940 .00$, e tiverem ingressado na administração pública federal após a criação do Fundo e os servidores que entraram na administração pública federal antes da criação do Fundo e optarem por migrar para o Fundo. 
As contribuições previdenciárias para o Fundo serão realizadas pelos servidores que participarem do Fundo juntamente com a contrapartida do governo que deverá ser igual à contribuição do servidor. O Fundo pagará benefícios de acordo com o montante acumulado de recursos de cada servidor. Os servidores que ingressarem na administração Federal antes da criação do Fundo e tiverem migrado para o Fundo receberão, também, um abono especial ${ }^{1}$ que deverá compensar o menor tempo de contribuição e conseguintemente o beneficio menor que receberão.

A partir da criação do Fundo teremos então um sistema previdenciário misto. Os servidores que pertencerem ao Fundo receberão parte de seus benefícios do Fundo e parte, valor do piso previdenciário, do RPPS. Os servidores que não migrarem para o Fundo receberão seus benefícios do RPPS.

O sistema misto apresenta enormes vantagens para o Governo em relação ao sistema atual, sistema de repartição, tais como: a) menor distorção no sistema previdenciário, pois existe uma relação direta entre a contribuição e o valor do beneficio recebido; b) o sistema misto tende ao equilíbrio atuarial devido ao pagamento dos benefícios de acordo com os valores poupados; e c) o sistema misto irá gerar poupança na economia que poderá refletir em mais investimentos. Portanto, há urgência por parte do Governo Federal em aprovar o projeto para constituição do Fundo federal e finalmente concluir a reforma da previdência iniciada em 1998.

Os recentes estudos empíricos sobre a previdência social, de maneira geral, podem ser divididos em duas linhas de trabalhos (ZYLBERSTAJN, 2006). A primeira delas tem aspectos mais fiscalistas, ou seja, tem focado mais sobre o equilíbrio entre receitas e despesas e a sustentabilidade dos sistemas previdenciários. Os trabalhos clássicos nesta linha são Kotlikoff (1995), Feldstein e Samwick (2001), Smetters (1999) e Lee e Yamagata (2003), que centram sua atenção no esgotamento do Trust Fund da previdência dos EUA. Para o caso brasileiro, podemos citar os trabalhos de Schymura, Lannes e Perdigão (2000), que calculam o passivo previdenciário dos estados brasileiros, e Oliveira e Beltrão (2000) que calculam os impactos da Emenda

\footnotetext{
${ }^{1}$ A regra está descrita no anexo 3. O que se espera com esse beneficio é igualar os rendimentos dos servidores que ingressaram no Fundo e irão contribuir pelo período normal, 35 anos para homens e 30 anos para mulheres, com aqueles que contribuirão por um período menor, ou seja, aqueles que migraram para o Fundo.
} 
Constitucional $\mathrm{N}^{\mathrm{o}} 20$ sobre o déficit previdenciário, tanto do RGPS, quanto dos RPPSs. Mascarenhas, Oliveira e Caetano (2004) mostram que a EC 41 deve proporcionar no período 2004-2023 uma redução no déficit previdenciário, para os servidores do executivo e do judiciário, da ordem de R\$ 49 bilhões. Embora a reforma reduza o déficit, ainda assim não traz igualdade entre receitas e despesas, pois continuará existindo a necessidade de aportes elevados, superiores a R\$ 12 bilhões por ano. Giambiagi et alii (2004) fazem um diagnóstico bastante completo dos problemas da previdência social no Brasil. Os autores mostram a necessidade de mudar o sistema previdenciário, reduzindo privilégios e tornando-o mais equânime.

A segunda linha tem focalizado nas questões distributivas e de justiça social. Oliveira, Beltrão e Maniero (1997) calculam as alíquotas de contribuição atuarialmente justas, por gênero, escolaridade e tipo de benefício previdenciário. Mas o trabalho de Fernandes e Gremaud (2003) é o que mais se relaciona com esse trabalho. Eles calculam as alíquotas de contribuição necessárias ao equilíbrio atuarial para os servidores públicos, por gênero e nível de escolaridade, região e nível de poder, supondo-se as regras então dadas pela EC 20, e que essas se manteriam ao longo de toda a vida dos indivíduos. Os autores encontram uma elevada alíquota média, 73,19\%. Para os militares, a alíquota seria de pouco mais de $60 \%$. Já para os servidores civis, a alíquota seria de mais de $74 \%$.

É interessante notar que nenhum trabalho sobre previdência no Brasil busca entender os resultados previdenciários a partir da construção de um sistema previdenciário misto sistema de repartição e capitalização. Na literatura internacional temos o caso clássico de Feldstein (2001) que sugere a transição de um sistema de repartição para um sistema misto com a criação de um Fundo de Previdência. Portanto, esta dissertação torna-se pioneira ao descrever as condições e os resultados de um sistema previdenciário federal misto a partir da criação de um Fundo federal (FUNPRESP) no moldes do trabalho desenvolvido por Feldstein. Mais especificamente esse trabalho busca entender quais são as condições atuariais para a construção do Fundo Federal, fato que efetivamente concluirá as reformas iniciadas em 1998, e os resultados decorrentes. De forma mais direta ainda esse trabalho procura responder as seguintes questões, ainda em aberto: i) qual será o valor do beneficio pago, efetivamente, aos servidores a partir da alíquota máxima legal de contribuição do servidor/governo? ii) quais os valores dos benefícios 
sob alíquotas diferenciadas de acordo com a remuneração desse Fundo e com cenários diferentes de crescimento e taxas de juros?; iii) qual a melhor opção para o servidor, de acordo com os benefícios calculados: permanecer no atual sistema ou migrar para o Fundo? 


\section{O Sistema Previdenciário}

Dividiremos esse capitulo em duas seções. Na primeira descreveremos como funcionam os sistemas previdenciários, suas vantagens e desvantagens. Na segunda descreveremos o sistema previdenciário brasileiro.

\subsection{Como Funcionam os Sistemas Previdenciários}

Podemos classificar os sistemas previdenciários basicamente em três tipos, de acordo com suas formas de financiamento: sistema de repartição, sistema de capitalização e sistema misto - uma combinação do sistema de repartição e capitalização.

No sistema de repartição há um contrato social entre gerações sucessivas. A geração de trabalhadores atual paga os benefícios previdenciários da geração precedente com a expectativa de que as gerações futuras de trabalhadores paguem seus benefícios. O sistema mantém-se de forma que as contribuições da população ativa financiam os benefícios da população inativa. Logo, se a população tem uma massa maior de trabalhadores ativos em proporção a seus inativos, as gerações sucessivas serão beneficiadas com uma massa maior de contribuintes. Por outro lado, se a população tem baixas taxas de crescimento vegetativo e a força de trabalho envelhece, as gerações sucessivas terão uma massa menor de contribuintes e um número maior de beneficiários para serem financiados.

No sistema de capitalização, os trabalhadores contribuem para formação de uma poupança, que será o montante de benefícios ao qual irão receber. Os recursos são investidos em ativos existentes no mercado financeiro permitindo a capitalização desses recursos. Portanto, esse sistema gera a formação de poupança privada na economia. Mas esse acúmulo de ativos financeiros, na forma de lastro dos benefícios, estará sujeito ao risco de mercado e, assim, poderá causar perdas nos valores desses benefícios. No sistema misto combina-se uma cobertura universal, em sistema de repartição, com um sistema de capitalização privado e individual.

Combinado a esses sistemas há dois tipos de planos de benefícios — os planos de benefícios determinam como será calculado o valor do beneficio recebido pelo trabalhador. O primeiro deles, Plano de Benefício Definido (PBD), tem o valor do benefício calculado através de uma média da remuneração (algumas vezes é média das remunerações, mas o mais comum é a remuneração final no momento da aposentadoria) 
para cada ano de serviço. No PBD, o valor do benefício é pré-determinado e a contribuição segue o mecanismo de financiamento dos atuais beneficiários. A maioria dos países industrializados e em desenvolvimento adota o sistema de repartição com PBD. Há também outras opções, como um regime de capitalização com PBD que é muito comum no setor privado. O segundo tipo, o Plano de Contribuição Definida (PCD), tem o valor das contribuições pré-determinadas e os benefícios refletem a quantidade de recursos acumulados até a aposentadoria. Sistemas de repartição com PCD são raros, mas regimes de capitalização com PCD estão se tornando cada vez mais comuns.

\subsection{O sistema previdenciário Brasileiro}

A previdência social no Brasil é composta, basicamente, por dois sistemas de repartição: o Regime Geral de Previdência (RGPS) do INSS, que atende aos trabalhadores do setor privado, e os Regimes Próprios de Previdência dos Servidores (RPPSs), que atendem aos servidores do setor público. As fontes de recursos que financiam os RGPS provêem das contribuições de empregados e empregadores e das transferências da União. No caso dos empregados há uma diferenciação por faixa de renda e para as empresas há ainda uma sobrealíquota, cujo valor depende do risco do setor de atividade. A parcela mais relevante das transferências vem das contribuições sociais, tais como a CPMF, CSLL e COFINS.

O número mínimo de anos de contribuição, na maior parte dos casos, é de 35 anos para os homens e 30 anos para as mulheres. $\mathrm{O}$ valor do benefício de aposentadoria por tempo de contribuição corresponde à média dos $80 \%$ maiores salários. Este valor é corrigido anualmente de acordo com os índices de inflação, visando à manutenção do seu valor real. Trabalhadores do setor informal, ou seja, não contribuintes, podem se aposentar por idade, tendo direito a um benefício equivalente a um salário mínimo, aos 60 anos de idade se mulher e 65 anos se homem.

Os RPPSs são na verdade um conjunto heterogêneo de sistemas previdenciários dos militares e dos funcionários públicos estatutários dos níveis federal, estadual e municipal. As alíquotas de contribuição são diferenciadas por ocupação e esfera do 
setor público. Até a aprovação da EC 41, o valor do benefício dos atuais servidores públicos correspondia ao último e maior salário recebido, ao qual recebia o nome de integralidade. Além disso, havia a paridade, ou seja, o valor real dos benefícios crescia juntamente com os salários dos trabalhadores ativos - privilégios inacessíveis aos trabalhadores do setor privado. Os futuros servidores públicos não terão direito a nenhuma dessas duas vantagens. Alem disso os servidores ferais que ingressarem após a criação do Fundo Federal e vierem a receber remuneração superior ao piso previdenciário terão seus benefícios pagos em um sistema misto - o RPPS pagará somente até o valor do piso e o complemento será pago pelo Fundo de acordo com os seus recursos acumulados.

Tabela 1: Déficits do RGPS e do RPPS

\begin{tabular}{lcccccccc}
\hline Ano & 2000 & 2001 & 2002 & 2003 & 2004 & 2005 & 2006 & 2007 \\
\hline Déficit RGPS & 8,6 & 11,2 & 15,2 & 24,5 & 32,0 & 37,6 & 42 & 46,3 \\
Receita & 56,1 & 62,9 & 71,6 & 80,7 & 93,7 & 108,4 & 123,5 & 135,9 \\
Benefícios & 64,7 & 74,1 & 86,8 & 105,2 & 125,7 & 146 & 165,5 & 182,2 \\
Déficit RPPS & 22,3 & 25,8 & 28,4 & 30,5 & 31,7 & 31,5 & 36,1 & 33,8 \\
Receita & 3,5 & 4,1 & 5,4 & 5,3 & 7,9 & 11,5 & 11,3 & 18,0 \\
Benefícios & 25,8 & 29,9 & 33,8 & 35,8 & 39,6 & 43 & 47,4 & 51,8 \\
\hline
\end{tabular}

Fonte: Ministério Planejamento. Valores em Bilhões.

A Tabela 1 apresenta as receitas e despesas, tanto no RGPP, quanto do RPPS dos servidores federais para o período 2000-2007 e os déficits correspondentes. Existe um grave desequilíbrio estrutural em todo o sistema. Obviamente não é adequado que regimes de repartição gerem déficits tão elevados. Esta situação, apesar de ter se agravado nos últimos anos, tem raízes bastante antigas e vários componentes. Por exemplo, até 1993 em alguns estados e municípios, as contribuições destinavam-se a custear apenas as pensões. De forma análoga, somente em 1998 é que foi definida, pela EC 20 uma idade mínima para a aposentadoria dos servidores públicos, ainda assim de apenas 53 anos para os homens e 48 para as mulheres. No INSS, em 2002, a idade média de aposentadoria era de apenas 54,2 anos, mas ainda assim superior aos 48,9 anos verificados em 1998. Como resultado do rápido envelhecimento da população brasileira, a relação entre contribuintes e beneficiários decresceu rapidamente, passando de 2,50 em 1990 para 1,28 em 2001 (ZYLBERSTAJN, 2006). A conseqüência desses fatos foi o aparecimento de um déficit elevado e crescente, conforme podemos observar na tabela 
1. A tabela nos mostra que os déficits dos servidores públicos federais apesar de bastante elevados em termos absolutos - esses déficits são ainda mais elevados em termos relativos, pois esse sistema atende um número bem menor de beneficiários que o INSS - tiveram um crescimento bem menor que o déficit do RGPS que cresceu alarmantemente nesse período. 


\section{Metodologia e dados}

Neste capitulo introduziremos as principais características do modelo. Em termos mais gerais descreveremos como ocorre à transição de um sistema de repartição para um sistema misto, onde convivem dois sistemas: repartição e capitalização. Esse será o sistema de previdência que o governo federal irá adotar a partir da criação do Fundo federal. O capítulo está estruturado da seguinte forma: na seção 3.1 apresentamos qual será o modelo adotado. Na subseção 3.1.1 analisamos o fundo de investimentos; subseção 3.1.2 as carteiras de investimento; subseção 3.1.3 a implementação das contas pessoais em um modelo com fundo de investimentos. Finalmente, na seção 3.2 descrevemos os dados utilizados.

\subsection{Modelo}

Para esse trabalho utilizaremos como proxy o modelo de Feldstein e Samwick (2001) que sugere a transição de um sistema de repartição para um sistema misto, onde convivem dois sistemas: repartição e capitalização. Na proposta do modelo o mercado de capitais exerce um papel importante na evolução do Fundo previdenciário, pois através das taxas de rentabilidade obtidas no mercado de capitais americano as contribuições conseguem atingir elevados níveis de rentabilidade para os benefícios futuros. Todavia, de acordo com Matijascic e Kay (2006), quando esse modelo é aplicado na América Latina ele sofre da falta de opções domésticas de "Investment Grade" (ações de empresas consideradas seguras) e, complementar a essa deficiência, há a dominância de títulos do governo nas carteiras dos fundos de pensões. Sabemos que a diversificação é fundamental para diminuir o risco de investimento de uma carteira, entretanto, como constatam Matijascic e Kay (2006), as carteiras dos fundos de pensão na América Latina são, predominantemente, formadas por títulos de emissão dos governos locais, pois há poucas opções de investimentos em títulos privados como observado anteriormente. Portanto, como em qualquer caso onde os investimentos estão demasiadamente concentrados, o risco de investimento é maior do que se estivesse em uma carteira diversificada. Isso pode gerar sérios danos aos retornos dos fundos de pensão. 
De acordo com Hemming (1999), além dos problemas associados à composição da carteira, um risco econômico que tem efeitos distintos nos regimes de repartição e capitalização é o impacto da inflação. Um sistema de previdência está sujeito a sobreviver em uma economia com altas expectativas de inflação. $\mathrm{O}$ fato de financiar benefícios indexados através de contribuições indexadas é uma grande vantagem do regime de repartição. Por outro lado, em um regime de capitalização, o maior problema deve-se à inflação inesperada que pode causar perdas aos fundos. Uma possível solução é a composição de carteiras indexadas. Entretanto, tais carteiras são dominadas por títulos do governo que, historicamente, são caracterizados por baixo rentabilidade real e algumas vezes por rentabilidade negativa.

A partir dessas considerações, o modelo das Contas de Aposentadorias Pessoais (CPA) será implementado num regime misto, no qual, além de receber os benefícios do regime de repartição, cada indivíduo terá uma Conta Pessoal de Aposentadoria (CPA), na qual seus recursos serão depositados e capitalizados. No presente caso, os recursos para formação das poupanças dos servidores federais viriam da transferência de $7,5 \%$ das remunerações dos servidores e 7,5\% do Governo Federal. Os recursos das CPA seriam acumulados no Fundo e investidos em ativos do mercado financeiro.

Dessa forma, a transição do atual regime de repartição para o regime misto será feita gradativamente de forma que o sistema de repartição irá diminuindo sua participação na provisão de benefícios até uma participação mínima.

Com a consolidação do Fundo e a capitalização dos recursos nas CPA, os benefícios seriam combinados de forma que uma parte seria provida pelo regime de repartição através do governo e outra parte pelo regime de capitalização através dos recursos capitalizados da CPA.

Os investimentos nas CPA estão sujeitos a riscos econômicos. O risco mais claro é o risco de mercado associado às possíveis variações de preços nos ativos da carteira das CPA. Outro risco considerável é o risco de crédito, no caso de algum dos ativos não conter lastro por parte do emissor. Além disso, a inflação pode causar perdas no caso da carteira possuir ativos não indexados. Para minimizar esses riscos, a forma mais simples 
é adotar políticas de investimento adequadas - fazendo diversificação dos ativos, por exemplo - visando garantir os benefícios no longo prazo.

\subsubsection{Fundo de Investimento}

Todas as movimentações de recursos do Fundo são denominadas em cotas. Quando os cotistas investem ou solicitam o resgate no fundo, torna-se necessário quantificar o número de cotas que eles estão adquirindo ou resgatando.

$\mathrm{Na}$ formação inicial do fundo, o valor da cota é igual a $\mathrm{R} \$ 1,00$. Em qualquer tempo t, o valor da cota $(\mathrm{Ct})$ é uma fração do patrimônio líquido (PLt) do fundo. Esse valor é calculado diariamente dividindo-se o valor do patrimônio líquido (PLt) pelo número de cotas emitidas (Qt), conforme a equação 1 .

$$
C_{t}=\frac{P L_{t}}{Q_{t}}
$$

A valorização ou desvalorização dos ativos da carteira do fundo, bem como receitas e despesas, a taxa de administração, apropriação de dividendos, lucro ou prejuízo da venda de um ativo, ou seja, toda a movimentação do fundo afeta seu patrimônio líquido. Por conseqüência, afeta o valor da cota. Dessa forma, podemos descrever o patrimônio líquido (PLt) na Equação 2.

$$
P L_{t}=C T_{t}+R_{t}+V R_{t}-V P_{t}
$$

onde:

PLt $=$ Valor do patrimônio líquido;

$\mathrm{CTt}=$ Valor atualizado da carteira de títulos;

$\mathrm{Rt}=$ Disponibilidade de recursos;

$\mathrm{VRt}=$ Valores a receber;

$\mathrm{VPt}=$ Valores a pagar.

A carteira de títulos $(\mathrm{CTt})$ é o conjunto de ativos adquiridos pelo fundo. A disponibilidade de recursos (Rt) é o saldo de recursos que ingressaram e não foram utilizados na aquisição de novos títulos e/ou pagamento de resgates. Em geral, é o saldo 
de caixa. Os valores a receber e a pagar (VRt e VPt) são recursos mobilizados, antecipadamente, de compra ou venda de ativos com liquidação a prazo. Para isso se faz a provisão desses recursos, embora ainda não pagos ou recebidos.

No caso da emissão ou resgate de cotas, a quantidade de cotas emitidas ou resgatadas (Qt) é determinada pela divisão do valor aplicado ou resgatado pelo valor da cota no dia da aplicação, de acordo com a equação 3 .

$$
Q_{t}=\frac{C T B R_{t}}{C_{t}}
$$

onde CTBRt é valor aplicado ou resgatado no fundo e Ct é o valor corrente da cota.

\subsubsection{Carteiras de Investimento}

Para calcular o valor real da cota do fundo de investimento, seguiremos a prática de mercado. No momento da formação do Fundo, faremos o valor da cota do fundo ser igual a R\$ 1,00. Mensalmente, essa cota é reajustada de forma a refletir a evolução de rentabilidade do Fundo. Para isso, a cota do Fundo será calculada mensalmente usando as equações 1 e 2 considerando as despesas e rentabilidade mensal da carteira corrigida pela taxa de inflação corrente. Dependendo da composição da carteira teremos diferentes retornos. A rentabilidade de uma carteira diversificada é apenas o retorno individual dos ativos ponderados pela sua participação na carteira do fundo, logo o valor da cota será calculada de acordo com a equação 4 .

$$
C_{t}=\sum_{i=1}^{n} w_{i} X_{i}
$$

onde, Ct é o valor da quota no mês t; wi é a participação do ativo i no total da carteira, condicionado a $\sum_{i=1}^{n} w_{i}=1$ e Xi é o fator de rentabilidade acumulada do ativo i até o mês t.

Os recursos acumulados no Fundo são expressos em quantidade de cotas. Mensalmente, as contribuições aplicadas no Fundo se transformam em cotas. Logo, para encontrar a 
quantidade de recursos acumulados no Fundo, devemos multiplicar o número de cotas pelo valor da cota atual. Portanto, o valor dos recursos acumulados no Fundo pode ser expresso usando a equação 5.

$$
P L_{n}=C_{n} *\left(\sum_{t=1}^{n} \frac{C T R B_{t}}{C_{t}}\right)
$$

onde, PLn é o total de recursos acumulados no fundo; Cn é o valor da quota no fim do período $\mathrm{n}$; $\mathrm{Ct}$ é o valor da cota no momento t; CTBRt é o valor atualizado da contribuição depositado no Fundo no mês t. Logo, o termo da equação entre parênteses refere-se à quantidade de cotas adquiridas em períodos anteriores.

\subsubsection{Implementação das Contas Pessoais de Aposentadoria}

A proposta para a criação do Fundo Previdenciário Federal estabelece que o fundo previdenciário seja de contribuição definida, isto é, os indivíduos recebem suas aposentadorias em função da quantidade de recursos acumulados. Dessa forma, para obter o saldo acumulado individual, precisamos encontrar a quantidade total de contribuições feitas pelos indivíduos até o momento de sua aposentadoria e fazermos a capitalização desses recursos ao longo do tempo. A equação 6 fornece o valor do saldo acumulado individual:

$$
P L_{n}^{i}=\sum_{t=1}^{n} T x_{t} W_{t}^{i}\left(1+r_{t}\right)^{n-t}
$$

onde, $P L_{n}^{i}$ é o saldo acumulado das contribuições do individuo i capitalizadas até o mês n; $T x_{t}$ é a taxa de contribuição no mês t; $W_{t}^{i}$ é o salário do indivíduo i no mês t; $T x W_{t}^{i}$ é a contribuição do indivíduo i para o Fundo no mês t; $r_{t}$ é a rentabilidade real da carteira no mês t. Repare que a equação 6 nos diz que o saldo acumulado pelo indivíduo é o somatório das contribuições capitalizadas, ou seja, o saldo individual pode ser expresso pela equação 7. 


$$
P L_{n}^{i}=C_{n} \sum_{t=1}^{n} \frac{T x_{t} W_{t}}{C_{t}}
$$

onde, Cn é o valor da quota no mês n e Ct é o valor da cota no momento t. Isto é, temos um resultado intuitivo, que nos diz que o somatório de todos os saldos das contas individuais dos aposentados nos fornece o valor de recursos acumulados no Fundo. Logo, ao agregar a equação 6 de todos os indivíduos teremos a equação 5 .

O benefício pago aos aposentados é função do saldo acumulado ao longo da vida de trabalho, ou seja, as aposentadorias são pagamentos mensais, em parcelas iguais, que esgotarão o montante de recursos acumulados dentro de um período específico projetado no futuro. Este processo envolve a determinação dos pagamentos futuros (dentro do período especificado), cujo valor presente, calculado à taxa de rentabilidade real, iguala-se ao saldo acumulado até o momento da aposentadoria. Logo, para obter o valor das mensalidades precisamos, primeiro, calcular o Fator de Valor Atual de uma Anuidade à taxa $\mathrm{k}$ em $\mathrm{n}$ períodos (FVAAk,n), o que é feito na equação 8.

$$
F_{V A A_{k, n}}=\sum_{t=1}^{n} \frac{1}{(1+k)^{t}}
$$

Onde, FVAA é o fator de valor atual de uma anuidade de \$1 descontada a taxa k para $\mathrm{n}$ períodos. A partir do fator dado na equação 8 podemos encontrar o valor de cada parcela que o aposentado irá receber através da equação 9.

$$
A=\frac{P L_{n}^{i}}{F V A A_{k, n}}
$$

Onde, $P L_{n}^{i}$ é o saldo acumulado do indivíduo i no mês n, definido antes, FVAA é o fator de valor atual de uma anuidade e A o valor da aposentadoria a ser paga a partir do Fundo.

O comportamento da CPA pode ser descrito conforme o gráfico 1. Para isso basta analisar a evolução do saldo da conta. A evolução do saldo pode ser analisada em dois 
períodos: o período de contribuição e o período de recebimento de benefícios. Durante o período de contribuição são feitas contribuições para CPA que são capitalizadas ao longo do tempo até o momento da aposentadoria do servidor. A partir desse momento o servidor começa a receber a mensalidade da CPA. Porém, os recursos acumulados continuam a ser capitalizados. Os gráficos podem ser generalizadas, pois o comportamento para todos os servidores será muito semelhante, diferindo apenas quanto aos valores acumulados, períodos de aposentadoria e morte dos servidores.

\section{Gráfico 1 - Evolução do saldo da Conta Pessoal de Aposentadoria}

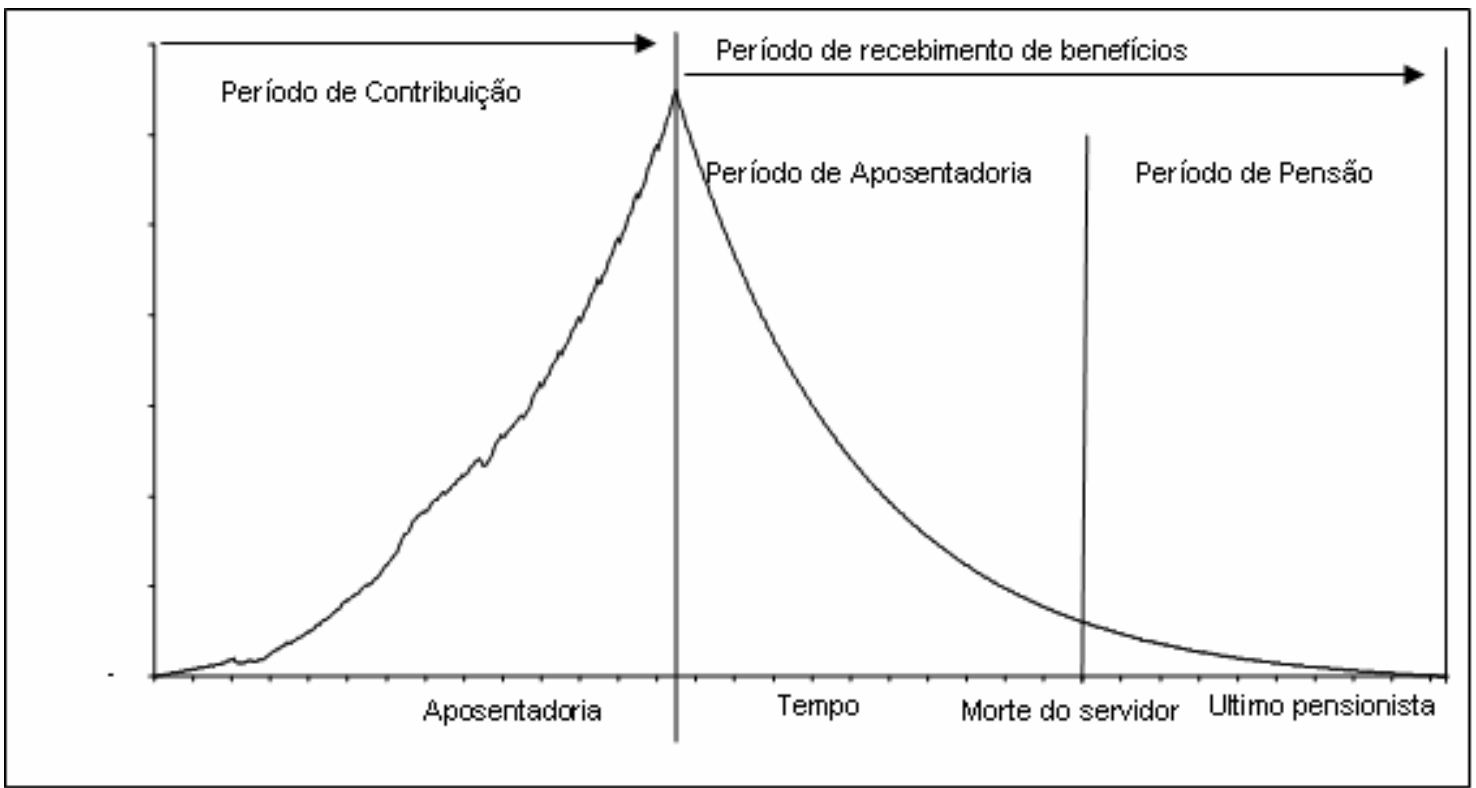

Fonte: Yamasaki, Fabio, O modelo das contas pessoais de aposentadoria na Universidade de São Paulo. São Paulo: Universidade de São Paulo, 2006.

\subsection{Dados Utilizados}

As principais variáveis para esse trabalho, tais como: a) idade média de ingresso no serviço público do servidor; b) remuneração do servidor, em setembro de 2007; e c) cargos dos servidores foi retirado do MPOG (Ministério Planejamento, Orçamento e Gestão), através de seu "sitio" na internet. Já as tábuas de mortalidade para o ano de 2005, último ano disponível, foi fornecido pelo IBGE (Instituto Brasileiro de Geografia e Estatística) através de seu "sitio" na internet. Finalmente, para calcularmos o aumento dos rendimentos anuais dos servidores e o desvio padrão da diferença de idades entre os servidores utilizamos os microdados da PNAD (Pesquisa Nacional por Amostra de 
Domicílio) do ano de 2005. As leis e muitos artigos sobre previdência social utilizados nesse trabalho foram retirados do "sitio" do MPS (Ministério Previdência Social). 


\section{Obrigações Previdenciárias}

Nesse capítulo descreveremos as principais obrigações previdenciárias de um sistema previdenciário. Na seção 4.1 faremos uma apresentação geral dos principais desdobramentos previdenciários de um servidor. Na seção 4.2. mostramos as alternativas e os custos para os servidores federais a partir da criação do fundo federal. Por fim, na seção 4.3 descrevemos as principais variáveis que serão utilizadas nos modelos matemáticos que descreverão as principais obrigações previdenciárias: seção 4.4, aposentadoria programada; seção 4.5, aposentadoria por invalidez; e seção 4.6, pensão por morte.

\subsection{Principais Desdobramentos Previdenciários}

As obrigações previdenciárias não apresentam valor conhecido e nem data certa para pagamento, ou seja, elas possuem incertezas ligadas ao momento de ocorrência e ao valor do benefício. A palavra incerteza, nesse trabalho, tem uma acepção equivalente à palavra risco, já que são conhecidas algumas informações sobre os eventos futuros que nos permitem calcular suas esperanças matemáticas e valores presentes atuariais. As incertezas relativas ao momento de ocorrência decorrem de riscos biométricos, ou seja, a data da liquidação financeira dessas obrigações é indeterminada, pois depende de eventos probabilísticos de morte ou sobrevivência dos segurados e seus beneficiários, da sua entrada em invalidez e da sua retirada do emprego, cujas distribuições de probabilidades devem ser conhecidas.

Já a incerteza em relação aos valores decorre de riscos financeiros. Os valores destas obrigações também são de natureza probabilística, haja vista a aleatoriedade e amplitude que eles podem assumir, pois dependem das características previdenciárias e laborais de cada indivíduo, como, por exemplo, o crescimento salarial que cada pessoa terá ao longo da carreira. A incerteza desses parâmetros faz com que seja necessário o uso de hipóteses, suposições sobre o comportamento futuro das variáveis que interferem no equilíbrio atuarial do regime de previdência. Os eventos geradores dos benefícios para os servidores e dependentes são os de aposentadoria e pensão. A tabela 2 mostra os principais desdobramentos previdenciários para o Regime Próprio de Previdência dos 
Servidores Públicos da União (RPPS).

Tabela 2: Regime Próprio de Previdência dos servidores Públicos da União

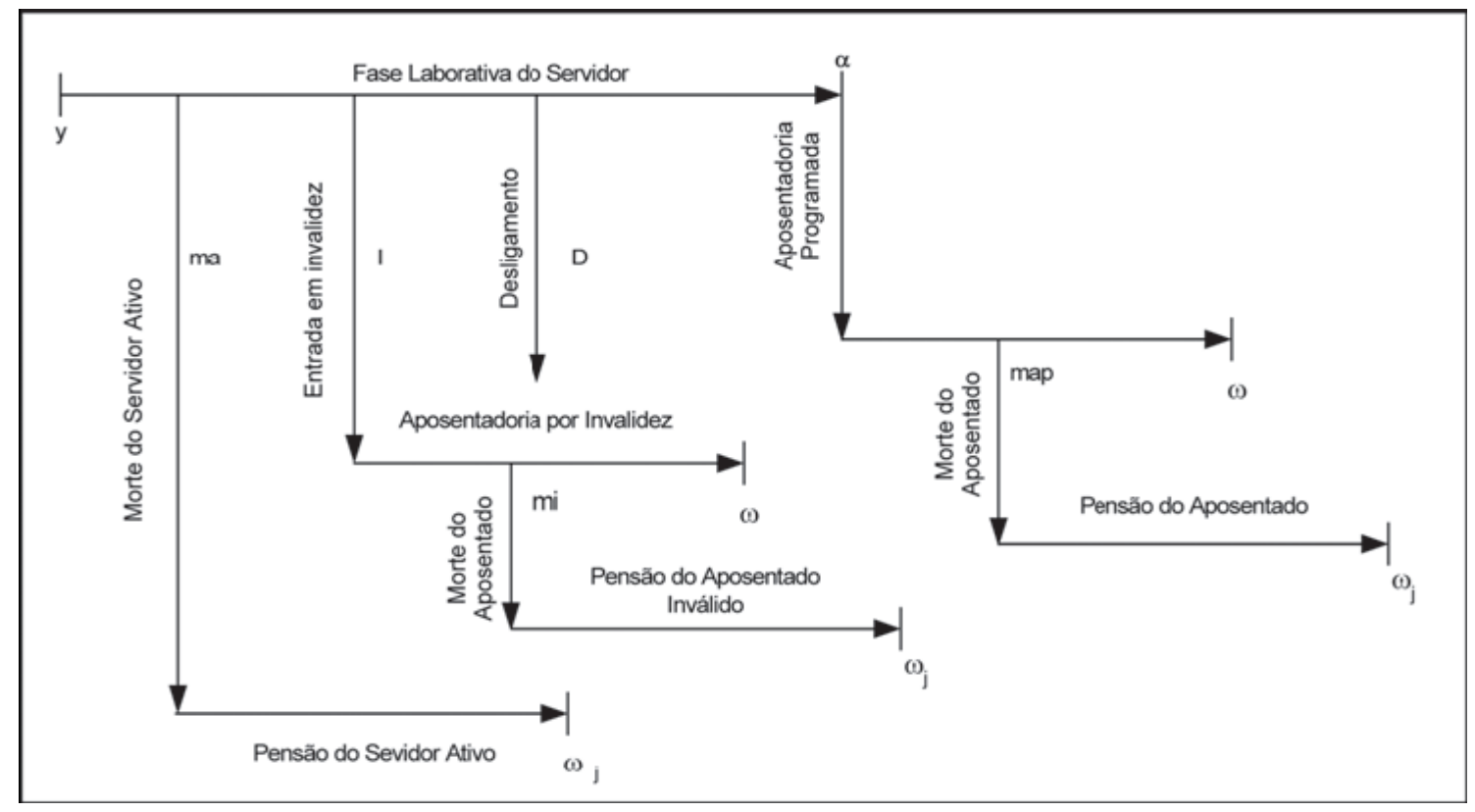

Fonte: FONTOURA, Francisco Robson da Silva. Avaliação da Solvência Econômico-Financeira de Entidades Municipais Gestoras de Regimes Próprios de Previdência Social.

Nota: $\mathrm{y}$ - idade de entrada no sistema; $\alpha$-idade da aposentadoria programada; ma - morte do servidor ativo; map - morte do aposentado; mi - morte de inválido; $\omega$ - idade limite da tábua de mortalidade do servidor; $\omega \mathrm{j}$ - idade limite da tábua de mortalidade para o pensionista; D - desligamento; I- entrada em invalidez.

Durante a fase laborativa do servidor há a probabilidade de ocorrência de quatro eventos estocásticos, como pode ser observado na tabela 2: i) a morte do servidor ativo (ma); ii) a sua entrada em invalidez (I); iii) o seu desligamento (D), ou; iv) a sua sobrevivência a estes decrementos durante a extensão da fase laborativa, atingindo, assim, a idade de entrada em aposentadoria programada.

O primeiro evento, ma, morte do servidor durante a fase laborativa, gera a obrigação de iniciar o pagamento do benefício de pensão aos dependentes legais do de cujus. $\mathrm{O}$ segundo evento, $\boldsymbol{I}$, entrada em invalidez, ocasiona o pagamento do benefício de aposentadoria por invalidez ao próprio servidor inválido durante a sua sobrevida. Caso o aposentado inválido venha a falecer, mi (morte de inválido), ele deixará ao seu grupo 
familiar, e enquanto este existir, o direito ao recebimento da pensão. É importante definir a existência do grupo familiar no sentido mais amplo do que apenas imaginar o seu desaparecimento pela morte dos seus integrantes. No contexto dessa análise, o grupo familiar sobrevivente, para todos os eventos vinculados à pensão, deixa de existir quando os seus componentes não atenderem às condições de manutenção da elegibilidade aos benefícios de pensão, sejam pela morte ou por outras condições previstas em lei. O terceiro evento, $\boldsymbol{D}$, desligamento, afasta o servidor do Fundo Previdenciário e não gera, a princípio, a obrigação de pagamento de nenhum benefício, pois este perde o vínculo com a União.

Caso o servidor percorra toda a extensão da fase laborativa, vivo e válido, incorrerá no quarto evento, tornando-se elegível ao benefício de aposentadoria programada. Receberá, a partir de então, sua renda de inatividade até o seu falecimento, de acordo com as regras do plano. Durante o período de usufruto do benefício de aposentadoria programada, a morte do aposentado, map, gera o pagamento do benefício de pensão aos respectivos dependentes enquanto as exigências legais do status de dependência forem satisfeitas.

A partir dos desdobramentos previdenciários, podem-se compreender as causas de entrada em aposentadoria, pensão e de eliminação de ativos, aposentados e pensionistas, que é fundamental para se projetar o fluxo de benefícios a serem pagos.

O grupo dos ativos é peculiar, pois além da morte como causas de eliminação há também a entrada em invalidez, a entrada nas demais aposentadorias e o desligamento. Por sua vez, esses são fatores de entrada nos demais grupos, com exceção do evento de desligamento. Portanto, as causas de eliminação dos ativos são as responsáveis pelas entradas nos demais grupos.

\subsection{Alternativas para o servidor que tem remuneração acima do piso previdenciário}

A partir dos desdobramentos previdenciários apresentados, e dos meios legais descritos no anexo, o servidor que ingressou no serviço público antes da criação do fundo previdenciário e possui remuneração acima do piso previdenciário terá duas alternativas: a) não participar do fundo previdenciário e nesse caso continuar 
contribuindo com uma alíquota de $11 \%$ sobre a sua remuneração e ter seu beneficio pago integralmente pelo RPPS; b) participar do Fundo e para isso contribuir para o Fundo com uma alíquota de até 7,5\% sobre o valor de sua remuneração que exceder o valor do piso previdenciário e contribuir para o RPPS com uma alíquota de $11 \%$ sobre o valor do piso previdenciário. Nesse caso terá seu beneficio pago de forma mista. $\mathrm{O}$ valor do piso previdenciário será pago pelo RPPS. O Fundo pagará um beneficio equivalente ao valor acumulado pelo servidor e proporcional a sua expectativa de vida.

Já o servidor que entrar após a criação do Fundo deverá participar do Fundo obrigatoriamente. Para o servidor que entra depois da criação do fundo valerá a ultima regra descrita no parágrafo anterior, item " $\mathrm{b}$ ".

Podemos concluir, a partir do exposto acima, que os servidores federais que ingressaram no serviço público antes da criação do fundo poderão escolher se querem ingressar no Fundo Previdenciário ou não - disporão de 180 dias a partir da criação do fundo para fazer a opção. A partir dessa escolha eles poderão ter aposentadorias/pensões maiores ou menores a depender da forma como funcionará o Fundo e de como comportará algumas variáveis, determinantes para o desempenho do Fundo, tais como, juros, salários, administração do fundo, expectativa de vida, etc.

Portanto, faz-se necessário nesse trabalho calcular o valor dos benefícios dos servidores que não participarão do fundo e daqueles que irão participar a fim de compará-los. Vale lembrar que serão calculados os valores dos benefícios apenas dos servidores com remunerações superiores ao teto do piso previdenciário, pois servidores com remunerações abaixo do piso previdenciário não ingressarão no fundo e terão seus benefícios pagos integralmente pelo RPPS.

\subsection{Formulação Matemática dos benefícios pagos pelo RPPS}

Conhecendo-se o desdobramento dos benefícios e as hipóteses utilizadas, pode-se apresentar o modelo geral usado para o cálculo dos benefícios, aposentadorias e pensões, em cada momento do tempo. O cálculo será realizado para cada pessoa ligada ao plano de benefícios. Com a informação do período contributivo, analisa-se a probabilidade de ocorrência dos eventos de morte, invalidez ou desligamento do 
servidor dentro deste período.

Será apresentada, a seguir, a notação empregada para mensurar os encargos previdenciários do servidor em cada momento do tempo, considerando os desdobramentos previdenciários já apresentados.

Para melhor compreensão da formulação matemática, será apresentada, previamente, a notação utilizada nas equações:

VPA - valor presente atuarial;

0 - data-base da avaliação;

$\mathrm{t}$ - momento, em anos, da projeção;

$\mathrm{k}$ - momento da aposentadoria por invalidez;

a - momento da aposentadoria programada;

$\omega$ - idade máxima da tábua de mortalidade;

$\alpha$-idade da aposentadoria programada

$\mathrm{y}$ - idade de entrada no sistema;

$\mathrm{x}$ - idade na data da avaliação;

h - aumento geral dos salários do setor público que, por hipótese, vamos supor igual ao aumento da produtividade da economia;

g - aumento particular de salário, decorrente da progressão na carreira (tempo de serviço);

$\mathrm{p}$ - probabilidade de morte;

d - probabilidade de permanência em atividade;

ma - morte de ativo;

map - morte do aposentado

mi - morte de inválido;

$\mathrm{mp}$ - morte de pensionista;

I - entrada em invalidez;

D - desligamento do servidor;

i - servidor (segurado);

$\mathrm{j}$ - grupo familiar do servidor.

\subsection{Aposentadoria Programada}


O valor da aposentadoria programada refere-se às aposentadorias por tempo de contribuição, idade e compulsória e pode ser representado graficamente pela tabela 3 e matematicamente está descrita pela equação 10:

Tabela 3: Fluxo de Aposentadoria Programada a Conceder

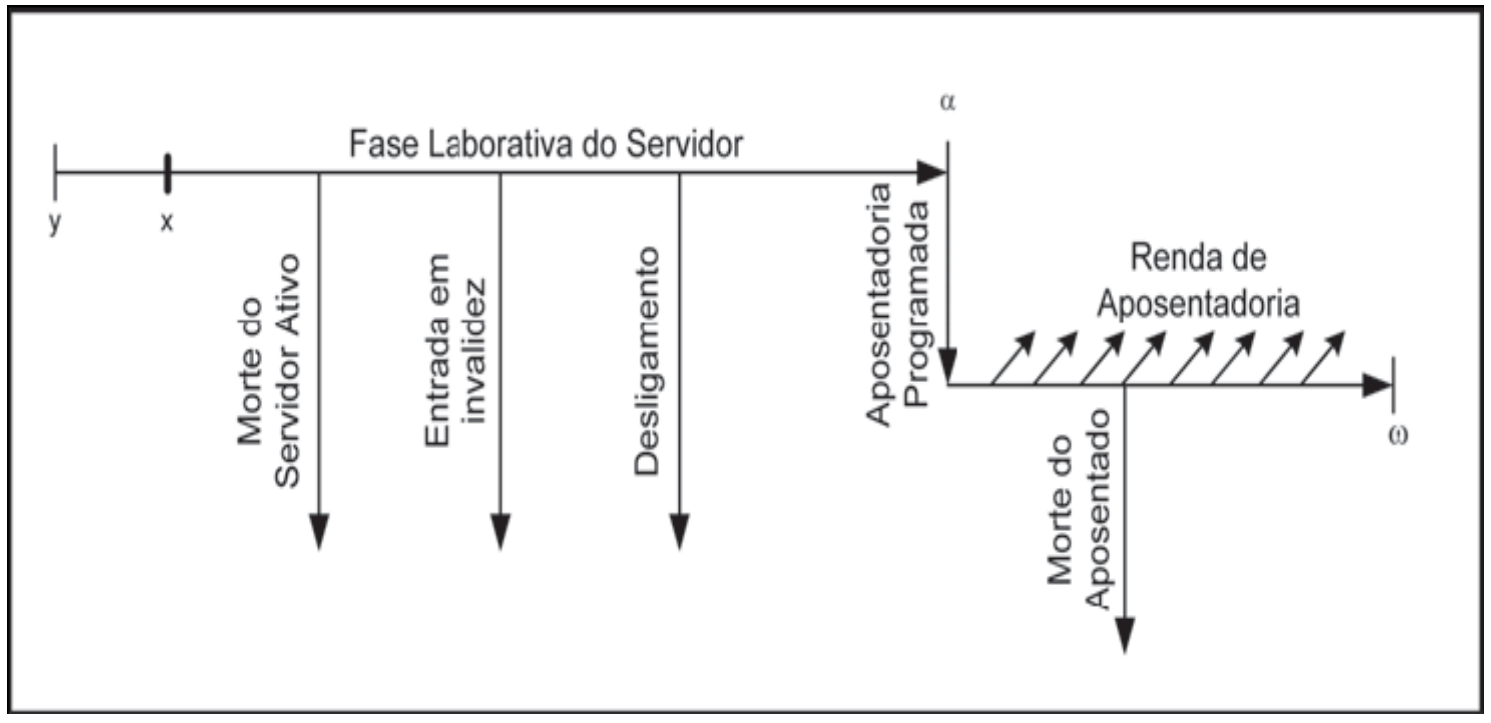

Fonte: FONTOURA, Francisco Robson da Silva. Avaliação da Solvência Econômico-Financeira de Entidades Municipais Gestoras de Regimes Próprios de Previdência Social.

Nota: $\mathrm{y}$ - idade de entrada no sistema; $\mathrm{x}$ - idade na data da avaliação; $\alpha$ - idade da aposentadoria programada; $\omega$-idade limite da tábua de mortalidade do servidor.

$$
\begin{aligned}
& \operatorname{VEAP}_{i, t}=\left(\operatorname{VAP}_{i, t}\right) *\left({ }_{x} d_{x+a}\right) *\left({ }_{x+a} p_{x+t}\right) \\
& \operatorname{VAP}_{i, t}=\left(V_{i, 0}\right) *\left(e^{(g+h) * t}\right)
\end{aligned}
$$

ingressou até 2003.

$V A P_{i, t}=\left(\sum_{l=0,2^{*} a}^{a}\left(\left(V S_{i, 0}\right) *\left(e^{(g+h)^{*} t}\right) / 0,8 * a\right)\right.$

ingressou depois de 2003.

Onde:

$V E A P_{i, t}$ - Valor Esperado da Aposentadoria do servidor i, no momento t;

$V A P_{i, a}-$ Valor da aposentadoria do beneficiário i, no momento a;

$V S_{i, 0}-$ Valor do salário do servidor i, na data-base 0 ; 
${ }_{a} d_{x}$ - probabilidade de permanência em atividade do servidor $\mathrm{i}$, entre as idades $\mathrm{x}$ e $\mathrm{x}+\mathrm{a}$ ${ }_{t-a} p_{x+a}$ - valor da aposentadoria do servidor $\mathrm{i}$, no momento $\mathrm{t}$ probabilidade de sobrevivência do servidor $\mathrm{i}$, entre as idades $\mathrm{x}+\mathrm{a}$ e $\mathrm{x}+t$;

h - aumento geral dos salários decorrente do aumento da produtividade da economia;

g - aumento particular de salário, decorrente da progressão na carreira (tempo de serviço);

$\mathrm{t}$ - momento da projeção, em anos;

a - momento da aposentadoria;

$\mathrm{x}$ - idade do servidor na data da avaliação;

0 - data-base da avaliação.

A equação 10 apresenta um componente financeiro e outro biométrico e representa o valor esperado de pagamento futuro de benefício de aposentadoria para um atual servidor ativo. O componente financeiro é representado pela equação 10 e traz o valor do benefício da aposentadoria que o servidor terá caso esteja vivo, válido e não se desligue do sistema até o momento t. O componente financeiro será representado pela equação 10.1 se o servidor entrou até 2003 no serviço publico federal. Esse valor será equivalente a remuneração que o servidor tem na data-base da avaliação atualizada pela taxa de crescimento salarial até o momento da projeção. Caso contrário, ou seja, se o servidor entrou depois de 2003 o componente financeiro será representado pela equação 10.2. Esse valor será equivalente a média aritmética simples das $80 \%$ maiores remunerações, calculado a partir de sua remuneração na data base adicionada de sua taxa de crescimento salarial até o momento da projeção.

O componente biométrico representa eventos probabilísticos que podem ocorrer em dois períodos. O primeiro período analisado é o período contributivo do servidor entre as idades " $\mathrm{x}$ " $\mathrm{e}$ " $\mathrm{x}+\mathrm{a}$ ", onde se avalia a probabilidade do servidor permanecer em atividade $\left({ }_{x} d_{x+a}\right)$, ou seja, é o componente que fornece a probabilidade de ele não morrer, não se invalidar, tampouco se desligar do serviço público no período. Caso o servidor ultrapasse esse período, é necessário que se avalie a probabilidade de ele continuar vivo e recebendo o benefício após sua aposentadoria $\left({ }_{x+a} p_{x+t}\right)$.

\subsection{Aposentadoria por Invalidez}


A aposentadoria por invalidez será devida ao servidor que se encontra em atividade, mas poderá se invalidar dentro do período contributivo. Ela pode ser descrita pela tabela abaixo e matematicamente através da equação 11 :

Tabela 4: Fluxo de Aposentadoria Por Invalidez

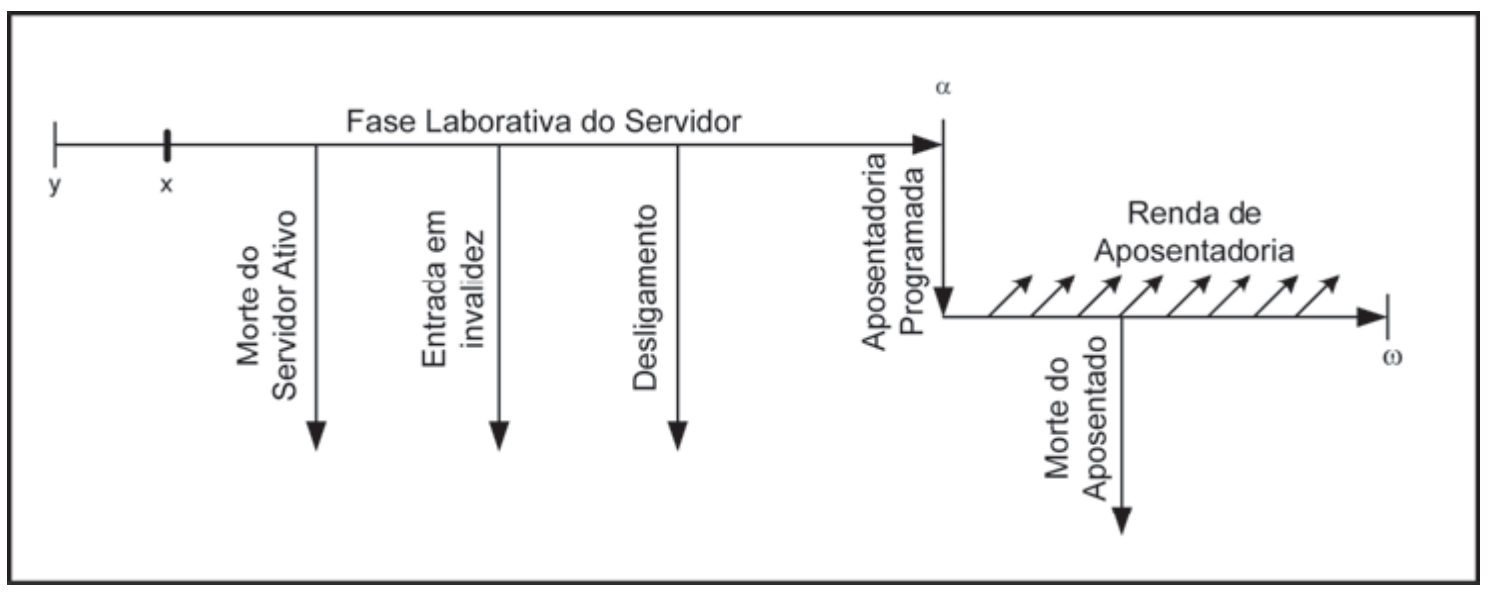

Fonte: FONTOURA, Francisco Robson da Silva. Avaliação da Solvência Econômico-Financeira de Entidades Municipais Gestoras de Regimes Próprios de Previdência Social.

Nota: $\mathrm{y}$ - idade de entrada no sistema; $\mathrm{x}$ - idade na data da avaliação; $\alpha$ - idade da aposentadoria programada; $\omega$ - idade limite da tábua de mortalidade do servidor.

$$
V E A I_{i, t}=\left({ }_{x} d_{x+k}\right) *\left(q_{x+k}^{i n v}\right) *\left[\left(\mathrm{VS}_{\mathrm{i}, 0}\right) *\left(e^{(g+h)^{*} t}\right) *\left({ }_{x+k} p_{x+t}\right)\right], \text { se } k \leq a-1
$$

$\mathrm{VS}_{\mathrm{i}, 0}-$ Valor do salário do servidor i, na data-base 0 ;

h - aumento geral dos salários decorrente do aumento da produtividade da economia;

g - aumento particular de salário, decorrente da progressão na carreira (tempo de serviço);

$\mathrm{t}$ - momento da projeção, em anos;

$\mathrm{k}$ - momento da aposentadoria por invalidez;

a - momento da aposentadoria;

$\mathrm{x}$ - idade do servidor na data da avaliação;

0 - data-base da avaliação. 
Na equação 11, as dimensões de tempo a serem analisadas estão ligadas às incertezas biométricas. A primeira dimensão de tempo está ligada à incerteza biométrica de entrada em invalidez do servidor. Dado a entrada em invalidez do servidor, a segunda dimensão de tempo deve ser analisada. Ela está ligada à incerteza biométrica do servidor inválido estar vivo. $\mathrm{O}$ valor de " $\mathrm{k}$ " na equação 11 inicia-se em 0 porque o servidor ativo pode vir a se invalidar no primeiro ano. Esse valor de "k" vai até "a-1" porque esta é a data máxima de concessão do benefício, depois o servidor estará aposentado e não pode se enquadrar na condição de segurado ativo que virá a se invalidar. A equação 11 apresenta um componente financeiro e outro biométrico e representa o valor esperado de pagamento futuro de benefício de aposentadoria por invalidez de um atual servidor ativo em um momento "t". O componente financeiro é representado pela equação $\left(\mathrm{VS}_{\mathrm{i}, 0}\right) *\left(e^{(g+h)^{*} t}\right)$ e traz o valor do salário que o servidor terá caso se invalide no momento "k" e esteja vivo e recebendo o benefício de invalidez até o momento “t”. Esse valor será equivalente à remuneração que o servidor tem no momento da data-base atualizada pela taxa de crescimento da remuneração de seu cargo, se for extinto de um cargo assemelhado, até o momento da projeção.

O componente biométrico representa eventos probabilísticos que podem ocorrer em dois períodos. O primeiro período analisado é o período contributivo do servidor entre as idades " $\mathrm{x}$ " $\mathrm{e}$ " $\mathrm{x}+\mathrm{k}$ ", onde se avalia a probabilidade do servidor permanecer em atividade $\left({ }_{x} d_{x+k}\right)$, ou seja, é o componente que fornece a probabilidade de ele não morrer, não se invalidar, tampouco se desligar do serviço público no período. Nesse período é analisada também a probabilidade do servidor se invalidar $\left(q_{x+k}^{\text {inv }}\right)$ em uma idade " $x+k$ ". Caso o servidor se invalide em " $x+k$ ", é necessário que se avalie $o$ segundo período, quando se analisará a probabilidade de ele continuar vivo e recebendo o benefício após sua aposentadoria por invalidez $\left({ }_{x+k} p_{x+t}\right)$.

\subsection{Pensões por Morte}

Os benefícios de pensão a conceder podem ser decorrentes da morte do:

4.6.1. servidor ativo que venha a falecer em atividade; 
4.6.2. servidor ativo que alcance a aposentadoria programada e faleça durante a fruição do benefício;

4.6.3. servidor ativo que se invalide e morra durante o recebimento da aposentadoria por invalidez;

4.6.4. servidor aposentado (programada ou por invalidez) que venha a falecer.

Assim, é necessário que se analise cada situação separadamente.

O valor da pensão, segundo a Emenda Constitucional N. ${ }^{\circ} 40 / 03$, será igual aos proventos do servidor falecido, ou aos proventos a que teria direito o servidor em atividade na data do falecimento, até o limite do piso previdenciário - R \$2.400,00 em 2003 e atualizado posteriormente pela inflação acumulada- acrescido de $70 \%$ da parcela excedente a esse limite ${ }^{2}$.

\subsubsection{Pensão do Servidor Ativo}

Essa pensão será devida aos dependentes do servidor que hoje é ativo e que venha a falecer em atividade. Ela pode ser descrita pela tabela 5 e representada pela equação 12:

\section{Tabela 5: Fluxo de Pensão do Servidor Ativo}

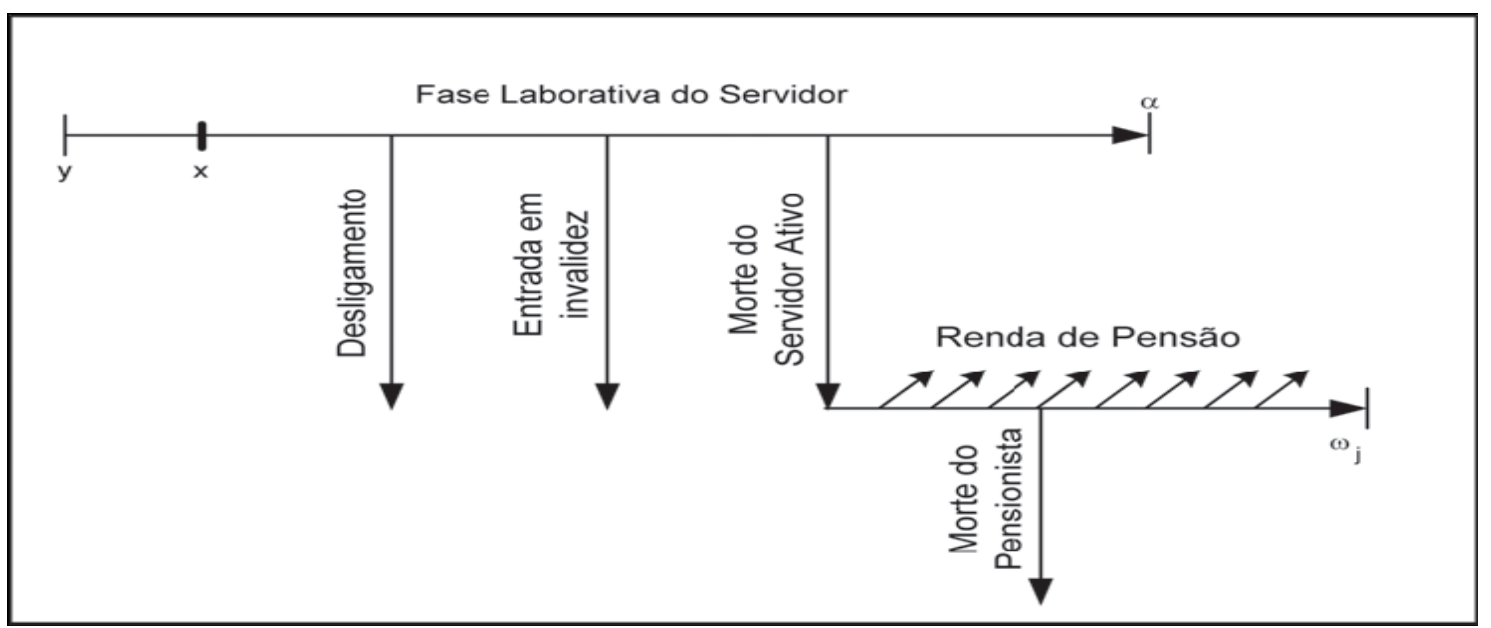

Fonte: FONTOURA, Francisco Robson da Silva. Avaliação da Solvência Econômico-Financeira de Entidades Municipais Gestoras de Regimes Próprios de Previdência Social.

Nota: y - idade de entrada no sistema; $\mathrm{x}$ - idade na data da avaliação; $\alpha$ - idade da aposentadoria programada wj; - idade limite da tábua de mortalidade para o pensionista.

\footnotetext{
${ }^{2}$ A regra legal das pensões estão descritas no anexo 2.
} 
$V P S A_{i, t}=\left({ }_{n} d_{x}\right) *\left(q_{x+n}^{i n v}\right) * V S_{i, t} *\left({ }_{t} p_{0}\right),(1.5)$, se $\mathrm{n} \leq \mathrm{a}-1$

$V S_{i, t}=\left\{\left[\left(\mathrm{VS}_{\mathrm{i}, 0}\right) *\left(\left(e^{(g+h)^{*} t}\right)-P P_{0}\right) *(0,7)\right]+P P_{0}\right\}$

Onde:

$\mathrm{VS}_{\mathrm{i}, 0}-$ valor do salário do servidor i, na data-base 0 ;

$\mathrm{g}$ - taxa de crescimento por produtividade;

h - aumento geral dos salários decorrente do aumento da produtividade da economia;

g - aumento particular de salário, decorrente da progressão na carreira (tempo de serviço);

$\mathrm{t}$ - momento da projeção, em anos;

$\mathrm{n}$ - momento da morte do segurado;

a - momento da aposentadoria;

$\mathrm{x}$ - idade do servidor na data da avaliação;

0 - data-base da avaliação;

$P P_{0}$ - piso previdenciário na data base.

$\mathrm{Na}$ equação 12 as dimensões de tempo a serem analisadas estão ligadas ás incertezas biométricas. A primeira dimensão de tempo está ligada à incerteza biométrica de falecimento do servidor. Dado o falecimento do servidor, a segunda dimensão de tempo deve ser analisada. Ela está ligada à incerteza biométrica do grupo familiar estar vivo. $\mathrm{O}$ valor de " $n$ " inicia-se em 0 porque o servidor ativo pode vir a falecer no primeiro ano. $\mathrm{O}$ valor de $n$ esta limitado em "a-1" porque esta é a data máxima de concessão do benefício, depois o servidor estará aposentado e não pode se enquadrar na condição de segurado ativo que virá a falecer.

A equação 12 apresenta um componente financeiro e outro biométrico e representa o valor esperado de pagamento futuro de benefício de pensão pela morte de um atual servidor ativo. O componente financeiro é representado pela equação 12.1 , pois neste caso o valor da pensão incidirá sobre o valor da remuneração de um servidor ativo. A equação traz o valor do benefício que o grupo familiar “j” terá, caso o servidor morra no momento $\mathrm{n}$ e o grupo familiar esteja vivo e recebendo a pensão até o momento t. Esse 
valor será equivalente a soma de duas parcelas, quais sejam: i) $70 \%$ da diferença entre a remuneração do servidor no momento da data-base e o valor do piso previdenciário, a remuneração será atualizada pela taxa de crescimento salarial $(\mathrm{g}+\mathrm{h})$; e ii) o valor do piso previdenciário.

O componente biométrico representa eventos probabilísticos que podem ocorrer em dois períodos. O primeiro período analisado é o período contributivo do servidor entre as idades " $\mathrm{x}$ " $\mathrm{e}$ " $\mathrm{x}+\mathrm{n}$ ", onde se avalia a probabilidade do servidor permanecer em atividade $\left({ }_{x} d_{x+n}\right)$, ou seja, é o componente que fornece a probabilidade de ele não morrer, não se invalidar, tampouco se desligar do serviço público no período. Nesse período é analisada também a probabilidade do servidor morrer $\left(q_{x+n}\right)$ em uma idade “ $\mathrm{x}+\mathrm{n}$ ”. Caso o servidor faleça em " $\mathrm{x}+\mathrm{n}$ ”, é necessário que se avalie a probabilidade do grupo familiar "j" continuar vivo e recebendo o benefício após sua morte, até o momento de projeção " $\mathrm{t}$ ” $\left({ }_{0} p_{t}\right)$. Se isso não acontecer e o servidor não falecer no período entre as idades " $\mathrm{x}$ " $\mathrm{e}$ " $\mathrm{x}+\mathrm{a}$ ", o servidor terá sua aposentadoria programada.

\subsubsection{Pensão do Servidor Ativo que Alcance a Aposentadoria Programada}

Tabela 6: Fluxo de Pensão do Servidor Ativo que Alcance Aposentadoria Programada

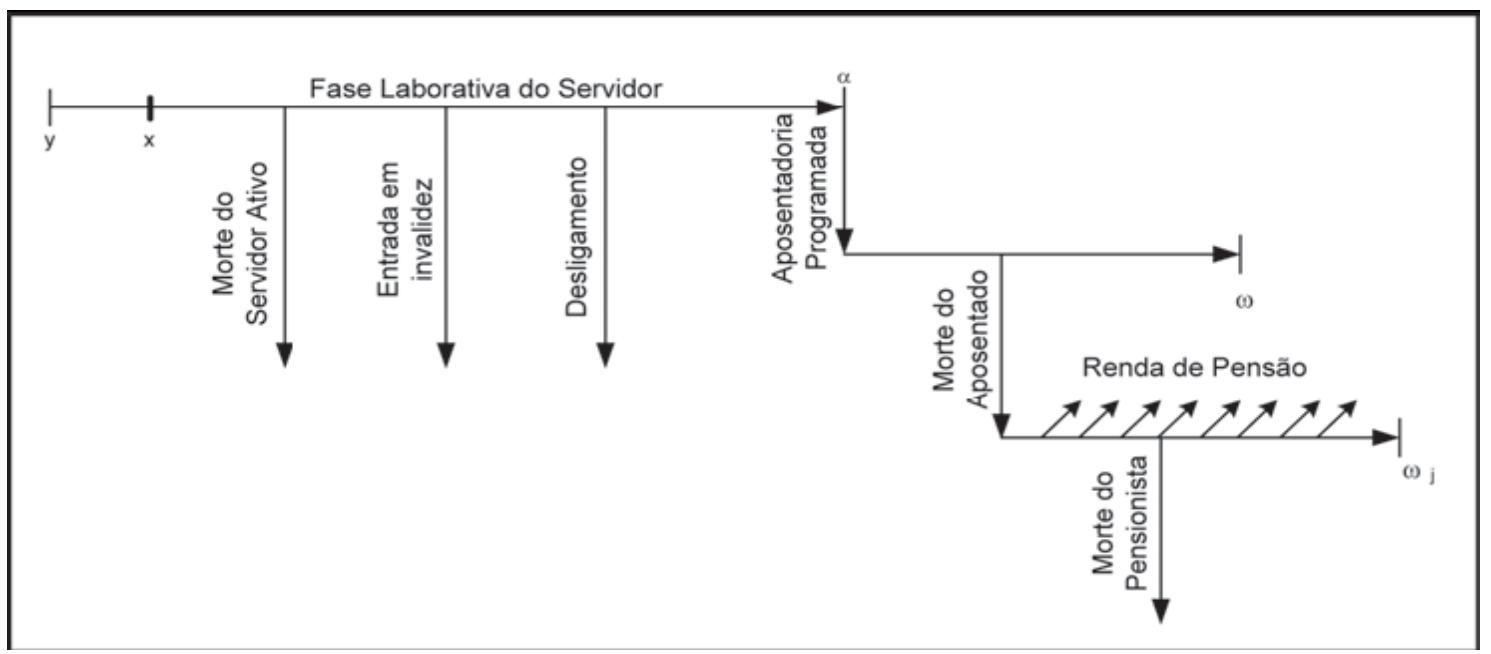

Fonte: FONTOURA, Francisco Robson da Silva. Avaliação da Solvência Econômico-Financeira de Entidades Municipais Gestoras de Regimes Próprios de Previdência Social.

Nota: $\mathrm{y}$ - idade de entrada no sistema; $\mathrm{x}$ - idade na data da avaliação; $\alpha$ - idade da aposentadoria programada; ma - morte de ativo; map - morte do aposentado; mp - morte de pensionista; $\omega$ - idade limite da tábua de mortalidade do servidor; $\omega \mathbf{j}$ - idade limite da tábua de mortalidade para o pensionista. 
Essa pensão será devida aos dependentes do servidor que hoje é ativo, que alcance a aposentadoria programada por idade, tempo de contribuição ou compulsória e venha a falecer durante a fruição do benefício. Ela pode ser representada pela tabela 6 é calculada pela equação 13:

$\left.V A P_{i, t}=\left({ }_{x} d_{x+a}\right)\left[{ }_{x+a} p_{x+n}\right) *\left(q_{x+n}^{i n v}\right)\right] * V S_{i, t} *\left({ }_{t} p_{0}\right)$, se $n \geq a$

$V S_{i, t}=\left\{\left[\left(\mathrm{VS}_{\mathrm{i}, 0}\right) *\left(\left(e^{(g+h)^{*} t}\right)-P P_{0}\right) *(0,7)\right]+P P_{0}\right\}$

$V S_{i, t}=\left\{\left[\left(\sum_{l=0,2^{*} a}^{a}\left(\left(V S_{i, 0}\right) *\left(e^{(g+h)^{* a}}\right) / 0,8 * a\right)-P P_{0}\right) *(0,7)\right]+P P_{0}\right\}$

onde:

$\mathrm{VS}_{\mathrm{i}, 0}$ - valor do salário do servidor $\mathrm{i}$, na data-base 0 ;

$\mathrm{h}$ - aumento geral dos salários decorrente do aumento da produtividade da economia;

g - aumento particular de salário, decorrente da progressão na carreira (tempo de serviço);

$\mathrm{t}$ - momento da projeção, em anos;

$\mathrm{n}$ - momento da morte do servidor;

a - momento da aposentadoria;

$\mathrm{x}$ - idade do servidor na data da avaliação;

0 - data-base da avaliação.

Aqui, da mesma forma que nas equações anteriores, as dimensões de tempo a serem analisadas estão ligadas a duas incertezas biométricas. A primeira dimensão de tempo está ligada à incerteza biométrica de falecimento do aposentado. Dado o falecimento do aposentado, a segunda dimensão de tempo deve ser analisada. Ela está ligada à incerteza biométrica do grupo familiar estar vivo. O valor de "n" na equação 13 inicia-se em "a" porque o benefício analisado só pode ser concedido após a aposentadoria do servidor, ou seja, " $n$ " precisa ser maior ou igual a "a", caso contrário o benefício não será concedido. 
A equação 13 apresenta um componente financeiro e outro biométrico e representa o valor esperado de pagamento futuro de benefício de pensão pela morte de um atual servidor ativo que alcance a aposentadoria programada e faleça durante a fruição da aposentadoria. O componente financeiro da pensão, para os servidores que ingressaram até 2003, incide sobre o valor da remuneração de um servidor ativo representado pela equação 13.1. Caso o servidor tenha entrado depois do ano de 2003 a equação que representa o seu componente financeiro é dado pela equação 13.2. Nesse caso o componente da pensão incidirá sobre a média aritmética simples de suas $80 \%$ maiores remunerações. Essas equações trazem o valor do benefício que o grupo familiar “j” terá, caso o servidor morra no momento "n" e o grupo familiar esteja vivo e recebendo a pensão até o momento " $\mathrm{t}$ ".

O valor do beneficio será equivalente a soma de duas parcelas, quais sejam: i) $70 \%$ da diferença entre a remuneração do servidor no momento da data-base e o valor do piso previdenciário, a remuneração será atualizada pela taxa de crescimento salarial $(\mathrm{g}+\mathrm{h})$; e ii) o valor do piso previdenciário.

O componente biométrico representa eventos probabilísticos que podem ocorrer em três períodos. O primeiro período analisado é o período contributivo do servidor entre as idades " $\mathrm{x}$ " $\mathrm{e}$ " $\mathrm{x}+\mathrm{a}$ ", onde se avalia a probabilidade do servidor permanecer em atividade $\left({ }_{x} d_{x+a}\right)$, ou seja, é o componente que fornece a probabilidade de ele não morrer, não se invalidar, tampouco se desligar do serviço público no período. O segundo período começa com a aposentadoria do servidor. Caso ele se aposente em "a", é necessário que se avalie a probabilidade do servidor continuar vivo e recebendo sua aposentadoria $\left({ }_{x+a} p_{x+n}\right)$, como também a probabilidade de ele falecer neste período $\left(q_{x+n}^{i n v}\right)$. Caso o servidor faleça em " $\mathrm{x}+\mathrm{n}$ ” é necessário que se avalie a probabilidade do grupo familiar “j” continuar vivo e recebendo o benefício após sua morte, até o momento de projeção $\left({ }_{0} p_{t}\right)$.

\subsubsection{Pensão do Servidor Ativo que se Aposente por Invalidez}

Essa pensão será devida aos dependentes do servidor que hoje é ativo, que se invalide e venha a falecer durante a fruição da aposentadoria por invalidez. Ela pode ser representada pela tabela 7 e calculada pelas equações $14 \mathrm{e} 14.1$. 
Tabela 7: Fluxo de Pensão do Servidor Ativo que se Aposente por Invalidez

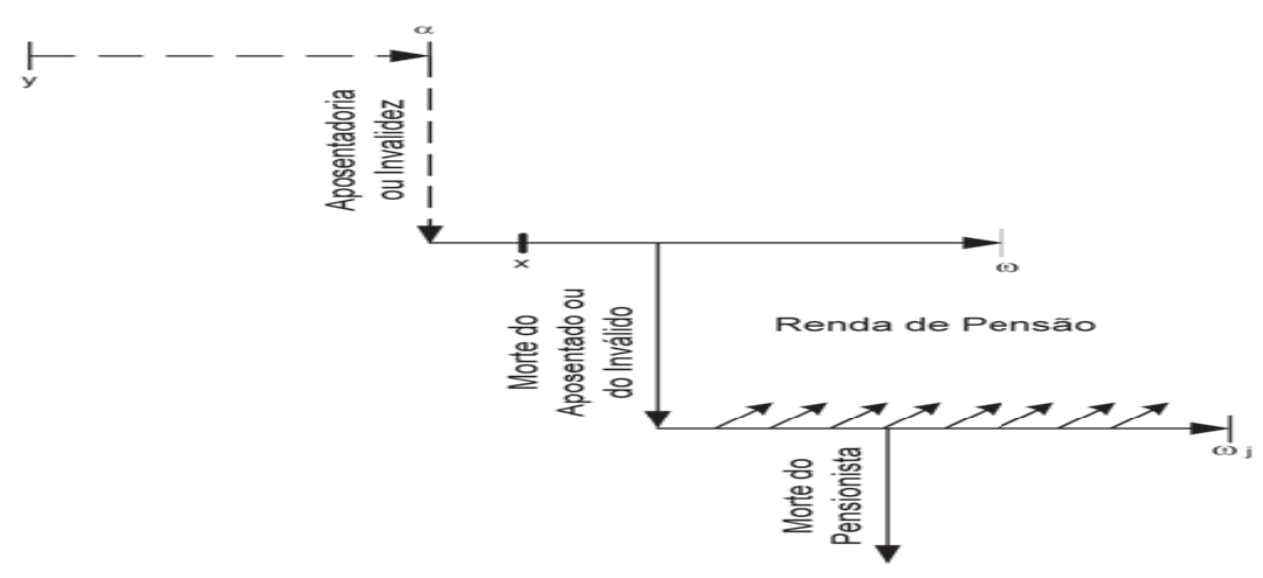

Fonte: FONTOURA, Francisco Robson da Silva. Avaliação da Solvência Econômico-Financeira de Entidades Municipais Gestoras de Regimes Próprios de Previdência Social.

Nota: $\mathrm{y}$ - idade de entrada no sistema; $\mathrm{x}$ - idade na data da avaliação; $\alpha$-idade da aposentadoria programada; $\omega$ - idade limite da tábua de mortalidade do servidor; $\omega \mathrm{j}$ - idade limite da tábua de mortalidade para o pensionista.

$V P I_{i, t}=\left({ }_{x} d_{x+k}\right) *\left(q_{x+k}^{i n v}\right) *\left({ }_{x+k} p_{x+n}\right) *\left(\mathrm{q}_{\mathrm{x}+\mathrm{n}}\right) *\left(\mathrm{VS}_{\mathrm{i}, \mathrm{t}}\right) *\left({ }_{0} p_{t}\right)$

$0<k \leq a-1$,

$V S_{i, t}=\left\{\left[\left(\mathrm{VS}_{\mathrm{i}, 0}\right) *\left(\left(e^{(g+h)^{*} t}\right)-P P_{0}\right) *(0,7)\right]+P P_{0}\right\}$

onde:

$\mathrm{VS}_{\mathrm{i}, 0}$ - valor do salário do servidor i, na data-base 0 ;

h - aumento geral dos salários decorrente do aumento da produtividade da economia;

g - aumento particular de salário, decorrente da progressão na carreira (tempo de serviço);

$\mathrm{t}$ - momento da projeção, em anos;

$\mathrm{k}$ - momento da entrada em invalidez do segurado;

$\mathrm{n}$ - momento da morte do segurado;

a - momento da aposentadoria;

x - idade do servidor na data da avaliação;

0 - data-base da avaliação. 
$\mathrm{Na}$ equação 14 as incertezas biométricas podem ser relacionadas a três dimensões do tempo. O período de permanência em validez do servidor ativo que se refere à primeira dimensão do tempo. Se o servidor se invalida, a segunda dimensão deve ser analisada. Ela está relacionada ao período de vida do servidor inválido. Caso o servidor inválido faleça, a última dimensão entra em análise e está vinculada ao período de vida do grupo familiar. O valor de " $k$ " esta limitado a "a-1", pois esse é o período limite de concessão do benefício, depois o servidor estará aposentado e não pode se enquadrar na condição de segurado ativo que se aposente por invalidez e faleça durante a fruição do benefício. A equação 14 apresenta um componente financeiro e outro biométrico. Eles representam o valor esperado de pagamento futuro de benefício de pensão pela morte de um atual servidor ativo que alcance a aposentadoria por invalidez e faleça durante a fruição da aposentadoria.

O componente financeiro é representado pela equação 14.1 e traz o valor do benefício que o grupo familiar "j" terá, caso o servidor morra no momento n e o grupo familiar esteja vivo e recebendo a pensão até o momento “ $t$ ”. Esse valor será equivalente a soma de duas parcelas, quais sejam: i) $70 \%$ da diferença entre a remuneração do servidor no momento da data-base e o valor do piso previdenciário, a remuneração será atualizada pela taxa de crescimento salarial $(\mathrm{g}+\mathrm{h})$; e ii) o valor do piso previdenciário.

O componente biométrico representa eventos probabilísticos que podem ocorrer em três períodos. O primeiro período analisado é o período contributivo do servidor de " $\mathrm{x}$ " até $\mathrm{o}$ momento " $\mathrm{x}+\mathrm{k}$ " em que se avalia a probabilidade do servidor permanecer em atividade $\left({ }_{x} d_{x+k}\right)$, ou seja, é o componente que fornece a probabilidade de ele não morrer, não se invalidar, tampouco se desligar do serviço público. Nesse período é avaliada também a probabilidade do servidor se invalidar na idade " $\mathrm{x}+\mathrm{k}$ ", $\left(q_{x+k}^{\text {inv }}\right)$. O segundo período começa com a entrada em invalidez do servidor. Caso ele se invalide na idade " $\mathrm{x}+\mathrm{k}$ " é necessário que se avalie a probabilidade do servidor continuar vivo e recebendo sua aposentadoria por invalidez $\left({ }_{x+k} p_{x+n}\right)$, como também a probabilidade dele falecer neste período $\left(\mathrm{q}_{\mathrm{x}+\mathrm{n}}\right)$. Caso o servidor faleça na idade “ $\mathrm{x}+\mathrm{n}$ " é necessário que se avalie a probabilidade do grupo familiar "j" continuar vivo e recebendo o benefício após sua morte, até o momento de projeção " $\mathrm{t}$ ” $\left({ }_{0} p_{t}\right)$.

\subsubsection{Pensão de Servidor Inativo}


Essa pensão será devida aos dependentes do segurado que hoje é inativo (aposentado programado ou por invalidez) que venha a falecer durante a fruição do benefício. Ela pode ser representada pela tabela 8 é calculada pela equação 15 :

\section{Tabela 8: Fluxo de Pensão do Inativo}

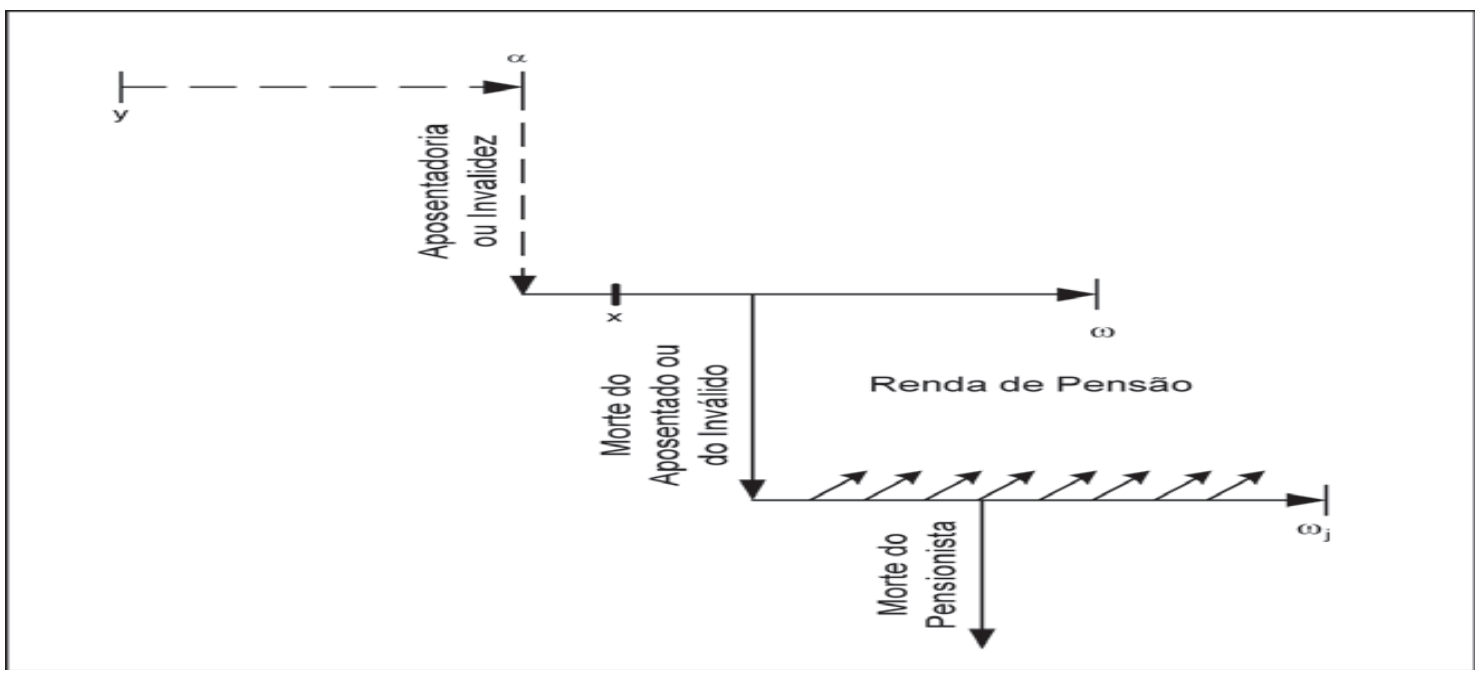

Fonte: FONTOURA, Francisco Robson da Silva. Avaliação da Solvência Econômico-Financeira de Entidades Municipais Gestoras de Regimes Próprios de Previdência Social.

Nota: $\mathrm{y}$ - idade de entrada no sistema; $\mathrm{x}$ - idade na data da avaliação; $\alpha$ - idade da aposentadoria programada; $\omega$ - idade limite da tábua de mortalidade do servidor; $\omega j$ - idade limite da tábua de mortalidade para o pensionista.

$V S I_{i, t}=\left({ }_{x} d_{x+n}\right) *\left(\mathrm{q}_{\mathrm{x}+\mathrm{n}}\right) *\left(\mathrm{VS}_{\mathrm{i}, \mathrm{t}}\right) *\left({ }_{0} p_{t}\right)$

$n \geq a_{j}$,

$$
\begin{aligned}
& V S_{i, t}=\left\{\left[\left(\mathrm{VS}_{\mathrm{i}, 0}\right) *\left(\left(e^{(g+h)^{* t}}\right)-P P_{0}\right) *(0,7)\right]+P P_{0}\right\} \\
& V S_{i, t}=\left\{\left[\left(\sum_{l=0,2^{*} a}^{a}\left(\left(V S_{i, 0}\right) *\left(e^{(g+h)^{*} a}\right) / 0,8 * a\right)-P P_{0}\right) *(0,7)\right]+P P_{0}\right\}
\end{aligned}
$$

onde:

$\mathrm{VS}_{\mathrm{i}, 0}-$ valor do salário do servidor i, na data-base 0 ;

$\mathrm{h}$ - aumento geral dos salários decorrente do aumento da produtividade da economia;

g - aumento particular de salário, decorrente da progressão na carreira (tempo de serviço); 
$\mathrm{t}$ - momento da projeção, em anos;

$\mathrm{n}$ - momento da morte do servidor aposentado $\mathrm{i}$;

$\omega$ - idade limite da tábua de mortalidade do servidor;

a - momento da aposentadoria;

$\mathrm{x}$ - idade do servidor na data da avaliação;

0 - data-base da avaliação.

O último caso de pensão a conceder refere-se ao segurado inativo que venha a falecer. A equação 15 apresenta duas dimensões do tempo: a primeira dimensão de tempo está ligada à incerteza biométrica de falecimento do aposentado. Caso o aposentado faleça, a segunda dimensão de tempo deve ser analisada. Ela está ligada à incerteza biométrica do grupo familiar estar vivo. Nela temos que $\mathrm{n} \geq \mathrm{a}$, pois nesse caso somente se o servidor for inativo haverá pagamento de pensão. A equação apresenta um componente financeiro e outro biométrico e representa o valor esperado de pagamento futuro de benefício de pensão pela morte de um atual servidor aposentado.

O componente financeiro da pensão, para os servidores que ingressaram até 2003, incide sobre o valor da remuneração de um servidor ativo representado pela equação 15.1. Caso o servidor tenha entrado depois do ano de 2003 a equação que representa o seu componente financeiro é dado pela equação 15.2. Nesse último caso o componente da pensão incidirá sobre a média aritmética simples de suas $80 \%$ maiores remunerações. Essas equações trazem o valor do benefício que o grupo familiar "j” terá, caso o servidor morra no momento "n" e o grupo familiar esteja vivo e recebendo a pensão até o momento " $\mathrm{t}$ ".

O valor da pensão será equivalente a soma de duas parcelas, quais sejam: i) $70 \%$ da diferença entre a remuneração do servidor no momento da data-base e o valor do piso previdenciário, a remuneração será atualizada pela taxa de crescimento salarial $(\mathrm{g}+\mathrm{h})$; e ii) o valor do piso previdenciário.

O componente biométrico representa eventos probabilísticos que podem ocorrer em dois períodos. O primeiro período analisado é o período de fruição da aposentadoria do servidor, onde se avalia a probabilidade do servidor sobreviver $\left({ }_{x} d_{x+n}\right)$. Nesse período é analisada também a probabilidade do aposentado falecer $\left(\mathrm{q}_{\mathrm{x}+\mathrm{n}}\right)$ em uma idade " $\mathrm{x}+\mathrm{n}$ ". 
Caso o servidor faleça em " $\mathrm{x}+\mathrm{n}$ ”, é necessário que se avalie a probabilidade do grupo familiar " $\mathrm{j}$ " continuar vivo e recebendo o benefício após sua morte, até o momento " $\mathrm{t}$ " da projeção $\left({ }_{0} p_{t}\right)$. 


\section{Estimação dos Fluxos Financeiros no Fundo}

Para calcularmos os fluxos de contribuições e benefícios dos servidores será necessário obter a projeção de salários que serão recebidos durante a vida ativa, a expectativa de vida no momento da aposentadoria e os riscos associados. Esse capítulo está dividido em quatro seções. Na seção 5.1 apresentamos as principais hipóteses adotadas por esse trabalho possibilitando assim a estimação dos fluxos financeiros no Fundo. Na seção 5.2 estimamos as remunerações dos servidores. Na seção 5.3 mostramos como calculamos as médias de idade, tempo de serviço e tempo de benefícios dos servidores. E, finalmente, na seção 5.4, descrevemos quais são as contribuições arrecadadas e os benefícios pagos pelo sistema previdenciário pós-criação do Fundo previdenciário federal.

\subsection{Hipóteses adotadas}

Para calcularmos os fluxos financeiros no Fundo precisaremos adotar algumas hipóteses. Isso acarretará algumas limitações nos resultados, mas não implicará em alterações nos principais resultados que são bastante robustos.

A primeira hipótese adotada foi sobre a idade de ingresso dos servidores público federais. Tínhamos, inicialmente, a partir dos dados do MPOG (Ministério planejamento e Orçamento) apenas a idade média. Para sabermos as idades de ingresso no serviço público supomos que a idade de entrada no serviço público federal tem uma distribuição normal, que sabemos necessitar de dois parâmetros, quais sejam, a média e o desvio padrão. O desvio padrão nós calculamos a partir dos dados da PNAD 2005 (última PNAD disponível naquele momento) e consideramos constantes, ou seja, igual para todas as categorias. A simplificação aqui parece bastante consistente, pois a diferença de idade de ingresso permanece entre os servidores.

A segunda hipótese refere-se às pensões. Primeiro precisamos saber se o servidor, ativo ou inativo, deixará pensão. Segundo de quantos anos será essa pensão. Assumiremos nesse trabalho que apenas os homens deixarão pensão e ela será de cinco anos. Cinco anos correspondem à duração média das pensões no Brasil (ZYLBERSTAJN, 2006). 
A terceira hipótese adotada é sobre a expectativa de vida no momento da aposentadoria considerada igual às estimativas de expectativa de vida fornecidas pela Tábua de Mortalidade do Instituto Brasileiro de Geografia e Estatística (IBGE) de 2005 para o sexo masculino e feminino.

A quarta hipótese adotada é sobre o percentual de contribuição destinada a cobrir as aposentadorias de risco - aposentadorias resultantes de morte e invalidez. Nesse trabalho assumiremos uma alíquota de contribuição conservadora ${ }^{3}$, para os riscos previdenciários e administração do fundo, de $2 \%$. Sendo $1 \%$ pago pelo servidor e $1 \%$ pago pelo governo.

\subsection{Hipóteses adotadas}

Para calcularmos os fluxos financeiros no Fundo precisaremos adotar algumas hipóteses. Isso acarretará algumas limitações nos resultados, mas não implicará em alterações nos principais resultados que são bastante robustos.

A primeira hipótese adotada foi sobre a idade de ingresso dos servidores público federais. Tínhamos, inicialmente, a partir dos dados do MPOG (Ministério planejamento e Orçamento) apenas a idade média. Para sabermos as idades de ingresso no serviço público supomos que a idade de entrada no serviço público federal tem uma distribuição normal, que sabemos necessitar de dois parâmetros, quais sejam, a média e o desvio padrão. O desvio padrão nós calculamos a partir dos dados da PNAD 2005 (última PNAD disponível naquele momento) e consideramos constantes, ou seja, igual para todas as categorias. A simplificação aqui parece bastante consistente, pois a diferença de idade de ingresso permanece entre os servidores.

A segunda hipótese refere-se às pensões. Primeiro precisamos saber se o servidor, ativo ou inativo, deixará pensão. Segundo de quantos anos será essa pensão. Assumiremos

\footnotetext{
3 Por exemplo, Oliveira, Beltrão e Pasinato (1999) e Instituto Liberal (1991), consideram razoável uma alíquota de $2,5 \%$ do salário para cobertura dos benefícios precoces relacionados à invalidez e morte. Oliveira, Beltrão e Pasinato (1999) consideram, ainda, 1\% a título de custos de administração. Mas nesses trabalhos a alíquota seria para o pagamento de todo o beneficio e nesse, ao contrário, ela será apenas para pagar a diferença entre o valor da remuneração é o do piso previdenciário, portanto uma alíquota de $2 \%$ mostra-se relativamente conservadora.
} 
nesse trabalho que apenas os homens deixarão pensão e ela será de cinco anos. Cinco anos correspondem à duração média das pensões no Brasil (ZYLBERSTAJN, 2006).

A terceira hipótese adotada é sobre a expectativa de vida no momento da aposentadoria considerada igual às estimativas de expectativa de vida fornecidas pela Tábua de Mortalidade do Instituto Brasileiro de Geografia e Estatística (IBGE) de 2005 para o sexo masculino e feminino.

A quarta hipótese adotada é sobre o percentual de contribuição destinada a cobrir as aposentadorias de risco - aposentadorias resultantes de morte e invalidez. Nesse trabalho assumiremos uma alíquota de contribuição conservadora ${ }^{4}$, para os riscos previdenciários e administração do fundo, de $2 \%$. Sendo $1 \%$ pago pelo servidor e $1 \%$ pago pelo governo.

\subsection{Estimação dos Fluxos de Salários}

Para estimar o fluxo das remunerações utilizamos a PNAD 2005. Para tanto fizemos uma regressão linear para todos os servidores federais com rendimentos positivos. A partir das regressões estimamos, por Mínimos Quadrados Ordinários (MQO), os rendimentos em função da escolaridade (anos de estudo), dummies (para gênero e raça), experiência no mercado de trabalho (medida em anos) e uma dummie de gênero interagindo com a experiência para captar os diferentes retornos entre homens e mulheres. A experiência no mercado de trabalho é a variável mais relevante para os nossos propósitos. A variável dependente é o logaritmo da renda no trabalho principal.

O coeficiente estimado para a variável experiência no mercado de trabalho expressa o impacto nos rendimentos do trabalho causados por um ano adicional de experiência no mercado de trabalho. Para a PNAD 2005, o coeficiente estimado mostra que os rendimentos do trabalho crescem em média 3,7\% para os homens e 1,4\% para as mulheres a cada ano trabalhado. Além disso, ele mostra que há uma diferença enorme na forma como a experiência afeta os rendimentos quando comparamos servidores

\footnotetext{
${ }^{4}$ Por exemplo, Oliveira, Beltrão e Pasinato (1999) e Instituto Liberal (1991), consideram razoável uma alíquota de $2,5 \%$ do salário para cobertura dos benefícios precoces relacionados à invalidez e morte. Oliveira, Beltrão e Pasinato (1999) consideram, ainda, 1\% a título de custos de administração. Mas nesses trabalhos a alíquota seria para o pagamento de todo o beneficio e nesse, ao contrário, ela será apenas para pagar a diferença entre o valor da remuneração é o do piso previdenciário, portanto uma alíquota de $2 \%$ mostra-se relativamente conservadora.
} 
públicos e trabalhadores da iniciativa privada (os valores estimados para trabalhadores da iniciativa privada ficam na em torno de $1,3 \%$ ).

Esses resultados são pioneiros. Pois os trabalhos sobre previdência, via de regra, não consideram a diferença entre a experiência dos homens e das mulheres e ademais muitas vezes não diferenciam servidores estatutários de funcionários públicos e estes de funcionários da iniciativa privada ${ }^{5}$. Os ganhos derivados dessa diferenças entre experiência de homens e mulheres são enormes, para esse trabalho e os próximos que vierem a trabalhar com um sistema de capitalização, pois os valores dos benefícios são calculados de acordo com o montante acumulado. Assim crescimentos de remunerações diferentes geram benefícios diferentes. Em particular, o crescimento de remuneração maior para servidores do que para servidoras irá gerar rendimentos maiores para os servidores. Isso não ocorre no sistema de repartição, sistema previdenciário atual, que calcula o valor do beneficio de acordo com a lei que equipara os rendimentos entre servidores e servidoras.

Tabela 9 :Regressão do logaritmo da renda no trabalho principal

\begin{tabular}{lcc}
\hline Variável & Coeficiente & Estatística t \\
\hline Intercepto & 5.655 & 26.77 \\
Experiência & 0.0368 & 22.63 \\
\hline & & \\
\hline Experiência*Mulher & -0.022 & -6.98 \\
Mulher & 0.306 & 5.49 \\
Não Branco & -0.140 & -4.84 \\
Educação & 0.087 & 5.50 \\
Idade que começou a trabalhar & -0.042 & -3.27 \\
Idade*educação & 0.0041 & 4.37 \\
\hline Número de Observações & 2.346 & \\
$\mathrm{R}^{2}$ & 0.441 & \\
\hline
\end{tabular}

\footnotetext{
${ }^{5}$ Servidores públicos são estatutários. Funcionários públicos são CLTs. Os primeiros são regidos pela lei 8112/92 e têm estabilidade além de participarem do RPPS. Já os funcionários públicos são regidos pela Consolidação Leis Trabalhistas (CLT), com pequenas adaptações, e não têm estabilidade e participam do RGPS.
} 
Conhecendo os rendimentos do trabalho principal em 2007, a idade em que cada pessoa começou a trabalhar e tendo-se a taxa estimada de crescimento é possível calcular o rendimento esperado a cada ano t, até o momento da aposentadoria. Sendo dado por:

$W_{t}=W_{0} e^{(h+g+0,5 * S E) * t}$

Onde:

$\mathrm{W}^{0}$ - remuneração do servidor no momento base;

$\mathrm{h}=$ taxa de aumento geral dos salários do setor público que, por hipótese, vamos supor igual ao aumento da produtividade da economia;

$\mathrm{g}$ - é igual ao crescimento da remuneração anual, 3,6\% se homem e 1,4\% se mulher;

SE - é o termo de correção do logaritmo para o valor em nível (Wooldridge, 2002).

Para cada indivíduo na amostra o tempo total no mercado de trabalho corresponde à diferença entre a idade em que o indivíduo começou a trabalhar e a idade prevista para a aposentadoria. Dada a sua idade e a tabela de mortalidade, podemos indicar sua idade esperada de aposentadoria.

\subsection{Tempo de Contribuição e Recebimento de Benefícios}

Nesta seção mostraremos como foram calculados o tempo de contribuição dos servidores e o tempo que ele e seus dependentes receberão os benefícios. Esses valores são muito importantes para as Contas Pessoais de Aposentadoria (CPA), pois o tempo de contribuição e benefício é um fator determinante no valor da mensalidade paga. A mensalidade da CPA é determinada pelo saldo acumulado durante as contribuições da vida ativa e a expectativa de vida do servidor no momento de sua aposentadoria.

Inicialmente simulamos a idade de entrada dos servidores federais para um determinado ano, 2007. A partir dos dados do Ministério de Planejamento e da PNAD e das hipóteses adotadas, descritas na seção 5.1, foi possível obter a média e o desvio padrão, respectivamente, para os servidores federais e então simular a idade de ingresso no serviço publico federal para cada cargo.

Para determinar o tempo de serviço calculamos a diferença entre a idade de ingresso do servidor e o tempo necessário, legalmente, para sua aposentadoria. Para calcular a 
expectativa de vida no momento da aposentadoria utilizamos as estimativas de expectativa de vida fornecidas na Tábua de Mortalidade do Instituto Brasileiro de Geografia e Estatística (IBGE) de 2005 (última tabela disponível) para o sexo masculino e feminino. A tabela abaixo representa, de forma mais geral, esses eventos para algumas carreiras do executivo de acordo com a idade média de ingresso no serviço publico federal.

Tabela 10: Idade de Ingresso, Aposentadoria, Expectativa de vida e Tempo de contribuição e Sobrevida para homens e mulheres respectivamente

\begin{tabular}{|l|c|c|c|c|c|}
\hline Carreira & Ingresso & Aposentadoria & $\begin{array}{l}\text { Tempo de } \\
\text { contribuição }\end{array}$ & $\begin{array}{l}\text { Expectativa de } \\
\text { vida }\end{array}$ & Sobrevida \\
\hline Gestão & 33 & $65-63$ & $32-30$ & $73,3-78,8$ & $8,3-15,8$ \\
\hline Auditoria & 30 & $65-60$ & $35-30$ & $72,9-78,6$ & $7,9-18,6$ \\
\hline Diplomacia & 27 & $62-57$ & $35-30$ & $72,4-78,5$ & $10,4-21,5$ \\
\hline Jurídica & 28 & $63-58$ & $35-30$ & $72,6-78,5$ & $9,6-20,5$ \\
\hline $\begin{array}{l}\text { Polícia } \\
\text { Federal }\end{array}$ & 30 & $65-60$ & $35-30$ & $72,9-78,6$ & $7,9-18,6$ \\
\hline Docente & 35 & $65-60$ & $30-25$ & $73,6-78,9$ & $8,6-18,9$ \\
\hline Regulação & 32 & $65-60$ & $33-28$ & $73,1-78,8$ & $8,1-18,8$ \\
\hline
\end{tabular}

Fonte: Elaboração própria.

A tabela apresenta em cada célula a idade de aposentadoria, tempo de contribuição, expectativa de vida e sobrevida para homens e mulheres, respectivamente. Podemos observar enormes diferenças de sobrevida para homens e mulheres, mais do que o dobro para mulheres. Essa diferença é motivada por duas outras variáveis, tempo de contribuição e expectativa de vida. A primeira delas decorre de dispositivo legal, a mulher aposentará com 5 anos a menos do que o homem - essa regra vale tanto para o tempo de contribuição quanto para a idade mínima. A segunda variável diz respeito à expectativa de vida que é em média 5 ou 6 anos maior para as mulheres. A partir do exposto na tabela acima fica claro que um sistema de capitalização deve tender a favorecer os servidores do sexo masculino. Pois esses, além de contribuírem por um período maior, apresentam uma sobrevida menor, duas variáveis relevantes no cálculo do valor da aposentadoria no sistema de capitalização.

Não obstante, o período total de recebimento de benefícios não se resume apenas a vida do aposentado. Após a morte do servidor, há o período de pensão que ele deixará para o pensionista indicado antes de sua morte. Nesse trabalho assumimos que para os 
benefícios programados apenas os homens deixam pensão, pois, via de regra, a expectativa de vida do homem é menor do que a da mulher. Assumiremos que os homens pagam pensão por um período de cinco anos conforme descrito na seção 5.1.

\subsection{Contribuições para o Fundo Federal e Benefícios pagos pelo Fundo Federal}

A receita previdenciária do Regime Próprio dos Servidores Públicos Federais da União, atualmente, é composta de uma alíquota de $11 \%$ incidente sobre a remuneração do servidor. A partir da criação do Fundo incidirão duas alíquotas sobre as remunerações que excederem o piso previdenciário. Até o valor do piso a alíquota do servidor será de $11 \%$ e acima do piso de até $7,5 \%$. A formulação matemática desta contribuição pode ser encontrada abaixo.

$V C_{i, t}=V E_{i, t} * T x \%$

onde,

$V C_{i, t}-$ Valor da Contribuição do servidor i, no momento t;

$V E_{i, t}-$ Valor do Salário Esperado de contribuição do servidor i, no momento t;

Tx\% - Taxa Percentual de Contribuição.

O valor da contribuição do servidor em cada momento do tempo " $\mathrm{t}$ " pode ser encontrado pela aplicação da alíquota de contribuição sobre o valor do salário que se espera que o servidor alcance em cada momento do tempo. Esse salário de contribuição pode ser encontrado da seguinte maneira:

$V E_{i, t}=V S_{i, t}{ }_{t} d_{x}$

$\mathrm{O}$ valor esperado do salário no momento " $\mathrm{t}$ " vai ser igual ao salário naquele momento ponderado pela probabilidade de permanência do servidor $\left({ }_{t} d_{x}\right)$ no serviço público, ou seja, é o valor da remuneração do servidor caso ele permaneça vivo, válido e não se desligue do serviço público até o período da projeção. O valor do Salário $V S_{i, t}$ pode ser encontrado por:

$V S_{i, t}=V S_{i, 0} * e^{(g+h)^{*} t}$ 
O valor do salário no momento " $\mathrm{t}$ " é igual ao salário do servidor na data-base da avaliação, atualizado pelo crescimento salarial $(\mathrm{g}+\mathrm{h})$ até o momento da projeção $(\mathrm{t})$.

Assim, pode-se encontrar o valor da receita de contribuições em cada momento da projeção. A alíquota de contribuição da União será a mesma alíquota de contribuição do servidor, de acordo com a legislação previdenciária.

Os benefícios de cada servidor serão funções de suas contribuições. Assim temos dois casos a analisar: i) o servidor contribui durante todo o período laborativo, ou seja, não morre, e não entra em invalidez é não se desliga; e ii) o servidor não contribui durante todo o período laborativo por uma das razões descritas anteriormente. Iremos analisar o primeiro caso. O segundo caso, morte e invalidez e desligamento, são os benefícios de risco que devem ser financiados pelos servidores que estão contribuindo. Assim uma parte de sua contribuição será destinada a cobrir essas aposentadorias resultantes de morte e invalidez. Nesse trabalho assumiremos, conforma descrito na seção 5.1, uma alíquota de contribuição conservadora, para os riscos previdenciários e administração do fundo, de $2 \%$. Sendo $1 \%$ pago pelos servidores e $1 \%$ pago pelo governo. Assumindo essa hipótese conservadora podemos subestimar levemente o valor dos benefícios, mas isso não influenciará nos resultados finais que são bastante robustos, ou seja, não são influenciados por pequenas variações nos valores dos benefícios.

A partir do texto legal e do projeto de lei do Fundo Federal ${ }^{6}$ teremos três situações distintas para os servidores federais que irá implicar em pagamentos de benefícios diferenciados:

a) o servidor que ingressar na administração pública federal após a criação do Fundo fará jus, obrigatoriamente, a uma aposentadoria equivalente ao saldo acumulado no Fundo adicionado do teto do regime geral de previdência privada. Para isso deverá contribuir com uma alíquota de $11 \%$ sobre o teto do regime geral de previdência e mais uma alíquota de até $7,5 \%$,sobre a diferença entre a sua remuneração e o teto do regime geral. O governo contribuirá com uma alíquota equivalente a do servidor;

\footnotetext{
${ }^{6}$ Ver anexo 3.
} 
b) o servidor que ingressou na administração pública federal entre o fim do ano de 2003 e o inicio da criação do Fundo poderá optar entre o seu sistema de beneficio atual, ele receberá a média aritmética das $80 \%$ maiores remunerações, ou migrar para o Fundo. Se migrar para o Fundo irá receber o seu saldo acumulado adicionado do teto do regime geral de previdência e de mais um beneficio especial, que é uma função de quantos anos ele possui de contribuição no serviço público federal no momento de sua migração. A fim de receber o beneficio do sistema atual deverá contribuir com uma alíquota de $11 \%$ sobre sua remuneração. Já para receber o beneficio do Fundo deverá contribuir com uma alíquota de $11 \%$ sobre o teto do regime geral de previdência e mais uma alíquota de até $7,5 \%$ sobre a diferença entre a sua remuneração e o teto do regime geral. $\mathrm{O}$ governo contribuirá com uma alíquota equivalente a do servidor;

c) o servidor que ingressou no serviço público federal antes de 2003 poderá optar entre seu sistema atual - que paga aposentadoria integral, ou seja, sua ultima remuneração mais a equiparação com os servidores da ativa - ou migrar para o Fundo. Migrando para o Fundo fará jus a uma aposentadoria equivalente ao seu saldo acumulado no fundo adicionado do teto do regime geral de previdência e do beneficio especial que é uma função de seu tempo de serviço na administração pública federal. Para o seu sistema atual, nesse caso aposentadoria integral, deverá contribuir com uma alíquota de 11\% sobre sua remuneração. Se migrar para o Fundo deverá contribuir com uma alíquota de $11 \%$ sobre o teto do regime geral de previdência e mais uma alíquota de ate 7,5\% sobre a diferença entre a sua remuneração e o teto do regime geral. O governo contribuirá com uma alíquota equivalente a do servidor;

A partir do exposto acima, é necessário fazer duas observações:

i) apesar de o servidor receber a média aritmética das $80 \%$ maiores remunerações no caso "b" e a sua última remuneração no caso "c", ele obrigatoriamente deve contribuir para o Regime Geral de Previdência Publica com uma alíquota de 11\% sobre os valores que excederem o piso previdenciário. Portanto o servidor recebe apenas 0,89 do valor declarado como sua aposentadoria. É esse valor que deve ser considerado na sua tomada de decisão sobre qual sistema deverá optar, ou seja, se permanece no atual sistema ou migra para o Fundo; 
ii) a migração do servidor para o Fundo no caso "b" e "c" implica imediatamente em uma redução na sua contribuição para a previdência de 3,5\%, diferença entre a alíquota antiga de $11 \%$ e a nova alíquota de $7,5 \%$. Essa redução na contribuição é aplicada sobre a diferença entre sua remuneração e o teto do regime geral de previdência. Esse valor deverá ser capitalizado no sistema de aposentadoria do Fundo para efeito de tomada de decisão do servidor, pois isso irá gerar um aumento na sua renda liquida mensal. 


\section{Principais resultados do sistema previdenciário federal após a criação do Fundo}

\section{Federal}

Neste capítulo apresentaremos os principais resultados do sistema previdenciário federal supondo a criação do Fundo Federal nos moldes que foi enviado ao Congresso $\mathrm{Nacional}^{7}$. Para descrevermos os resultados iremos supor quatro cenários: cenário $\mathrm{A}$, otimista, com taxas de juro real de $6 \%$ ao ano; cenário $\mathrm{B}$, intermediário, com taxas de juro real de 4,5\% ao ano; e cenário $\mathrm{C}$, conservador, com taxas de juro real de $3 \%$ ao ano. Adicionalmente faremos um quarto cenário bastante conservador, com taxas de juro real de apenas 2,5\%. Esse cenário será uma espécie de limite inferior para as taxas de juros.

$\mathrm{Na}$ seção 6.1 mostraremos como foram construídos os gráficos para descrever os benefícios previdenciários nos sistemas previdenciários; na seção 6.2 mostramos os resultados para os servidores supondo os quatro cenários descritos acima e na seção 6.3 mostraremos os resultados para as servidoras, também, supondo os quatro cenários descritos acima.

\subsection{Benefícios e contribuições dos sistemas previdenciários}

Utilizando os benefícios e as taxas de contribuição descrito no capítulo 4 e as hipótese adotadas no capitulo 5 construímos os fluxos de benefícios para uma única coorte para o ano de 2007. A partir dos gráficos apresentados teremos os valores dos benefícios previdenciários. Os gráficos abaixo relacionam idade de ingresso no serviço público, eixo " $\mathrm{x}$ ", com o valor da aposentadoria no eixo " $\mathrm{y}$ ”. No titulo do gráfico temos o valor da remuneração do servidor no momento em que ele ingressa no serviço publico. Os benefícios descritos são para os atuais servidores é para os servidores que entrarão após a criação do Fundo.

Para os atuais servidores temos dois casos:

\footnotetext{
${ }^{7}$ Projeto encontra-se no anexo 3 na integra.
} 
i) Ap Atual: Equivale ao valor da aposentadoria para os servidores que entraram no serviço publico após o ano de 2003. Ela é calculada pela media aritmética das $80 \%$ maiores remunerações do servidor;

ii) Ap Integral: Equivale ao valor da aposentadoria para os servidores que entram no serviço publico até o ano de 2003 e é equivalente ao seu ultimo salário na ativa.

Para os servidores que entrarão depois da criação do Fundo ou migrarem para o Fundo, voluntariamente, receberão o seguinte valor:

i) Ap Fundo: Equivale ao valor que ele efetivamente vai receber, ou seja, o valor acumulado no período adicionado do valor do teto da previdência social. Para os servidores que migrarem tem-se ainda um adicional de 3,5\% que deixou de pagar como alíquota e de um beneficio especial que é função positiva de seu tempo de contribuição no serviço publico federal. O benefício especial ${ }^{8}$ deve compensar o valor menor do beneficio que será recebido por aqueles servidores que migrarem para o Fundo. Os servidores que migrarem contribuirão menos tempo, gerando, conseguintemente, menor saldo acumulado que, por sua vez, irá gerar menor beneficio.

\subsection{Valores dos benefícios para os servidores de acordo com cenários adotados (homens)}

Os gráficos abaixo foram simulados para quatro taxas de juros diferentes, mantendo as demais variáveis constantes. Em primeiro lugar fizemos uma simulação para um cenário otimista com taxa de juros real de $6 \%$ ao ano e remunerações de $\mathrm{R} \$ 3764$, $\mathrm{R} \$ 10832$ e R\$ 21000 que são respectivamente os gráficos 2, 3 e 4.

\footnotetext{
${ }^{8}$ Essa regra esta descrita no anexo 3.
} 
A observação desses gráficos revela que, em termos mais gerais, a aposentadoria integral "Ap Integral" traz os maiores benefícios para os servidores e isso independente da idade que eles ingressam no serviço publico federal, a exceção fica por conta dos servidores que recebem remunerações mais elevadas e possuem aproximadamente 34 anos de idade. Esse último efeito ocorre devido ao sistema de capitalização do Fundo que provoca um comportamento típico, observado em todos os gráficos, para os valores dos benefícios de acordo com a idade de ingresso do servidor público.

\section{Gráfico 2 - Remuneração R\$ 3764}

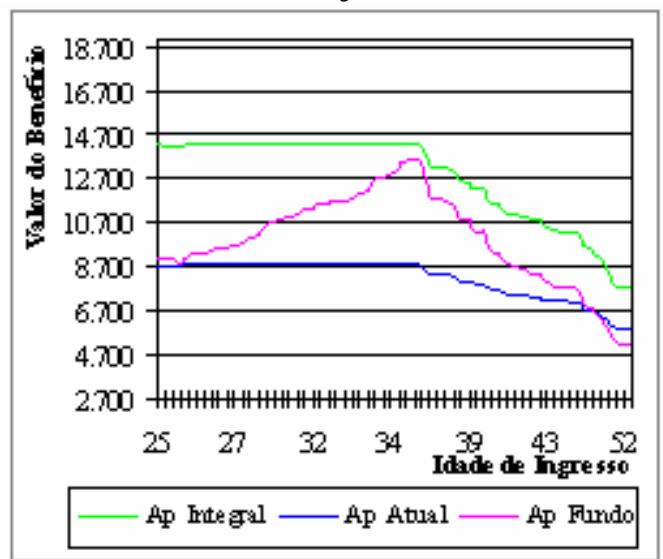

Elaboração Própria

\section{Gráfico 3 - Remuneração R\$ 10832}

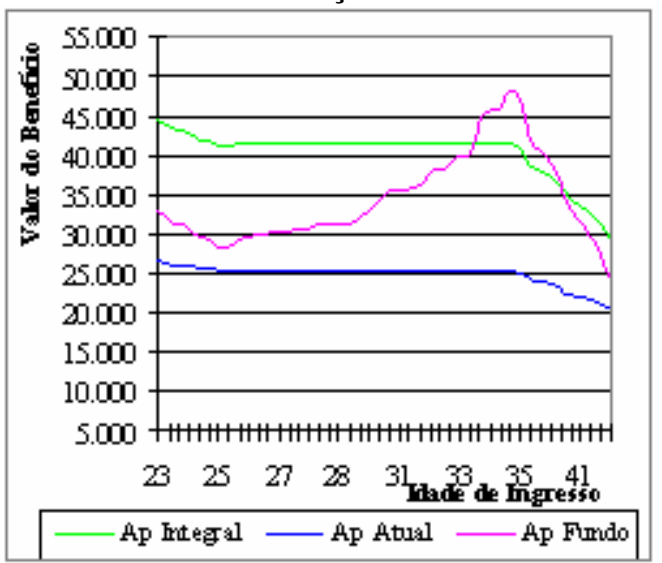

Elaboração própria

\section{Gráfico 4 - Remuneração R\$ 21000}

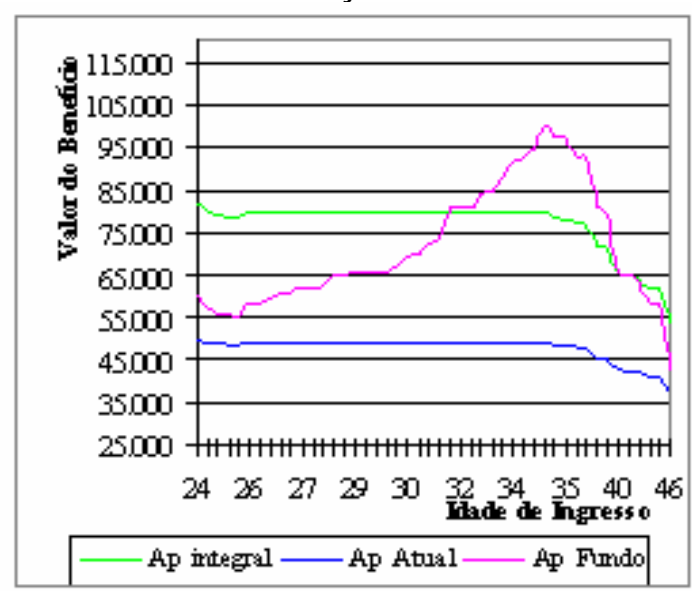

Elaboração própria

Para os servidores que ingressam com idade de 18 até os 25 anos de idade há decréscimo nos valores dos benefícios, basta observar a linha "Ap Fundo" nos gráficos. Nesse caso reduz-se o tempo de contribuição do servidor e ao mesmo tempo sua sobrevida, ou seja, o tempo de recebimento de benefícios. Mas como o tempo de 
contribuição domina a sobrevida em termos financeiros temos o decréscimo dos benefícios.

Já para os servidores que ingressaram com idade entre 25 e 35 anos temos um acréscimo nos valores dos benefícios à medida que a idade de ingresso dos servidores aumenta. $\mathrm{O}$ aumento dos valores dos benefícios ocorre porque o tempo de contribuição permanece constante e a sobrevida reduz com o aumento da idade de ingresso: o servidor que ingressa com 25 anos aposenta com 60 anos, idade mínima; e o servidor que ingressa com 35 anos de idade aposenta com 70 anos, idade máxima; mas nos dois casos há contribuição de 35 anos. Uma redução da sobrevida mantida constante os valores de contribuição aumenta o valor dos benefícios como descrito nos gráficos acima.

Finalmente para os servidores que ingressaram após os 35 anos de idade há decréscimos dos valores dos benefícios à medida que a idade de ingresso aumenta. Esse efeito é provocado pela redução do tempo de contribuição e redução da sobrevida. Como o valor financeiro do tempo de contribuição é sempre dominante sobre o valor financeiro da sobrevida temos a redução do valor do benefício.

Quando comparamos o valor dos benefícios dos servidores que ingressaram após o ano de 2003 e antes da criação do Fundo e não migraram para o Fundo "Ap Atual" com o valor dos benefícios dos servidores que vierem a migrar para o Fundo "Ap Fundo" podemos observar claramente que aqueles servidores que migrarem para o Fundo receberão maiores benefícios, independente da idade de ingresso.

Em resumo, a partir da leitura dos gráficos, e considerando uma taxa de juros real de 6\% ao ano chegamos a dois resultados distintos: o primeiro resultado é que os servidores que recebem aposentadoria integral, ingressantes antes de 2003, não devem migrar para o Fundo; e o segundo é que servidores que não recebem aposentadoria integral, ingressaram depois de 2003, devem, na sua maioria, migrar para o Fundo.

O cenário intermediário, com taxas de juro real de 4,5\% ao ano, e remunerações de $\mathrm{R} \$$ 3764, R\$ 10832 e R\$ 21000 é representado, respectivamente, pelos gráficos 5, 6 e 7. 
Os gráficos mostram que os benefícios decorrentes da aposentadoria integral, “Ap Integral", é superior aos benefícios dos servidores que recebem benefícios do Fundo "Ap Fundo" e dos servidores que recebem benefícios do sistema atual "Ap Atual".

Gráfico 5 - Remuneração R\$ 3764

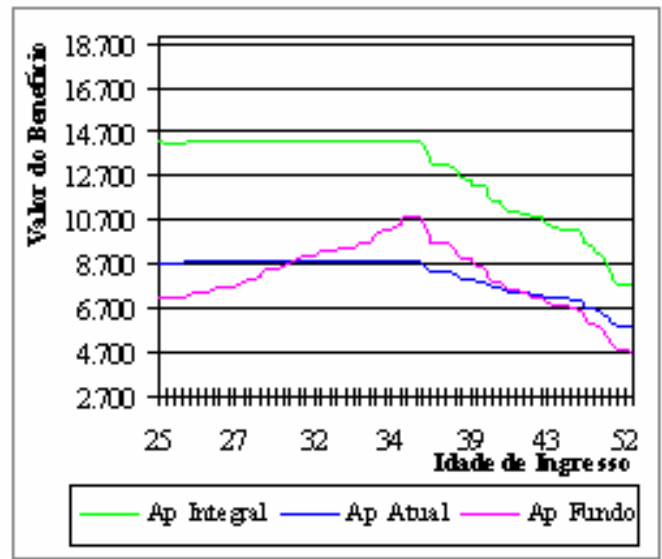

Elaboração própria

\section{Gráfico 6 - Remuneração R\$ 10832}

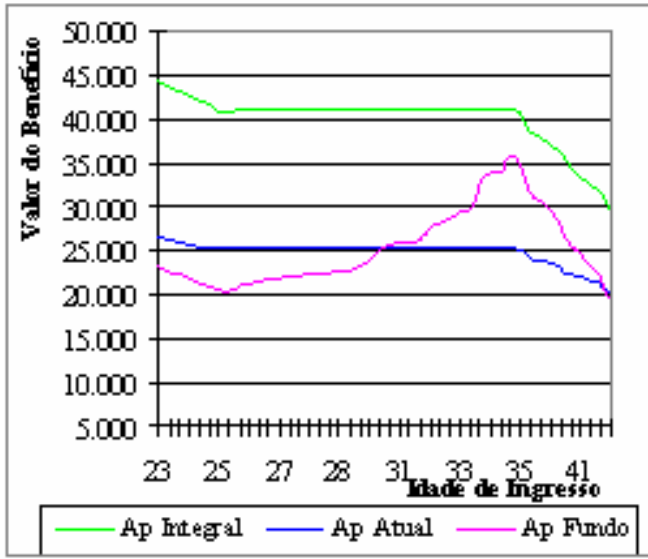

Elaboração própria

\section{Gráfico 7 - Remuneração R\$ 21000}

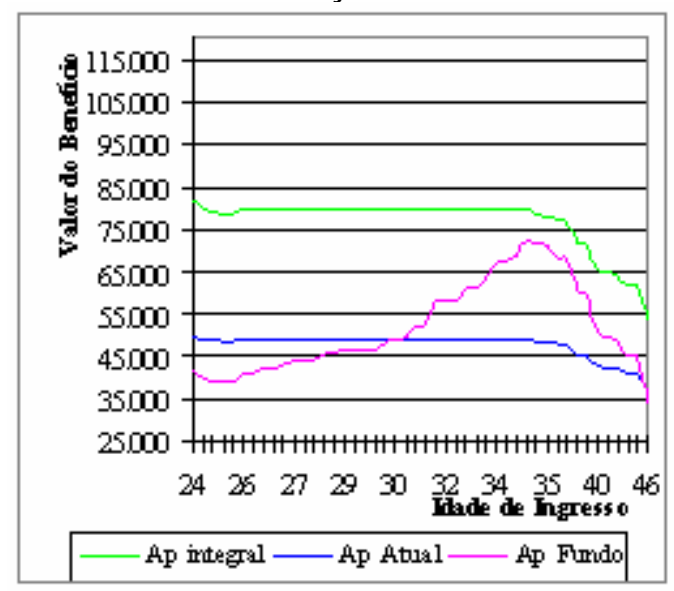

Elaboração própria

A observação desses gráficos revela que, em termos mais gerais, que a aposentadoria dependente da idade que os servidores ingressam no serviço público federal. Esse último efeito ocorre devido ao sistema de capitalização do Fundo que provoca um comportamento típico, observado em todos os gráficos, para os valores dos benefícios de acordo com a idade de ingresso do servidor público.

A novidade desses gráficos em relação aos anteriores, com taxas de juro de $6 \%$ ao ano, é que quando comparamos os valores dos benefícios decorrentes do sistema atual de previdência "Ap Atual" com os valores dos benefícios decorrentes do Fundo "Ap 
Fundo" não temos uma relação de dominância destes em relação àqueles. Essa relação depende da idade do servidor no momento de ingresso no serviço publico. Servidores mais jovens ou mais idosos, no momento de ingresso, receberão maiores benefícios se optarem por permanecer no sistema atual “Ap Atual”. Novamente esse efeito decorre do domínio dos anos de contribuição sobre a sobrevida para o sistema de capitalização. Servidores novos apresentam alta sobrevida e o mesmo tempo de contribuição de servidores com meia idade o que implica em benefícios menores para os primeiros. Já os servidores mais idosos apresentam baixa sobrevida, mas também, menos tempo de contribuição acarretando reduzidos benefícios quando capitalizados.

Resumindo as informações dos gráficos chegamos a duas conclusões. A primeira delas, já verificada nos gráficos anteriores, é que os servidores ingressantes antes do ano de 2003, que receberão aposentadoria integral, não devem migrar para o Fundo. A segunda, diferindo das conclusões apresentadas nos gráficos anteriores, é que ingressantes no serviço publico federal após o ano de 2003 e antes da criação do Fundo podem migrar para o Fundo, mas isso depende da idade de ingresso deles. Fica claro que a redução da expectativa da taxa real de juros de $6 \%$ para $4,5 \%$ ao ano muda os valores dos benefícios pagos pelo Fundo e conseqüentemente afeta a decisão dos servidores quanto a sua participação no Fundo.

O cenário conservador, com taxas de juro real de $3 \%$ ao ano e remunerações de $R \$$ 3764, R\$ 10832 e R\$ 21000 é representado, respectivamente, pelos gráficos 8, 9 e 10.

Gráfico 8 - Remuneração R\$ 3764

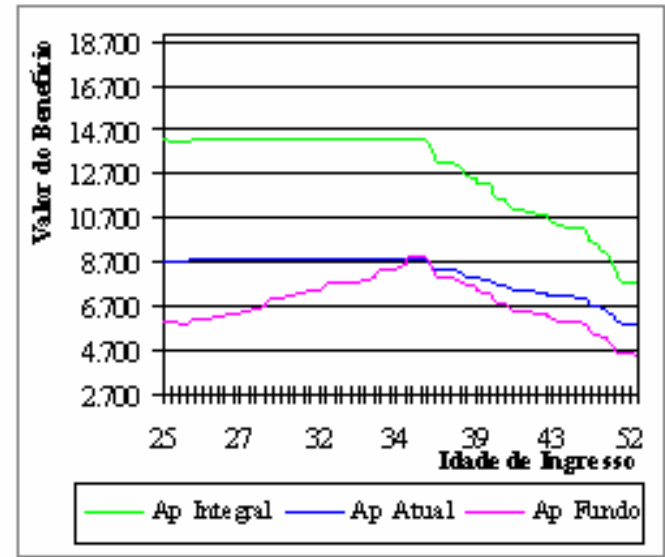

Elaboração própria

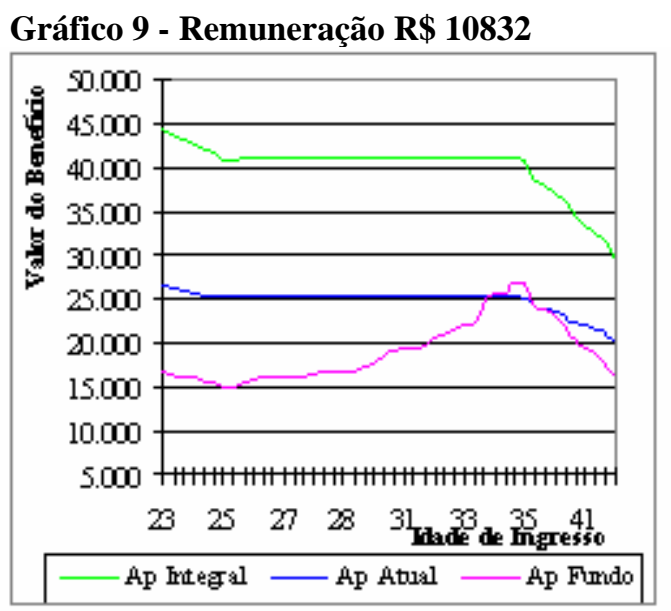

Elaboração própria 
Gráfico 10 - Remuneração R\$ 21000

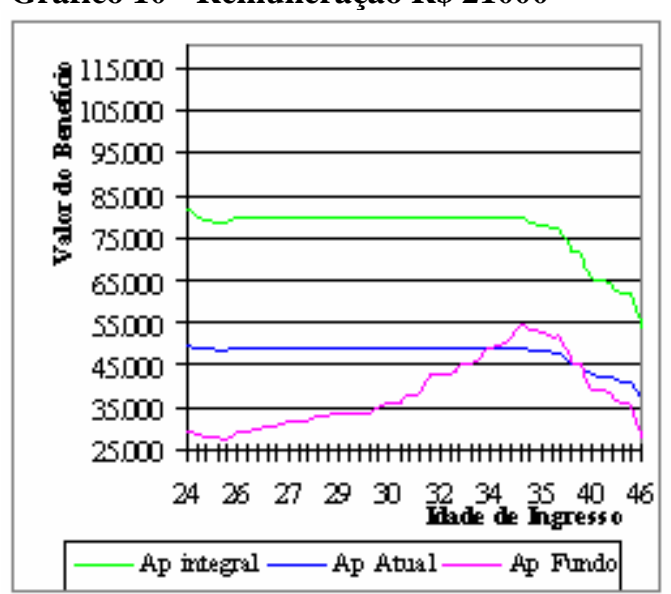

Elaboração própria

A leitura desses gráficos mostra, novamente, valores maiores dos benefícios de aposentadoria decorrentes da aposentadoria integral, "Ap Integral" relativamente aos valores dos benefícios decorrentes da aposentadoria atual, “Ap Atual”, e aposentadoria do Fundo, “Ap Fundo".

A novidade desses gráficos em relação aos anteriores, com taxas de juros de $6 \%$ e $4,5 \%$ ao ano, é que quando comparamos os benefícios decorrentes do sistema atual de previdência com os valores dos benefícios do Fundo previdenciário aqueles superam estes para praticamente todas as idades de ingresso no serviço público federal.

A partir dos gráficos acima chegamos a duas conclusões. A primeira delas, já verificada nos gráficos anteriores, é que os servidores ingressantes antes do ano de 2003, receberão aposentadoria integral, não devem migrar para o Fundo. A segunda é que os ingressantes no serviço público federal após o ano de 2003 e antes da criação do Fundo não devem migrar para o Fundo, diferentemente das conclusões apresentadas nos gráficos anteriores. Fica claro que a redução da expectativa da taxa real de juros de $4,5 \%$ para $3 \%$ ao ano muda os valores dos benefícios pagos pelo Fundo e conseqüentemente afeta a decisão dos servidores quanto a sua participação no Fundo, ou seja, com essa expectativa de taxa de juros os servidores atuais não migrarão para o Fundo. 
O cenário mais conservador possível - uma espécie de limite inferior para a taxa de juros, taxa de juros real de 2,5 \% ao ano - e com remunerações de R\$3764, R\$ 10832 e R\$ 21000 é representado, respectivamente, pelos gráficos 11, 12 e 13.

A leitura desses gráficos mostra, novamente, maiores benefícios de aposentadoria decorrentes da aposentadoria integral, "Ap Integral” relativamente aos valores dos benefícios decorrentes da aposentadoria atual, "Ap Atual”, e aposentadoria do Fundo, "Ap Fundo".

\section{Gráfico 11 - Remuneração R\$ 3764}

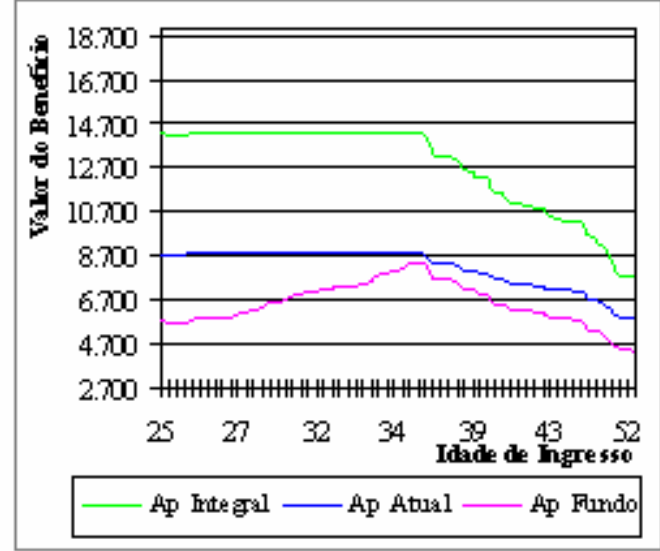

Elaboração própria
Gráfico 12 - Remuneração R\$ 10832

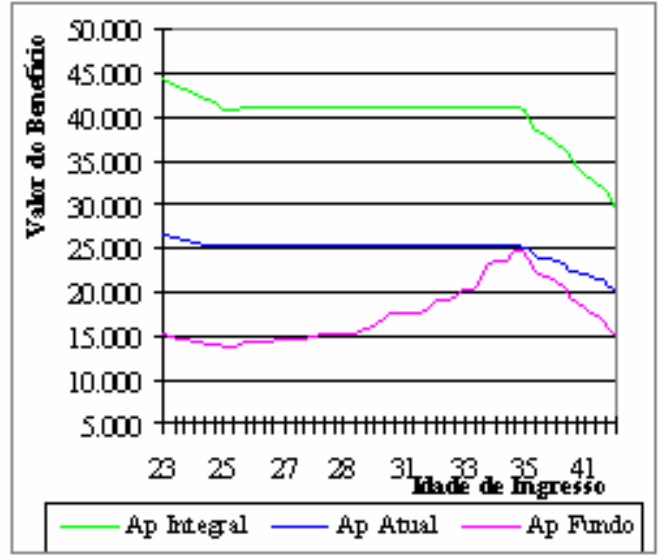

Elaboração própria

\section{Gráfico 13 - Remuneração R\$ 21000}

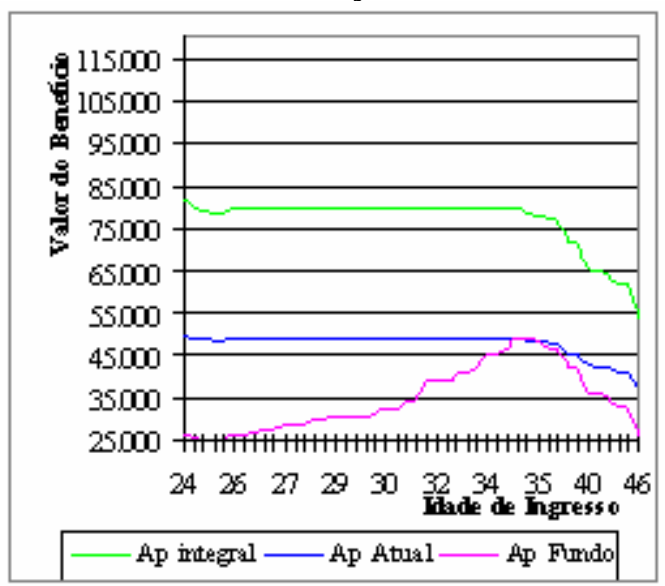

Elaboração própria

Nesses gráficos os benefícios dos servidores do sistema atual de previdência, “Ap Atual", são sempre maiores que os benefícios dos servidores do Fundo, "Ap Fundo" corroborando os resultados dos gráficos anteriores com taxa de juros real de $3 \%$ ao ano. 


\subsection{Valores dos benéficos para servidoras de acordo com os cenários adotados (mulheres)}

Os gráficos abaixo foram simulados para quatro taxas de juros diferentes, mantendo as demais variáveis constantes. Em primeiro lugar fizemos uma simulação para um cenário otimista com taxa de juros reais de 6\% ao ano e remunerações de $\mathrm{R} \$ 3764$, R $\$ 10832$ e R\$ 21000 que são respectivamente os gráficos 14, 15 e 16 .

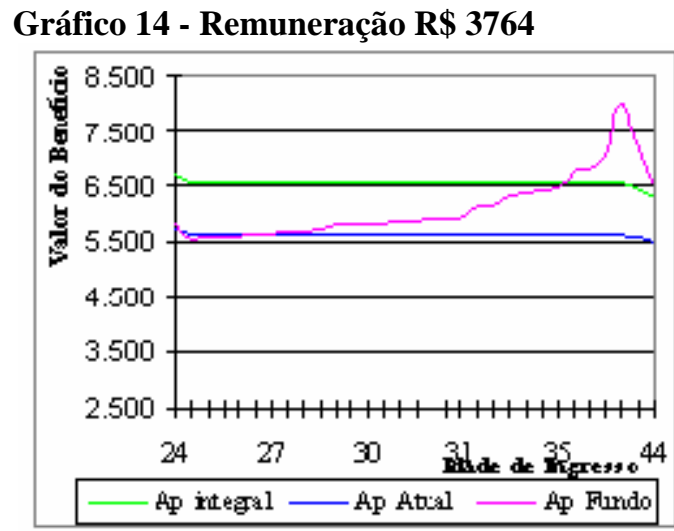

Elaboração própria

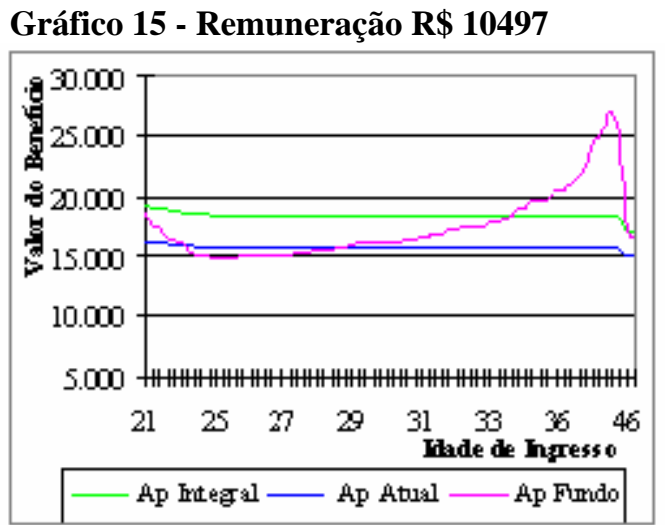

Elaboração própria

\section{Gráfico 16 - Remuneração R 21000}

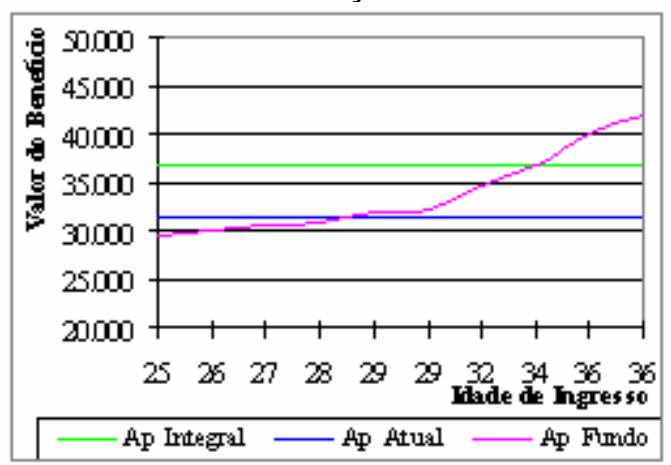

Elaboração própria

A observação desses gráficos revela que a aposentadoria integral "Ap Integral” traz maiores benefícios para as servidoras e isso independente da idade de ingresso no serviço público federal, com exceção das servidoras com idade próxima aos 39 anos. Esse último efeito ocorre devido ao sistema de capitalização do Fundo que provoca um comportamento típico, observado em todos os gráficos, para os valores dos benefícios de acordo com a idade de ingresso da servidora no serviço público.

Para as servidoras que ingressam com idade de 18 até os 25 anos há decréscimo nos valores dos benefícios, basta observar a linha "Ap Fundo" nos gráficos. Nesse caso 
reduz-se o tempo de contribuição da servidora e ao mesmo tempo sua sobrevida, ou seja, o tempo de recebimento de benefícios. Mas como o tempo de contribuição domina a sobrevida, em termos financeiros, temos o decréscimo dos benefícios.

Já para as servidoras que ingressaram com idade entre 25 e 40 anos temos um acréscimo nos valores dos benefícios à medida que a idade de ingresso aumenta. $\mathrm{O}$ aumento dos valores dos benefícios ocorre porque o tempo de contribuição permanece constante e a sobrevida reduz com o aumento da idade de ingresso: a servidora que ingressa com 25 anos aposenta com 55 anos, idade mínima; e o servidora que ingressa com 40 anos de idade aposenta com 70 anos, idade máxima; mas nos dois casos há contribuição de 30 anos. Uma redução da sobrevida mantida constante os valores de contribuição aumenta o valor dos benefícios como descrito nos gráficos acima.

Finalmente, para as servidoras que ingressaram após os 40 anos de idade há decréscimos dos valores dos benefícios à medida que a idade de ingresso aumenta. Esse efeito é provocado pela redução do tempo de contribuição e redução da sobrevida. Como o valor financeiro do tempo de contribuição é sempre dominante sobre o valor financeiro da sobrevida temos a redução do valor do benefício.

Quando comparamos o valor dos benefícios das servidoras que ingressarem após o ano de 2003 e antes da criação do Fundo "Ap Atual” com o valor dos benefícios das servidoras que porventura migrarão para o Fundo "Ap Fundo" observamos os benefícios destas superando os benefícios daquelas apenas para servidoras que ingressariam no Fundo com mais de 30 anos de idade.

Em resumo, a partir da leitura dos gráficos e considerando uma taxa de juros real de $6 \%$ ao ano chegamos a dois resultados distintos: a primeira é que servidoras que recebem aposentadoria integral, ingressantes antes de 2003, na sua maioria, não devem migrar para o Fundo; e a segunda é que servidoras que recebem aposentadoria atual e tenham mais de 30 anos no momento do ingresso na administração publica federal devem migrar para o Fundo.

O cenário intermediário, taxa de juros real de 4,5\% ao ano, e remunerações de R $\$ 3764$, R\$ 10832 e R\$ 21000 é representado, respectivamente, pelos gráficos 17, 18 e 19. 
Os gráficos mostram claramente que, com poucas exceções, os benefícios decorrentes da aposentadoria integral, “Ap Integral”, é superior aos benefícios das servidoras que recebem benefícios do Fundo "Ap Fundo" e das servidoras que recebem benefícios do sistema atual "Ap Atual”.

\section{Gráfico 17 - Remuneração R\$ 3764}

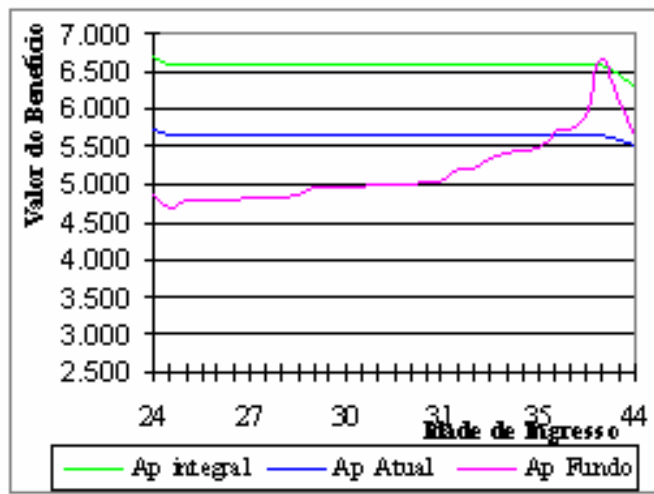

Elaboração própria

\section{Gráfico 19 - Remuneração R 21000}

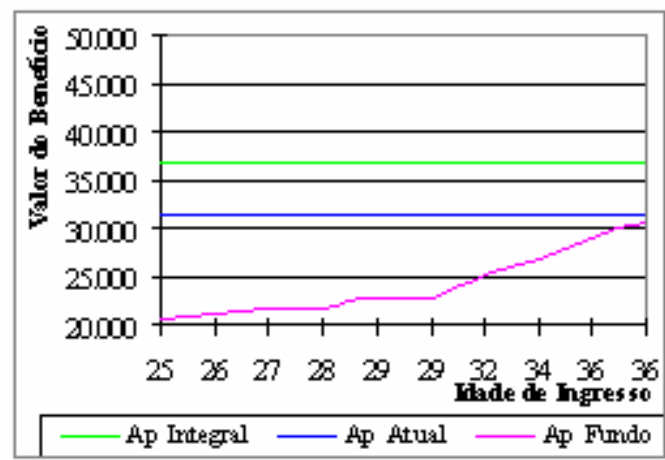

Elaboração própria

\section{Gráfico 18 - Remuneração R 10497}

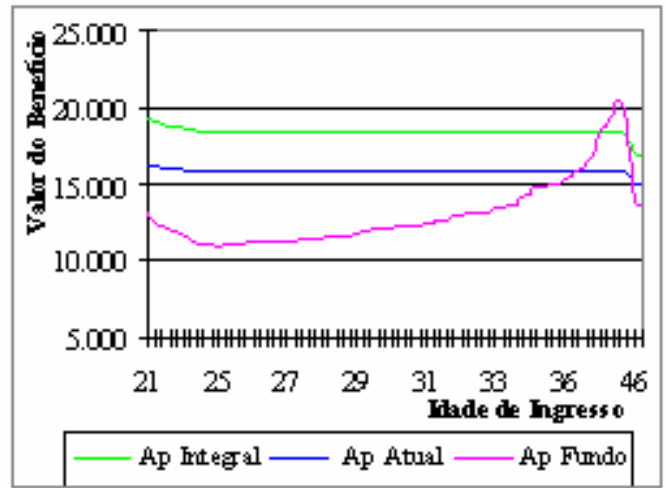

Elaboração própria

Resumindo as informações dos gráficos chegamos a duas conclusões. A primeira delas, já verificada nos gráficos anteriores, é que as servidoras ingressantes antes do ano de 2003 não devem migrar para o Fundo. A segunda, que difere das conclusões apresentadas nos gráficos anteriores, é que ingressantes no serviço publico federal após o ano de 2003 e antes da criação do Fundo não devem migrar para o Fundo, esse resultado vale para a maioria dos ingressantes. Fica claro que a redução da expectativa da taxa real de juros de $6 \%$ para $4,5 \%$ ao ano muda os valores dos benefícios pagos pelo Fundo e conseqüentemente afeta a decisão das servidoras quanto a sua participação no Fundo. 
O cenário conservador, taxas de juro real de 3\% ao ano, e remunerações de $\mathrm{R} \$ 3764, \mathrm{R} \$$ 10832 e R\$ 21000 é representado, respectivamente, pelos gráficos 20, 21 e 22.

A leitura desses gráficos mostra, novamente, valores maiores dos benefícios de aposentadoria decorrentes da aposentadoria integral, "Ap Integral" relativamente aos valores dos benefícios decorrentes da aposentadoria atual, "Ap Atual”, e aposentadoria do Fundo, “Ap Fundo".

\section{Gráfico 20 - Remuneração R\$ 3764}

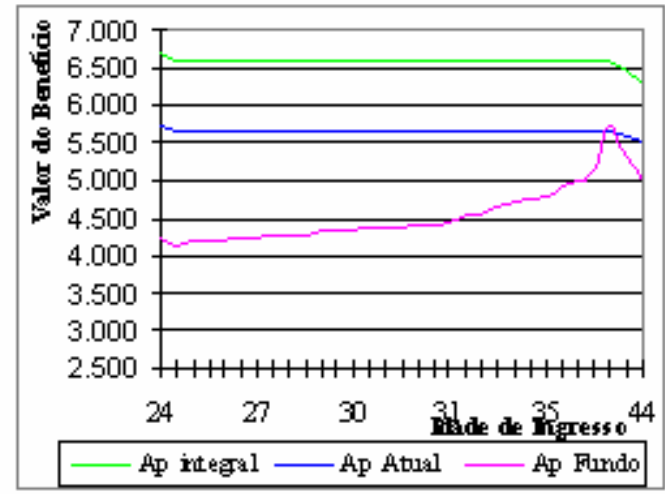

Elaboração própria

\section{Gráfico 21 - Remuneração R\$ 10497}

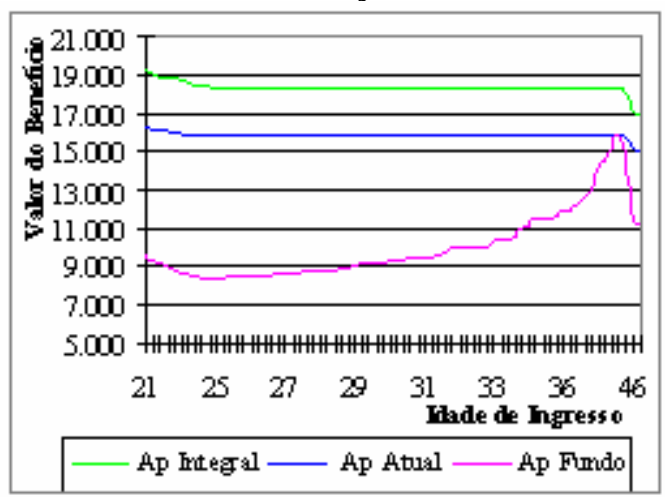

Elaboração própria

\section{Gráfico 22 - Remuneração R\$ 21000}

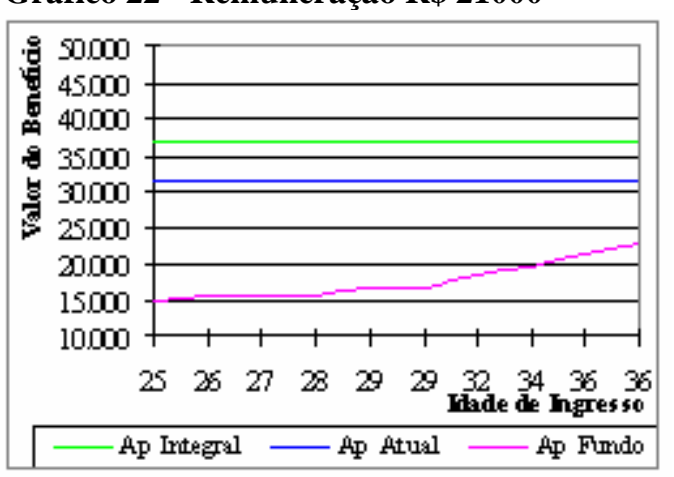

Elaboração própria

A novidade desses gráficos em relação aos anteriores, com taxas de juros de $6 \%$ e $4,5 \%$ ao ano, é que quando comparamos os benefícios decorrentes do sistema atual de previdência com os valores dos benefícios do Fundo previdenciário aqueles superam estes para todas as idades de ingresso no serviço público federal. Ademais apresenta grandes diferenças nos valores dos benefícios pagos por cada sistema. Isso difere muito dos resultados apresentados para os servidores (homens), pois, embora, possuem as mesmas diferenças entre valores dos benefícios estes não eram tão discrepantes como no caso das servidoras. 
A partir dos gráficos acima chegamos a duas conclusões. A primeira delas, já verificada nos gráficos anteriores, é que as servidoras ingressantes antes do ano de 2003 não devem migrar para o Fundo. A segunda, que confirma parte das conclusões apresentadas nos gráficos anteriores, é que as ingressantes no serviço público federal após o ano de 2003 e antes da criação do Fundo não devem migrar para o Fundo. Fica claro que a redução da expectativa da taxa real de juros de $4,5 \%$ para $3 \%$ ao ano muda os valores dos benefícios pagos pelo Fundo e conseqüentemente afeta a decisão das servidoras quanto a sua participação no Fundo, ou seja, com essa expectativa de taxa de juros as servidoras atuais não migrarão para o Fundo.

O cenário mais conservador possível - uma espécie de limite inferior para a taxa de juros, taxa de juros real de 2,5 \% ao ano - e com remunerações de R\$3764, R\$ 10832 e R\$ 21000 é representado, respectivamente, pelos gráficos 23, 24 e 25.

Gráfico 23 - Remuneração R\$ 3764

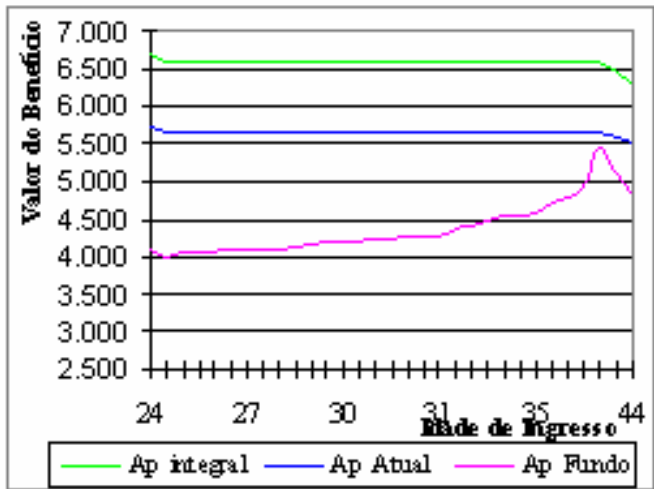

Elaboração própria

\section{Gráfico 24 - Remuneração R\$ 10497}

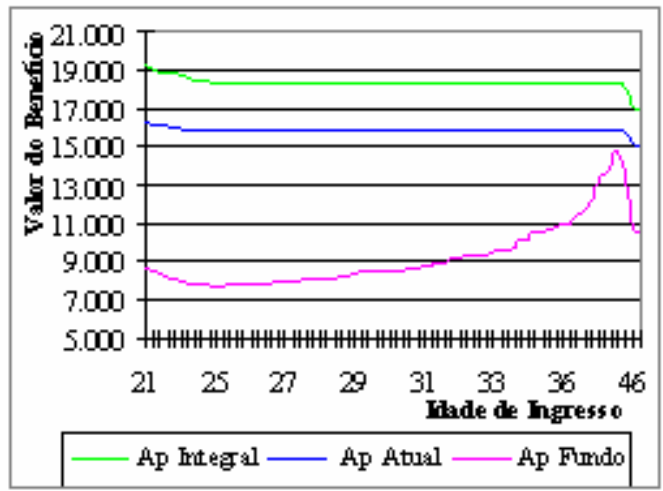

Elaboração própria

Gráfico 25 - Remuneração R\$ 21000

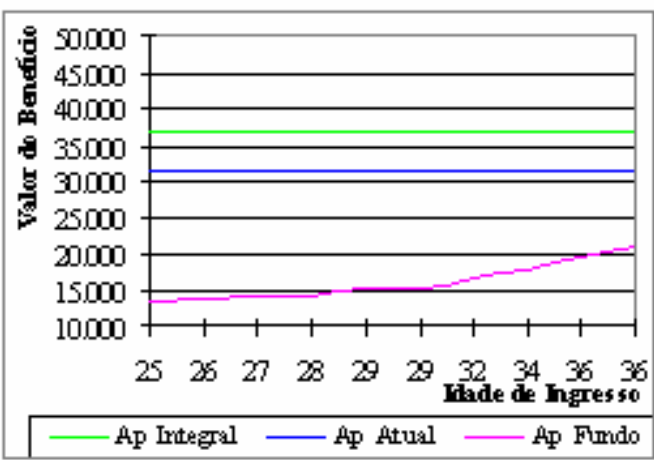

Elaboração própria

A leitura desses gráficos mostra, novamente, maiores benefícios decorrentes da aposentadoria integral, "Ap Integral" relativamente aos valores dos benefícios decorrentes da aposentadoria atual, "Ap Atual”, e aposentadoria do Fundo, “Ap Fundo". 
Nesses gráficos os benefícios das servidoras do sistema atual de previdência, "Ap Atual", são sempre maiores que os benefícios das servidoras do Fundo, "Ap Fundo" corroborando os resultados dos gráficos anteriores com taxa de juros real de $3 \%$ ao ano. E ademais, esses gráficos confirmam as grandes diferenças entre os valores dos benefícios de cada sistema para taxas de juros reais baixas.

Novamente, a partir desses gráficos, concluímos, como no cenário conservador com taxa de juros real de $3 \%$ ao ano, que as servidoras, com aposentadoria integral ou aposentadoria atual, não devem migrar para o Fundo. Fica claro que a redução da expectativa da taxa real de juros de $3 \%$ para $2,5 \%$ reduzindo os valores dos benefícios apenas reforça a conclusão anterior. 


\section{Conclusões}

Nessa dissertação utilizamos uma proxy do modelo Feldstein e Samwick (2001) para analisarmos como será o novo sistema previdenciário federal após a criação do Fundo federal (FUNPRESP). Este modelo sugere a transição de um sistema de repartição para um sistema misto, onde convivem dois sistemas: repartição e capitalização.

Considerando os resultados globais observamos que com a criação do fundo federal os valores dos benefícios pagos pelo fundo e conseqüentemente a migração dos servidores para o fundo passam a depender basicamente da taxa de juros real esperada e da idade do servidor no momento do ingresso no Fundo. Para um cenário otimista com taxas de juros real de $6 \%$ ao ano os resultados são conclusivos para migração para o fundo, independente ao qual plano anterior o servidor pertencia. Mas para esse tipo de análise, para um sistema previdenciário desenhado para vigorar no longo prazo, devemos levar em consideração a taxa de juros de equilíbrio de longo prazo que é uma taxa de juros mais conservadora ${ }^{9}$ do que a de mercado, aproximando do crescimento do PIB. Com uma taxa de juros conservadora, próxima aos 3\%, os resultados não dependem mais da idade de ingresso no Fundo. E os resultados são bastante conclusivos: i) os atuais servidores não deverão migrar para o fundo federal, seus benefícios serão bem menores se migrarem; ii) os servidores que ingressarem no serviço público federal após a criação do fundo e tiverem remuneração acima do piso receberão benefícios menores que os servidores atuais; iii) as mulheres receberão benefícios menores que os homens, em função de menor tempo de contribuição, expectativa de vida maior e menor taxa de crescimento salarial.

Um grande avanço com a criação do fundo será o equilíbrio atuarial do sistema federal de previdência e o fim das grandes desigualdades entre esse sistema e o regime geral de previdência. Pois com a criação do Fundo os benefícios estarão atrelados diretamente à contribuição de cada servidor diferentemente do que ocorria antes quando os benefícios eram proporcionais à remuneração do servidor (até 2003 os benefícios eram

\footnotetext{
9 Argumento utilizado por Oliveira Beltrão e Manieiro (1997), onde é possível ler: "A taxa de desconto adequada para o tipo de exercício que se realiza deve contemplar o 'custo de oportunidade' de aplicação do capital no longo prazo, considerando-se risco nulo e um sistema em escala nacional. Para um esquema como este, as taxas de capitalização devem ser bastante mais conservadoras, pressupondo-se que, no longo prazo, as taxas de remuneração do capital não deverão ser muito diversas das próprias taxas de crescimento do PIB".
} 
equivalentes a última remuneração e depois de 2003 a média das $80 \%$ maiores remunerações). 


\section{Referências Bibliográficas:}

AFONSO, Luís Eduardo; FERNANDES; Fernandes (2003). Uma estimativa dos aspectos distributivos da previdência social no Brasil. Anais do XXXI Encontro Nacional de Economia. Porto Seguro, 9-12 dezembro.

AUEBACH, J. Alan; JAGADEESH, Gokhale; KOTLIKOFF, Laurence J. (1991). Generational accounts: a meaningful alternative to deficit accounting. NBER Working Paper No 3589, National Bureau of Economic Research, Cambridge.

BANCO MUNDIAL, Brazil: Critical Issues in Social Security. Washington, D.C.: Banco Mundial, 2001. p. 244 (A World Bank country study, 22513).

BUGARIN, M. N. S; MAGALHES, Paula Bicudo de Castro (2001). Simulações da previdência social brasileira: estudo de caso do Regime Jurídico Único - RJU. [S.1.]: VI Prêmio do Tesouro Nacional.

FELDSTEIN, Martin (1996). The missing piece in policy analysis: social security reform. NBER Working Paper $N^{0}$ 5413, National Bureau of Economic Research, Cambridge.

FELDSTEIN, Martin; SAMWICK, Andrew. Potential Paths of Social Security Reform, Cambridge: National Bureau of Economic Research, 2001. (Working Paper, 8592)

FERNANDES, Reynaldo; GREMAUD, Amaury Patrick (2003). Regime de previdência dos servidores públicos: equilíbrio financeiro e justiça atuarial. Texto para discussão $N^{\circ}$ 1. ESAF. Ministério da Fazenda.

GIAMBIAGI, Fabio (2002). Proposta para uma agenda de reformas da previdência social. Disponível em: $<$ http://www.ipea.gov.br/TemasEspeciais/FabioGiambiagi.pdf $>$. Acesso em $25 / 06 / 2007$

GIAMBIAGI, Fabio; MENDOÇA, João L. O.; BELTRÃO, Kaizô I.; ARDEO, Vagner L. Diagnóstico da Previdência Social no Brasil: O que foi feito e o que falta 
reformar? Rio de Janeiro: Instituto de Pesquisa Econômica Aplicada, 2004. (Texto para discussão, $\mathrm{N}^{\circ} 1050$ )

GOKHALE, Jagadees; SMETTERS, Kents (2005). Measuring social security's financial problems. NBER Working Paper 11060, National Bureau of Economic Research, Cambridge.

GREMAUD, Amaury Patrick; TONETO, Toneto. (2001). Sistema previdenciário: aspectos teóricos e os problemas brasileiros. P. 315-341. In Dowbor, Ladislau \& Samuel Kilsztajn (orgs). Economia social no Brasil. São Paulo: Editora SENAC, p. 388.

HEMMING, Richard. Should public pension be funded? Oxford: International Social Security Association, 1999. p. 27 (International Social Security Review, Vol. 52, 2/1999)

Holanda, Sílvio F (2000). Impacto intergerações de mudanças em sistemas previdenciários - uma aplicação de generational accounting no Brasil. Disponível em: $<$ www.stn.fazenda.gov.br/Premio_TN/vpremio/financas/1tefpVPTN/HOLANDA. pdf>. Acesso em 25/06/2007.

IYER, Subramaniam. Matemática Atuarial de Sistemas de Previdência Social: Brasília: Ministério da Previdência e Assistência Social, 2002. 182p. (Coleção Previdência Social, Série Traduções; v. 16).

KRITZER, Barbara E. Individual accounts in other countries. ABI/INFORM Global, 2005. (Social Security Bulletin, Vol. 66, 1/2005)

MAgalhães, Paula B. C.; BUGARIN, Mirta N. S. Simulações da Previdência Social Brasileira: estudo de caso do Regime Jurídico Único - RJU. Brasília: Universidade de Brasília, 2001.

MATIJASCIC, Milko; KAY, Stephen J. Social security at the crossroads: Toward effective pension reform in Latin America. Oxford: International Social Security Association, 2006. (International Social Security Review, Vol. 59, 1/2006) 
MONTEIRO, Newton J.; NASCIMENTO, Daniel R. A. Estudo de reavaliação dos componentes atuarias relativos ao sistema de previdência da Universidade de São Paulo. São Paulo: Universidade de São Paulo, 2001.

Oliveira, F. E. B. de, Kaizô Iwakami Beltrão \& Maria Tereza de Marsillac Pasinato (1999). Reforma estrutural da previdência: uma proposta para assegurar proteção social e eqüidade. Rio de Janeiro: IPEA (texto para discussão No 690).

Santos, C.R.N. O papel das pensões no Regime Geral de Previdência Social brasileiro. São Paulo: Universidade de São Paulo, 2006.

Samuelson, Paul. An exact consumption-loan model of interest with or without the social contrivance of money. Journal of Political Economy. LXVI(6), December. pp. 467-82.

SANCHES, Fábio A. M. Balanço Intergeracional: Desequilíbrio Fiscal e Reforma da Previdência no Brasil. 2005. Dissertação (Mestrado em Teoria Econômica) Faculdade de Economia, Administração e Contabilidade, Universidade de São Paulo, 2005.

SOUZA, André P.; ZYLBERSTAJN, Hélio; AFONSO, Luís E.; FLORI, Priscilla M. Fiscal Impacts of Social Security Reform in Brazil. São Paulo: Universidade de São Paulo, 2004.

TURNER, John. Individual Accounts: Lessons from Sweden. United States: Public Policy Institute, AARP, 2004. (International Social Security Review, Vol. 57, $1 / 2004)$

TURNER, John; RAJNES, David M. Rate of return guarantees for mandatory defined contribution plans. Oxford: International Social Security Association, 2001. p.18 (International Social Security Review, Vol. 54, 4/2001)

Yamasaki, Fabio, no prelo. $O$ modelo das contas pessoais de aposentadoria na Universidade de São Paulo. São Paulo: Universidade de São Paulo, 2006.

Vale, Peterson Molina. Efeitos distributivos das alterações recentes na legislação previdenciária, o caso da USP. São Paulo: Universidade de São Paulo, 2006. 
Zylberstajn, Hélio et al. (2004). Fiscal Impacts of social security reform in Brazil.

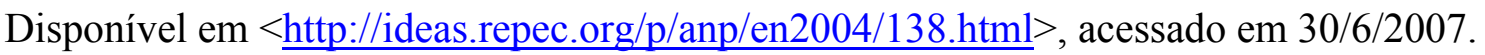




\section{Anexos}

\section{Anexo 1: Resumo das emendas constitucionais}

A Emenda Constitucional No 20 (EC 20) de 1998 tinha como principais medidas:

- Novas exigências para as aposentadorias especiais;

- Mudança na regra de cálculo de benefício, com introdução do fator previdenciário;

- Idade mínima de aposentadoria para servidores públicos que ingressaram antes da reforma fixada em 53 anos para homens e 48 para mulheres

- Idade mínima para novos servidores fixado em 60 anos para os homens e 55 para as mulheres.

Em 2003, foi aprovada a Emenda Constitucional No 40 (EC 40) e em 2005 a EC No 47, que efetivaram as seguintes mudanças:

Para o setor público:

- Servidores contratados antes de 1998 poderiam se aposentar com 53 anos (homens) e 48 (mulheres), entretanto com redução de 5\% no valor do benefício, para cada ano de antecipação;

- Benefício até o teto de $\mathrm{R} \$ 2.400,00$ para os novos servidores públicos;

- Benefício igual ao salário integral para os servidores ingressantes antes de 2003;

- Pensão estaria limitada ao piso previdenciário mais $70 \%$ da diferença entre a remuneração é o valor do piso previdenciário;

- Taxa de contribuição de $11 \%$ do salário;

- Contribuição de $11 \%$ para benefícios acima do piso previdenciário.

Emendas disponíveis em:

http://www.planalto.gov.br/ccivil_03/Constituicao/Emendas/Emc/emc20.htm

http://www.planalto.gov.br/ccivil_03/Constituicao/Emendas/Emc/emc41.htm

http://www.planalto.gov.br/ccivil_03/Constituicao/Emendas/Emc/emc47.htm

\section{Anexo 2: Regras para aposentadoria e pensão dos servidores federais}




\section{Regras constitucionais}

Art. 40. Aos servidores titulares de cargos efetivos da União, dos Estados, do Distrito Federal e dos Municípios, incluídas suas autarquias e fundações, é assegurado regime de previdência de caráter contributivo e solidário, mediante contribuição do respectivo ente público, dos servidores ativos e inativos e dos pensionistas, observados critérios que preservem o equilíbrio financeiro e atuarial e o disposto neste artigo. (Redação dada pela Emenda Constitucional no $41,19.12 .2003$ )

$\S 1^{\circ}$ Os servidores abrangidos pelo regime de previdência de que trata este artigo serão aposentados, calculados os seus proventos a partir dos valores fixados na forma dos $\S \S$ $3^{\circ}$ e 17: (Redação dada pela Emenda Constitucional n $n^{\circ} 41,19.12 .2003$ )

I - por invalidez permanente, sendo os proventos proporcionais ao tempo de contribuição, exceto se decorrente de acidente em serviço, moléstia profissional ou doença grave, contagiosa ou incurável, na forma da lei; (Redação dada pela Emenda Constitucional $\left.\mathrm{n}^{\mathrm{o}} 41,19.12 .2003\right)$

II - compulsoriamente, aos setenta anos de idade, com proventos proporcionais ao tempo de contribuição; (Redação dada pela Emenda Constitucional no 20, de 15/12/98)

III - voluntariamente, desde que cumprido tempo mínimo de dez anos de efetivo exercício no serviço público e cinco anos no cargo efetivo em que se dará a aposentadoria, observadas as seguintes condições: (Redação dada pela Emenda Constitucional $n^{\circ} 20$, de 15/12/98)

a) sessenta anos de idade e trinta e cinco de contribuição, se homem, e cinqüenta e cinco anos de idade e trinta de contribuição, se mulher; (Redação dada pela Emenda Constitucional $n^{\circ} 20$, de 15/12/98)

b) sessenta e cinco anos de idade, se homem, e sessenta anos de idade, se mulher, com proventos proporcionais ao tempo de contribuição. (Redação dada pela Emenda Constitucional $n^{\circ} 20$, de 15/12/98) 
$\S 2^{\circ}$ - Os proventos de aposentadoria e as pensões, por ocasião de sua concessão, não poderão exceder a remuneração do respectivo servidor, no cargo efetivo em que se deu a aposentadoria ou que serviu de referência para a concessão da pensão. (Redação dada pela Emenda Constitucional no 20 , de 15/12/98)

\section{Regra legal (lei 10887/2004)}

Art. $1^{0}$ No cálculo dos proventos de aposentadoria dos servidores titulares de cargo efetivo de qualquer dos Poderes da União, dos Estados, do Distrito Federal e dos Municípios, incluídas suas autarquias e fundações, previsto no $\S 3^{\text {o }}$ do art. 40 da Constituição Federal e no art. $2^{\underline{0}}$ da Emenda Constitucional n ${ }^{\circ} 41$, de 19 de dezembro de 2003, será considerada a média aritmética simples das maiores remunerações, utilizadas como base para as contribuições do servidor aos regimes de previdência a que esteve vinculado, correspondentes a $80 \%$ (oitenta por cento) de todo o período contributivo desde a competência julho de 1994 ou desde a do início da contribuição, se posterior àquela competência.

$\S 1^{\underline{0}}$ As remunerações consideradas no cálculo do valor inicial dos proventos terão os seus valores atualizados mês a mês de acordo com a variação integral do índice fixado para a atualização dos salários-de-contribuição considerados no cálculo dos benefícios do regime geral de previdência social.

$\S 2^{\underline{o}}$ A base de cálculo dos proventos será a remuneração do servidor no cargo efetivo nas competências a partir de julho de 1994 em que não tenha havido contribuição para regime próprio.

$\S 3^{\circ}$ Os valores das remunerações a serem utilizadas no cálculo de que trata este artigo serão comprovados mediante documento fornecido pelos órgãos e entidades gestoras dos regimes de previdência aos quais o servidor esteve vinculado ou por outro documento público, na forma do regulamento.

$\S 4^{0}$ Para os fins deste artigo, as remunerações consideradas no cálculo da aposentadoria, atualizadas na forma do $\S 1^{\circ}$ deste artigo, não poderão ser:

I - inferiores ao valor do salário-mínimo; 
II - superiores ao limite máximo do salário-de-contribuição, quanto aos meses em que o servidor esteve vinculado ao regime geral de previdência social.

$\S 5^{\circ}$ Os proventos, calculados de acordo com o caput deste artigo, por ocasião de sua concessão, não poderão ser inferiores ao valor do salário-mínimo nem exceder a remuneração do respectivo servidor no cargo efetivo em que se deu a aposentadoria.

Art. $2^{\underline{0}}$ Aos dependentes dos servidores titulares de cargo efetivo e dos aposentados de qualquer dos Poderes da União, dos Estados, do Distrito Federal e dos Municípios, incluídas suas autarquias e fundações, falecidos a partir da data de publicação desta Lei, será concedido o benefício de pensão por morte, que será igual:

I - à totalidade dos proventos percebidos pelo aposentado na data anterior à do óbito, até o limite máximo estabelecido para os benefícios do regime geral de previdência social, acrescida de $70 \%$ (setenta por cento) da parcela excedente a este limite; ou

II - à totalidade da remuneração do servidor no cargo efetivo na data anterior à do óbito, até o limite máximo estabelecido para os benefícios do regime geral de previdência social, acrescida de $70 \%$ (setenta por cento) da parcela excedente a este limite, se o falecimento ocorrer quando o servidor ainda estiver em atividade.

Parágrafo único. Aplica-se ao valor das pensões o limite previsto no art. $40, \S 2^{\underline{0}}$, da Constituição Federal.

Art. $3^{0}$ Para os fins do disposto no inciso XI do art. 37 da Constituição Federal, a União, os Estados, o Distrito Federal e os Municípios instituirão sistema integrado de dados relativos às remunerações, proventos e pensões pagos aos respectivos servidores e militares, ativos e inativos, e pensionistas, na forma do regulamento.

Art. $4^{\circ}$ A contribuição social do servidor público ativo de qualquer dos Poderes da União, incluídas suas autarquias e fundações, para a manutenção do respectivo regime próprio de previdência social, será de $11 \%$ (onze por cento), incidente sobre a totalidade da base de contribuição. (Vide Emenda Constitucional no 47, de 2005) 


\section{Anexo 3: Projeto de lei que cria o Fundo Previdenciário Federal (FUNPRESP)}

\section{CAPÍTULO I}

DO REGIME DE PREVIDÊNCIA COMPLEMENTAR

Art. $1^{\circ}$ Fica instituído, nos termos desta Lei, o regime de previdência complementar a que se referem os $\S \S 14,15$ e 16 do art. 40 da Constituição para os servidores públicos titulares de cargo efetivo da União, suas autarquias e fundações, inclusive para os membros do Poder Judiciário, do Ministério Público e do Tribunal de Contas da União.

Parágrafo único. Os atuais servidores e os membros referidos no caput deste artigo que tenham ingressado no serviço público até o dia anterior ao início do funcionamento da entidade a que se refere o art. $4^{\underline{0}}$ desta Lei poderão, mediante prévia e expressa opção, aderir ao regime de que trata este artigo, observado o disposto no art. $3^{\text {o }}$ desta Lei.

Art. $2^{\circ}$ Para os efeitos desta Lei, entende-se por:

I - patrocinador: a União, suas autarquias e fundações, em decorrência da aplicação desta Lei, bem como os Estados, o Distrito Federal, os Municípios, suas autarquias e fundações, que aderirem a plano de benefícios nos termos do art. 23 desta Lei;

II - participante: o servidor público titular de cargo efetivo, inclusive o membro do Poder Judiciário, do Ministério Público e do Tribunal de Contas, dos patrocinadores elencados no inciso I, que aderir ao plano de benefícios administrado pela entidade a que se refere o art. $4^{-}$desta Lei;

III - assistido: o participante ou o seu beneficiário em gozo de benefício de prestação continuada.

Art. $3^{\circ}$ Aplica-se o limite máximo estabelecido para os benefícios do regime geral de previdência social às aposentadorias e pensões a serem concedidas pelo regime de previdência da União de que trata o art. 40 da Constituição, observado o 
disposto na Lei $\mathrm{n}^{\mathrm{o}}$ 10.887, de 18 de junho de 2004 , aos servidores e membros referidos no caput do art. $1^{\circ}$ desta Lei que:

I - ingressarem no serviço público a partir da data do início do funcionamento da entidade a que se refere o art. $4^{\circ}$ desta Lei, independentemente de sua adesão ao plano de benefícios;

II - tenham ingressado no serviço público até o dia anterior à data do início do funcionamento da entidade a que se refere o art. $4^{\circ}$ desta Lei e que exerçam a opção prevista no $§ 16$ do art. 40 da Constituição.

$\S 1^{\underline{o}}$ É assegurado aos servidores e membros referidos no inciso II do caput deste artigo o direito a um benefício especial calculado com base nas contribuições recolhidas ao regime de previdência da União de que trata o art. 40 da Constituição, observada a sistemática estabelecida nos $\S \S 2^{\circ}$ e $3^{\circ}$ deste artigo.

$\S 2^{\circ} \mathrm{O}$ benefício especial será equivalente à diferença entre a média aritmética simples das maiores remunerações anteriores à data da opção, utilizadas como base para as contribuições do servidor ao regime de previdência da União, atualizadas pelo Índice de Preços ao Consumidor Amplo - IPCA, divulgado pela Fundação Instituto Brasileiro de Geografia e Estatística - IBGE, correspondentes a oitenta por cento de todo o período contributivo desde a competência julho de 1994 ou desde a do início da contribuição, se posterior àquela competência, e o limite máximo a que se refere o caput deste artigo, na forma regulamentada pelo Poder Executivo, multiplicada pelo fator de conversão.

$\S 3^{\circ} \mathrm{O}$ fator de conversão de que trata o $\S 2^{\circ}$ deste artigo, cujo resultado é limitado ao máximo de um, será calculado mediante a aplicação da seguinte fórmula:

$$
F C=\frac{T C}{T t}
$$

Onde:

$\mathrm{FC}=$ fator de conversão; 
$\mathrm{Tc}=$ quantidade de contribuições mensais efetuadas para o regime de previdência da União de que trata o art. 40 da Constituição, efetivamente pagas pelo servidor titular de cargo efetivo da União ou por membro do Poder Judiciário, do Poder Legislativo, do Tribunal de Contas e do Ministério Público da União até a data de opção;

$\mathrm{Tt}=455$, quando servidor titular de cargo efetivo da União ou membro do Poder Judiciário, do Poder Legislativo, do Tribunal de Contas e do Ministério Público da União do sexo masculino, ou 390, quando servidor titular de cargo efetivo da União ou membro do Poder Judiciário, do Poder Legislativo, do Tribunal de Contas e do Ministério Público da União do sexo feminino.

$\S 4^{\underline{0}} \mathrm{O}$ benefício especial será pago pelo órgão competente da União quando da concessão de aposentadoria, inclusive por invalidez, ou pensão por morte pelo regime de previdência da União de que trata o art. 40 da Constituição, enquanto perdurar o benefício pago por esse regime.

$\S 5^{0} \mathrm{O}$ benefício especial calculado será atualizado pelo IPCA.

$\S 6^{0}$ O prazo para a opção de que trata o inciso II do caput deste artigo será de cento e oitenta dias, contados a partir da data do início do funcionamento da entidade de que trata o art. $4^{\circ}$ desta Lei.

$\S 7^{0}$ A opção a que se refere o inciso II deste artigo implica renúncia irrevogável e irretratável aos direitos decorrentes das regras previdenciárias anteriores, não sendo devida pela União, suas autarquias e fundações qualquer contrapartida referente ao valor dos descontos já efetuados sobre base de contribuição acima do limite previsto no caput deste artigo.

\section{CAPÍTULO II}

DA ENTIDADE FECHADA DE PREVIDÊNCIA COMPLEMENTAR

\section{Seção I}

\section{Da Criação da Entidade}


Art. 4 ${ }^{\underline{0}}$ Fica a União autorizada a criar, em ato do Poder Executivo, a entidade fechada de previdência complementar denominada Fundação de Previdência Complementar do Servidor Público Federal - FUNPRESP, com a finalidade de administrar e executar plano de benefícios de caráter previdenciário, nos termos das Leis Complementares nos 108 e 109, de 29 de maio de 2001.

Parágrafo único. A FUNPRESP será estruturada na forma de fundação com personalidade jurídica de direito privado, gozará de autonomia administrativa, financeira e gerencial e terá sede e foro no Distrito Federal.

\section{Seção II}

\section{Da Organização da FUNPRESP}

Art. 5 ${ }^{\circ}$ A estrutura organizacional da FUNPRESP será constituída de conselho deliberativo, conselho fiscal e diretoria-executiva, observadas as disposições da Lei Complementar n⿳ำ 108, de 2001.

$\S 1^{\underline{0}}$ Os membros do conselho deliberativo e do conselho fiscal, representantes dos patrocinadores, serão nomeados pelo Presidente da República, observado o seguinte:

I - a Presidência da República, o Congresso Nacional e o Supremo Tribunal Federal indicarão, cada qual, um membro para compor o conselho deliberativo;

II - o Ministério Público da União e o Tribunal de Contas da União indicarão, cada qual, um membro para compor o conselho fiscal.

$\S 2^{\underline{0}}$ A presidência do conselho deliberativo será exercida de forma rotativa pelos membros indicados pelos patrocinadores, na forma prevista no estatuto da FUNPRESP.

$\S 3^{\underline{0}}$ A diretoria-executiva será composta, no máximo, por quatro membros nomeados pelo presidente do conselho deliberativo, por indicação deste colegiado. 
$\S 4^{\underline{0}}$ A remuneração e as vantagens de qualquer natureza dos membros da diretoria-executiva da FUNPRESP serão fixadas pelo seu conselho deliberativo em valores compatíveis com os níveis prevalecentes no mercado de trabalho para profissionais de graus equivalentes de formação profissional e de especialização, observado o disposto no inciso XI do art. 37 da Constituição.

$\S 5^{\circ}$ A remuneração dos membros dos conselhos deliberativo e fiscal é limitada a dez por cento do valor da remuneração dos membros da diretoria-executiva.

$\S 6^{\circ}$ Os requisitos previstos nos incisos I a IV do art. 20 da Lei Complementar $\mathrm{n}^{\mathrm{o}}$ 108, de 2001, estendem-se aos membros dos conselhos deliberativo e fiscal da FUNPRESP.

\section{Seção III}

\section{Das Disposições Gerais}

Art. $6^{\circ}$ Fica exigida a instituição de código de ética e de conduta, inclusive com regras para prevenir conflito de interesse e proibição de operações dos dirigentes com partes relacionadas, que terá ampla divulgação, especialmente entre os participantes e assistidos e as partes relacionadas, cabendo ao conselho fiscal assegurar o seu cumprimento.

Parágrafo único. Compete ao órgão regulador e fiscalizador das entidades fechadas de previdência complementar definir o universo das partes relacionadas a que se refere o caput deste artigo.

Art. $7^{\underline{0}}$ O regime jurídico de pessoal da FUNPRESP será o previsto na legislação trabalhista.

Art. $8^{-}$A natureza pública das entidades fechadas a que se refere o $\S 15$ do art. 40 da Constituição consistirá na:

I - submissão à legislação federal sobre licitação e contratos administrativos;

II - realização de concurso público para a contratação de pessoal; 
III - publicação anual, na imprensa oficial ou em sítio oficial da administração pública certificado digitalmente por autoridade para esse fim credenciada no âmbito da Infra-Estrutura de Chaves Públicas Brasileira - ICP-Brasil, de seus demonstrativos contábeis, atuariais, financeiros e de benefícios, sem prejuízo do fornecimento de informações aos participantes e assistidos do plano de benefícios e ao órgão regulador e fiscalizador das entidades fechadas de previdência complementar, na forma das Leis Complementares $\mathrm{n}^{\mathrm{os}} 108$ e 109, de 2001.

Art. $9^{0}$ A administração da FUNPRESP observará os princípios da eficiência e da economicidade, devendo adotar mecanismos de gestão operacional que maximizem a utilização de recursos de forma a otimizar o atendimento aos participantes e assistidos e diminuir as despesas administrativas.

$\S 1^{\underline{0}}$ As despesas administrativas referidas no caput deste artigo serão custeadas na forma do regulamento do plano de benefícios, observado o disposto no caput do art. $7^{\circ}$ da Lei Complementar $\mathrm{n}^{-0} 108$, de 2001, e ficarão limitadas aos valores estritamente necessários à sustentabilidade do funcionamento da FUNPRESP.

$\S 2^{0} \mathrm{O}$ montante de recursos destinados à cobertura das despesas administrativas será revisado ao final de cada ano, com vistas ao atendimento do disposto neste artigo.

Art. 10. A FUNPRESP será mantida integralmente por suas receitas, oriundas das contribuições dos participantes, assistidos e patrocinadores, dos resultados financeiros de suas aplicações e de doações e legados de qualquer natureza, observado o disposto no $\S 3^{\circ}$ do art. 202 da Constituição.

Art. 11. A União, suas autarquias e fundações, são responsáveis, na qualidade de patrocinadores, pelo pagamento de contribuições e pela transferência à FUNPRESP das contribuições descontadas dos seus servidores, observado o disposto nesta Lei e no estatuto da entidade.

Parágrafo único. As contribuições devidas pelos patrocinadores deverão ser pagas de forma centralizada pelos respectivos Poderes da União e pelo Ministério Público da União. 


\section{CAPÍTULO III \\ DOS PLANOS DE BENEFÍCIOS}

\section{Seção I}

Das Linhas Gerais dos Planos de Benefícios

Art. 12. Os planos de benefícios da FUNPRESP serão estruturados na modalidade de contribuição definida, nos termos da regulamentação estabelecida pelo órgão regulador e fiscalizador das entidades fechadas de previdência complementar, e financiados de acordo com os planos de custeio definidos nos termos do art. 18 da Lei Complementar $\mathrm{n}^{\mathrm{0}}$ 109, de 2001, observadas as demais disposições da Lei Complementar $\mathrm{n}^{\mathrm{o}} 108$, de 2001 .

$\S 1^{\underline{0}}$ A distribuição das contribuições nos planos de benefícios e nos planos de custeio será revista sempre que necessário, para manter o equilíbrio permanente dos planos de benefícios.

$\S 2^{\underline{0}}$ Sem prejuízo do disposto no $\S 3^{\circ}$ do art. 18 da Lei Complementar $\mathrm{n}^{\mathrm{o}} 109$, de 2001, o valor do benefício programado será calculado de acordo com o montante do saldo da conta acumulado pelo participante, devendo o valor do benefício estar permanentemente ajustado ao referido saldo.

$\S 3^{0}$ Os benefícios não-programados serão definidos no regulamento do respectivo plano, devendo ser assegurados, pelo menos, os benefícios decorrentes dos eventos invalidez e morte.

Art. 13. Os requisitos para aquisição, manutenção e perda da qualidade de participante, assim como os requisitos de elegibilidade, forma de concessão, cálculo e pagamento dos benefícios deverão constar do regulamento do plano de benefícios, observadas as disposições das Leis Complementares $\mathrm{n}^{\text {os }} 108$ e 109, de 2001, e a regulamentação do órgão regulador e fiscalizador das entidades fechadas de previdência complementar.

\section{Seção II}

\section{Da Manutenção da Filiação}


Art. 14. Poderá permanecer filiado ao respectivo plano de benefícios o participante:

I - cedido a outro órgão ou entidade da administração pública direta ou indireta da União, Estados, Distrito Federal e Municípios, inclusive suas empresas públicas e sociedades de economia mista;

II - afastado ou licenciado do cargo efetivo temporariamente, com ou sem recebimento de remuneração;

III - que optar pelo benefício proporcional diferido ou autopatrocínio, na forma do regulamento do plano de benefícios.

$\S 1^{\circ}$ O regulamento do plano de benefícios disciplinará as regras para a manutenção do custeio do plano de benefícios, observada a legislação aplicável.

$\S 2^{\underline{0}} \mathrm{O}$ patrocinador arcará com a sua contribuição somente quando a cessão, o afastamento ou a licença do cargo efetivo implicar ônus para a União, suas autarquias e fundações.

\section{Seção III}

\section{Dos Recursos Garantidores}

Art. 15. A administração dos recursos garantidores, provisões e fundos dos planos de benefícios, resultantes das receitas previstas no art. 10 desta Lei deverá ser realizada mediante a contratação de instituições autorizadas pela Comissão de Valores Mobiliários - CVM para o exercício da administração de carteira de valores mobiliários, observado o disposto no art. 10 e nos incisos I, III e IV do art. 13 da Lei Complementar $\mathrm{n}^{\mathrm{o}}$ 108, de 2001.

$\S 1^{\text {o }}$ A aplicação dos recursos previstos no caput deste artigo será feita exclusivamente por meio de fundos de investimento atrelados a índices de referência de mercado, observadas as diretrizes e limites prudenciais estabelecidos pelo Conselho Monetário Nacional para as entidades fechadas de previdência complementar.

$\S 2^{\underline{o}}$ Os fundos de investimento a que se refere o $\S 1^{\circ} \underline{\text { deste }}$ artigo deverão ser criados especificamente para remunerar os recursos garantidores, as provisões e os fundos do plano de benefícios e ser devidamente registrados na CVM. 
$\S 3^{0}$ A contratação das instituições a que se refere o caput será feita mediante licitação, cujos contratos terão prazo total máximo de execução de cinco anos.

$\S 4^{\circ} \mathrm{O}$ edital da licitação prevista no $\S 3^{\mathrm{o}}$ estabelecerá, entre outras, disposições relativas aos limites de taxa de administração e de custos que poderão ser imputados aos fundos, bem como, no que concerne aos administradores, a solidez, o porte e a experiência em gestão de recursos.

$\S 5^{\circ}$ Cada instituição contratada na forma do caput poderá administrar, no máximo, quarenta por cento dos recursos garantidores, provisões e fundos dos planos de benefícios da FUNPRESP.

\section{Seção IV}

\section{Da Base de Cálculo}

Art. 16. As contribuições do patrocinador e do participante incidirão sobre a parcela da remuneração que exceder o limite máximo a que se refere o art. $3^{\underline{0}}$ desta Lei, observado o disposto no inciso XI do art. 37 da Constituição.

$\S 1^{\text {o }}$ Para efeitos desta Lei, considera-se remuneração:

I - o valor do subsídio do participante;

II - o valor do vencimento do cargo efetivo ocupado pelo participante, acrescido das vantagens pecuniárias permanentes estabelecidas em lei, dos adicionais de caráter individual ou quaisquer outras vantagens, e, mediante opção expressa do servidor, das parcelas remuneratórias percebidas em decorrência de local de trabalho e do exercício de cargo em comissão ou função de confiança, excluídas:

a) as diárias para viagens;

b) a ajuda de custo em razão de mudança de sede;

c) a indenização de transporte;

d) o salário-família;

e) o auxílio-alimentação; 
f) o auxílio-creche;

g) as parcelas indenizatórias pagas em decorrência de local de trabalho;

h) o abono de permanência de que tratam o $\S 19$ do art. 40 da Constituição, o $\S 5^{\circ}$ do art. $2^{\circ}$ e o $\S 1^{\circ}$ do art. $3^{\circ}$ da Emenda Constitucional $n^{\circ} 41$, de 19 de dezembro de 2003.

$\S 2^{\circ}$ A alíquota da contribuição do participante será por ele definida, observado o disposto no regulamento do plano de benefícios.

$\S 3^{0}$ A alíquota da contribuição do patrocinador será igual à do participante, observado o disposto no regulamento do plano de benefícios, e não poderá exceder o percentual de sete e meio por cento.

\section{Seção V}

\section{Das Disposições Especiais}

Art. 17. O plano de custeio previsto no art. 18 da Lei Complementar $\mathrm{n}^{\mathrm{o}}$ 109, de 2001, discriminará o percentual da contribuição do participante e do patrocinador, conforme o caso, para cada um dos benefícios previstos no plano de benefícios, observado o disposto no art. $6^{\circ}$ da Lei Complementar $n^{0}$ 108, de 2001.

Art. 18. A FUNPRESP manterá controle das reservas constituídas em nome do participante, registrando contabilmente as contribuições deste e as do patrocinador.

Art. 19. Durante a fase de percepção de renda programada e atendidos os requisitos estabelecidos no plano de benefícios, o assistido poderá transferir as reservas constituídas em seu nome para entidade de previdência complementar ou companhia seguradora autorizada a operar planos de previdência complementar, com o objetivo específico de contratar plano de renda vitalícia, observado o disposto no $\S 2^{\underline{o}}$ do art. 33 da Lei Complementar $n^{\mathrm{o}}$ 109, de 2001.

\section{CAPÍTULO IV}

DO CONTROLE E DA FISCALIZAÇÃO 
Art. 20. A constituição, o funcionamento e a extinção da FUNPRESP, a aplicação de seu estatuto, regulamentos dos planos de benefícios, convênios de adesão e suas respectivas alterações, assim como as retiradas de patrocínio, dependerão de prévia e expressa autorização do órgão regulador e fiscalizador das entidades fechadas de previdência complementar.

Parágrafo único. Serão submetidas ao órgão regulador e fiscalizador das entidades fechadas de previdência complementar, acompanhadas de manifestação favorável do Ministério do Planejamento, Orçamento e Gestão:

I - as propostas de aprovação do estatuto e de instituição de plano de benefícios da FUNPRESP, bem como suas alterações;

II - a proposta de adesão de novos patrocinadores a planos de benefícios em operação na FUNPRESP.

Art. 21. A supervisão e físcalização da FUNPRESP e dos seus planos de benefícios compete ao órgão regulador e fiscalizador das entidades fechadas de previdência complementar.

$\S 1^{\underline{0}}$ A competência exercida pelo órgão referido no caput deste artigo não exime os patrocinadores da responsabilidade pela supervisão e fiscalização sistemática das atividades da FUNPRESP.

$\S 2^{0}$ Os resultados da supervisão e fiscalização exercidas pelos patrocinadores serão encaminhados ao órgão mencionado no caput deste artigo.

Art. 22. Aplica-se no âmbito da FUNPRESP o regime disciplinar previsto no Capítulo VII da Lei Complementar n⿳ํㅜ 109, de 2001.

\section{CAPÍTULO V}

\section{DAS DISPOSIÇÕES FINAIS E TRANSITÓRIAS}

Art. 23. É facultada aos Estados, Distrito Federal e Municípios, suas respectivas autarquias e fundações públicas, a adesão, na qualidade de patrocinadores, a planos de benefícios específicos da FUNPRESP que mantenham as mesmas características do plano de benefícios dos servidores da União, nos termos do estatuto 
da entidade, observado o disposto no art. 13 da Lei Complementar $n^{\mathrm{o}}$ 109, de 2001, desde que prestadas as garantias suficientes ao pagamento das contribuições.

Parágrafo único. A adesão prevista no caput deste artigo abrangerá necessariamente todos os servidores públicos titulares de cargo efetivo do ente federativo e de suas autarquias e fundações públicas, inclusive os membros do Poder Judiciário, do Ministério Público e do Tribunal de Contas.

Art. 24. Após a autorização de funcionamento da FUNPRESP, nos termos desta Lei, o Presidente da República nomeará os servidores que deverão compor provisoriamente o conselho deliberativo e o conselho fiscal da entidade, observado o seguinte:

I - o Ministro de Estado do Planejamento, Orçamento e Gestão e o Presidente do Supremo Tribunal Federal indicarão, cada um, dois membros, e os Presidentes do Senado Federal e da Câmara dos Deputados indicarão, cada um, um membro para compor o Conselho Deliberativo;

II - o Procurador-Geral da República e o Presidente do Tribunal de Contas da União indicarão, cada um, dois membros para compor o conselho fiscal.

Parágrafo único. O mandato dos conselheiros de que trata o caput deste artigo será de dois anos, durante os quais será realizada eleição direta para que os participantes e assistidos elejam os seus representantes e os patrocinadores indiquem os seus representantes, nos termos da Lei Complementar nº 108, de 2001.

Art. 25. Para fins de implantação, fica a FUNPRESP equiparada às pessoas jurídicas a que se refere o art. $1^{\underline{o}}$ da Lei $\mathrm{n}^{\mathrm{o}} 8.745$, de 9 de dezembro de 1993, com vistas à contratação de pessoal técnico e administrativo por tempo determinado.

$\S 1^{0}$ Considera-se como necessidade temporária de excepcional interesse público, para os efeitos da Lei $\mathrm{n}^{\mathrm{o}}$ 8.745, de 1993, a contratação de pessoal técnico e administrativo, por tempo determinado, imprescindível ao funcionamento inicial da FUNPRESP. 
$\S 2^{\underline{o}}$ As contratações observarão o disposto nos arts. $3^{\underline{0}}$, caput, $6^{\underline{0}}, 7^{\underline{0}}$, inciso II, $9^{\circ}$ e 12 da Lei $n^{0} 8.745$, de 1993, e não poderão exceder o prazo de vinte e quatro meses.

Art. 26. Fica a União autorizada, em caráter excepcional, no ato de criação da FUNPRESP, a promover aporte no valor de até R\$ 50.000.000,00 (cinqüenta milhões de reais) a título de adiantamento de contribuições futuras, necessário ao regular funcionamento inicial da entidade.

Art. 27. Considera-se como o início do funcionamento da FUNPRESP a data correspondente a cento e vinte dias após a publicação da autorização de funcionamento concedida pelo órgão regulador e fiscalizador das entidades fechadas de previdência complementar.

Art. 28. Aplicam-se ao regime de previdência complementar a que se referem os $\S \S 14,15$ e 16 do art. 40 da Constituição as disposições da Lei Complementar $n^{\circ} 108$, de 2001, e, no que com esta não colidir, da Lei Complementar $n^{\circ}$ 109 , de 2001.

Art. 29. Até que seja promovida a contratação na forma prevista no $\S 3^{0}$ do art. 15 desta Lei, a totalidade dos recursos garantidores, provisões e fundos dos planos de benefícios da FUNPRESP será administrada, mediante remuneração compatível com os preços de mercado, por instituição financeira federal.

Art. 30. Esta Lei entra em vigor na data de sua publicação. 